\title{
Solid Phases and Solution Species of Different Elements in Geologic Environments
}

Dhanpat Rai

R. J. Serne

March 1978

Pacific Northwest Laboratory

Richland, Washington 99352

Operated for the

U.S. Department of Energy

by 


\title{
NOTICE
}

This report was prepared as an account of work sponsored by the United States Covernment. Neither the United States nor the Department of Energy, nor any of their employees, nor any of their contractors. subcontractors, or their employees, makes any warranty, express or implied, or assumes any legal tiability or responsibility for the accuracy, compieteness or usefuiness of any information, apparatus, product or process disclosed, or represents that its use would not iniringe privately owned rights.

The views, opinions and conclisions contained in this report are those of the contractor and co not necessarily represeni those of the United States Government or the United States Department of Energy.

\author{
FACIFIC NORTHWEST LABORATORY \\ operated by \\ BATTELLE \\ for the \\ LNITED STATES DEPARTMENT OF ENERGY
}

Under Contract EY-76-C-06-1830

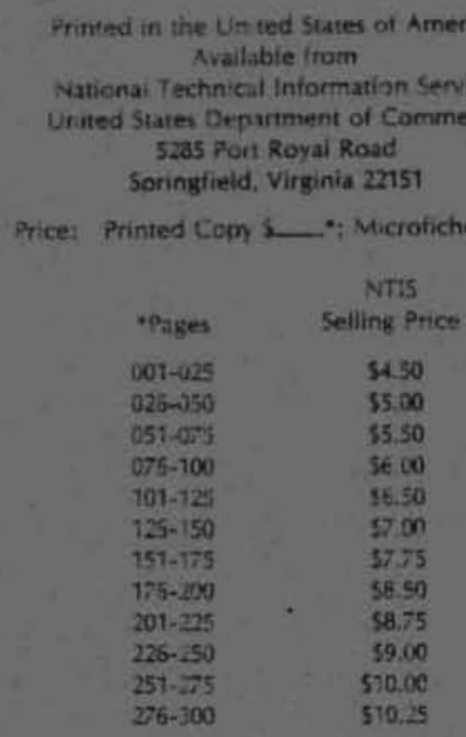


Dhanpat Rai

R. J. Serne

March 1978

PACIFIC NORTHWEST LABORATORY

Richland, Washington 99352

Operated for the

U.S. Department of Energy

By Battelle Memorial Institute 


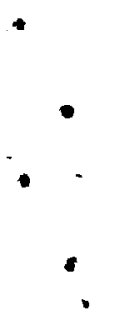

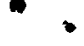
5 


\section{CONTENTS}

INTRODUCTION.

METHODS AND MATERIALS. . . . . . . . . . . . . . . . . 3

DATA COLLECTION . . . . . . . . . . . . . . . . . . . 3

LIMITATIONS OF THEORETICAL APPROACH • . . . . . . . . . 4

CONSTRUCTION AND INTERPRETATION OF THE DIAGRAMS . . . . . . 5

DISCUSSION OF SOLID PHASES AND SOLUTION SPECIES . . . . . . . . . . 11

AMERICIUM . . . . . . . . . . . . . . . . . . . 11

Predicted vs. Observed Behavior of Americium. . . . . . 15

ANTIMONY . . . . . . . . . . . . . . . . . . . . . 16

Predicted vs. Observed Behavior of Antimony . . . . . 20

CERIUM . . . . . . . . . . . . . . . . . . . 21

Predicted vs. Observed Behavior of Cerium. . . . . . 25

CESIUM . • . . . . . . . . . . . . . . . . . . 26

Predicted vs. Observed Behavior of Cesium. . . . . . 27

COBALT . . . . . . . . . . . . . . . . . . . . 28

Predicted vs. Observed Behavior of Cobalt. . . . . . 32

CURIUM . • . . . . . . . . . . . . . . . . .

Predicted vs. Observed Behavior of Curium. . . . . . 37

EUROPIUM • . . . . . . . . . . . . . . . . . . 38

Predicted vs. Observed Behavior of Europium . . . . . . 45

IODINE . . . . . . . . . . . . . . . . . . . . 46

Predicted vs. Observed Behavior of Iodine. . . . . . . 47

NEPTUNIUM . . . . . . . . . . . . . . . . . . 48

Predicted vs. Observed Behavior of Neptunium. . . . . . 52 


\section{CONTENTS}

PLUTONIUM . . . . . . . . . . . . . . . . . . 53

Predicted vs. Observed Behavior of Plutonium. . . . . . 63 PROMETHIUM. . . . . . . . . . . . . . . . . . 65

Predicted vs. Observed Behavior of Promethium . . . . . 67 RADIUM . . . . . . . . . . . . . . . . 68

Predicted vs. Observed Behavior of Radium. . . . . . . 69 RUTHENIUM . . . . . . . . . . . . . . . . . . 70

Predicted vs. Observed Behavior of Ruthenium. . . . . . 75 STRONTIUM . . . . . . . . . . . . . . . . . . . 76

Predicted vs. Observed Behavior of Strontium. . . . . . 80 TECHNETIUM. . . . . . . . . . . . . . . . . . 81

Predicted vs. Observed Behavior of Technetium . . . . . 82 THORIUM. . . . . . . . . . . . . . . . . . . . 83

Predicted vs. Observed Behavior of Thorium . . . . . 87 TRITIUM. . . . . . . . . . . . . . . . . . . . 88

Predicted vs. Observed Behavior of Tritium . . . . . . 89 URANIUM. . . . . . . . . . . . . . . . . . . . 90

Predicted vs. Observed Behavior of Uranium . . . . . . 95 ZIRCONIUM . . . . . . . . . . . . . . . . . 96

Predicted vs. Observed Behavior of Zirconium. . . . . . 101 SUMMARY AND CONCLUSIONS . . . . . . . . . . . . . . . 102 REFERENCES . . . . . . . . . . . . . . . . . . . 106 


\section{FIGURES}

1 Predicted Variation in $\mathrm{PuO}_{2}$ Solubility . . . . . . . . . 8

2 Comparison of Predicted vs. Observed $\mathrm{PuO}_{2}$ Solubility. . . . . 9

3 The Relative Stability of Various Americium Solids in an Oxidizing Environment $\left(\mathrm{pO}_{2}=0.68 \mathrm{~atm}\right) . . .9 . \quad . \quad .13$

4 The Activity of Various Americium Species in Equilibrium with $\mathrm{AmO}_{2}$ in an Oxidizing Soil Environment $\left[\mathrm{pO}_{2}(\mathrm{~g})=0.68\right.$ atm], $\mathrm{pSO}_{4}{ }^{2-}=\mathrm{pCl}^{-}=3.0$ and $\mathrm{pH}_{2} \mathrm{PO}_{4}-=5.0$. . . . . . . 14

5 The Activity of $\mathrm{SbO}^{+}$in Equilibrium with Various Antimony Solids in an Oxidizing Soil Solution Environment $\left[\mathrm{pO}_{2}(\mathrm{~g})=\right.$

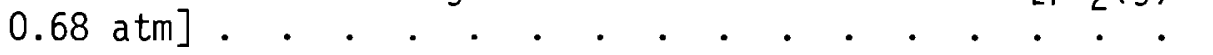

6 The Activity of Various Antimony Species in Equilibrium with $\mathrm{Sb}_{2} \mathrm{O}_{3}\left(\mathrm{~s}\right.$ ) (cubic) with $\mathrm{pNH}_{4}^{+}=3.0$ and $\mathrm{pF}^{-}=4.5$.

0xidation-reduction changes do not affect the concentration of species reports in this figure. . . . . . . .

7 The Activity of $\mathrm{Ce}^{3+}$ in Equilibrium with Phosphate Levels from Variscite and Gibbsite ( $V$ and $G$ ), Dicalcium Phosphate Dihydrate (DCPD) and Octacalcium Phosphate (OCP) . . . . . . 22

8 The Activity of Various Cerium Species in Equilibrium with $\mathrm{CePO}_{4}(\mathrm{~s})$ in an Oxidizing Soil Environment $\left[\mathrm{pO}_{2}(\mathrm{~g})=0.68\right.$ $\mathrm{atm}], \mathrm{pF}^{-}=4.5, \mathrm{pCl}^{-}=\mathrm{pSO}_{4}{ }^{2-}=2.5, \mathrm{pNO}_{3}^{-}=3.0$ and $\mathrm{pH}_{2} \mathrm{PO}_{4}=5.0$

9 The Relative Stability of Cobalt Solids in an 0xidizing Environment $\left[\mathrm{pO}_{2}(\mathrm{~g})=0.68 \mathrm{~atm}\right], \mathrm{pCa}^{2+}=2.5$ and Phosphate Levels in Equilibrium with Variscite and Gibbsite (V and G), Dicalcium and Phosphate Dihydrate (DCPD) and Octacalcium

Phosphate (OCP).

10 The Activity of Various Cobalt Ions in Equilibrium with $\mathrm{CoCO}_{3}(\mathrm{~s})$ in an Oxidizing Soi] Environment $\left[\mathrm{pO}_{2}(\mathrm{~g})=0.68\right.$ $\mathrm{atm}], \mathrm{pCO}_{2}(\mathrm{~g})=1.52 \mathrm{~atm}, \mathrm{pCl}-=\mathrm{pSO}_{4}^{2}=2.5, \mathrm{pNO}_{3}=3.0$ and $\mathrm{pH}_{2} \mathrm{PO}_{4-}=5.0$. . . . . . . . . . . . . . .

11 The Activity of Various Curium Ion Species in Equilibrium with $\mathrm{Cm}(\mathrm{OH})_{3}(\mathrm{~s})$ with $\mathrm{pF}^{-}=4.5, \mathrm{pCl}^{-}=\mathrm{pSO}_{4}{ }^{2-}=2.5, \mathrm{pNO}_{3}^{-}=$ 3.0 and $\mathrm{pH}_{2} \mathrm{PO}_{4}^{-}=5.0$. . . . . . . . . . . . . . 35

12 The Relative Stability of Various Europium Solids at $\mathrm{pSO}_{4}-=2.5$ 


\section{FIGURES}

13 The Activity of Various Europium Species in Equilibrium with $\mathrm{Eu}(\mathrm{OH})_{3}(\mathrm{~s})$. Other conditions include $\mathrm{pSO}_{4}^{-}=\mathrm{pCl}^{-}=$ 2.5, $\mathrm{pNO}_{\overline{3}}=3.0, \mathrm{pF}^{-}=4.5$ and phosphate levels in equilibrium with variscite and gibbsite ( $V$ and $G$ ), dicalcium phosphate dihydrate (DCPD), and octacalcium phosphate (OCP) . 42

14 The Influence of $\mathrm{pH}$ on the Activity of Europium in Solution (Serne and Rai, 1976, Unpublished data) . . . . . . . . 43

15 The Relative Stability of Various Neptunium Solids in an Oxidizing Soil Environment $\left[\mathrm{pO}_{2}(\mathrm{~g})=0.68 \mathrm{~atm}\right] . .+. \quad . \quad . \quad 50$

16 The Activity of Various Neptunium Species in Equilibrium with $\mathrm{NpO}_{2}(\mathrm{~s})$ under $\mathrm{pO}_{2}=0.68, \mathrm{pCl}^{-}=\mathrm{pSO}_{4}^{2-}=2.5, \mathrm{pNO}_{3}^{-}=$ $3.0, \mathrm{pF}^{-}=4.5$ and $\mathrm{pH}_{2}^{2} \mathrm{PO}_{4}^{-}=5.0$.

17 The Relative Stability of Plutonium Solids Under $\mathrm{pO}_{2}=$ $0.68, \mathrm{pCO}_{2}=3.52, \mathrm{pF}^{-}=3.5$ and Phosphate Levels in Equilibrium with Variscite and Gibbsite ( $V$ and $G$ ), Dicalcium Phosphate Dihydrate (DCPD) and Octacalcium Phosphate (OCP) (Rai and Serne, 1977). . . . . . . . .

18 The Relative Stability of Various Plutonium Solids in Reducing Environments $\left(\mathrm{pO}_{2}=80\right), \mathrm{pCO}_{2}=3.52, \mathrm{pF}^{-}=3.5$, and Phosphate Levels in Equilibrium with Variscite and Gibbsite ( $V$ and $G$ ), Dicalcium Phosphate Dihydrate (DCPD) and Octacalcium Phosphate (OCP) (Rai and Serne, 1977)

19 The Activity of Various Plutonium Species in Equilibrium with $\mathrm{PuO}_{2}(\mathrm{~s})$ Under $\mathrm{pO}_{2}=16, \mathrm{pCO}_{2}=3.52, \mathrm{pCl}^{-}=2.5$, $\mathrm{pF}^{-}=3.5$, and $\mathrm{pH}_{2} \mathrm{PO}_{4}^{-}=5.0(\mathrm{Ra} i$ and Serne, 1977). .

20 The Activity of Various Plutonium Species in Equilibrium with $\mathrm{PuO}_{2}(\mathrm{~s})$ at $\mathrm{pH} 8, \mathrm{pCO}_{2}=3.52, \mathrm{pCl}^{-}=\mathrm{pSO}_{4}^{2}=2.5$, and $\mathrm{pH}_{2} \mathrm{PO}_{4}^{-}=5.0$ (Rai and Serne, 1977). . . . . . . . . . 62

21 The Relative Stability of Various Promethium Solids . . • • . 66

22 The Relative Stability of Various Ruthenium Solids in an Oxidizing Soil Environment $\left[\mathrm{pO}_{2}(\mathrm{~g})=0.68 \mathrm{~atm}\right]$, $\mathrm{pC}^{-}=\mathrm{pSO}_{4}{ }^{-}=2.5$.

23 The Activity of Various Ruthenium Species in Equilibrium with $\mathrm{RuO}_{2}$ (Amorphous Hydrate) in an Oxidizing Soil Environment $\left[\mathrm{pO}_{2}(\mathrm{~g})=0.68 \mathrm{~atm}\right], \mathrm{pCl}^{-}=2.5$. 


\section{FIGURES}

24 The Relative Stability of Strontium Solids at $\mathrm{pCa}^{2+}=$ $\mathrm{pSO}_{4}^{2-}=2.5, \mathrm{pH}_{4} \mathrm{SiO}_{4}=3.1, \mathrm{pCO}_{2}=1.52$ and Phosphate Levels in Equilibrium with Variscite and Gibbsite (V and $G$ ), Dicalcium Phosphate Dihydrate (DCPD), and Octacalcium

Phosphate (OCP) . . . . . . . . . . . . . . . .

25 The Activities of Various Stront: um Species in Equilibrium with $\mathrm{SrCO}_{3}(\mathrm{~s})$ in the Soil at $\mathrm{pC}^{-}=\mathrm{pSO}_{4}^{-}=2.5, \mathrm{pNO}_{3}^{-}=3.0$, $\mathrm{pF}^{-}=4.5, \mathrm{pCO}_{2}=1.52$ and $\mathrm{pH}_{2} \mathrm{PO}_{4}^{-}=5.0^{4}$.

26 The Relative Stability of Various Thorium Solids in Equilibrium with Variscite and Gibbsite (V and G), Dicalcium Phosphate Dihydrate (DCPD).

27 Activity of Various Thorium Species in Equilibrium with $\mathrm{ThO}_{2}(\mathrm{~s}), \mathrm{pCl}^{-}=\mathrm{pNO}_{3}^{-}=\mathrm{pSO}_{4}^{-}=3.0, \mathrm{pF}^{-}=4.5$ and $\mathrm{pH}_{2} \mathrm{PO}_{4}^{-}=$ 5.0

28 The Relative Stability of Various Solids in an Oxidizing Environment $\left[\mathrm{pO}_{2}=0.68\right], \mathrm{pCO}_{2}=3.52, \mathrm{pK}^{+}=\mathrm{pNa}^{+}=3.0$ and Phosphate Levels in Equilibrium with Variscite and Gibbsite . .

29 Acivity of Various Uranium Species in Equilibrium with $\mathrm{Na}_{4}$ in Oxidizing Soil Environment $\left(\mathrm{pO}_{2}=0.68\right), \mathrm{pCO}_{2}=$ $3.5 \ddot{c}, \mathrm{pCl}^{-}=\mathrm{pSO}_{4}^{-}=3.0, \mathrm{pF}^{-}=4.5$ and $\mathrm{pH}_{2} \mathrm{PO}_{4}^{-}=5.0$.

30 The Stability of Zirconium Solids in Equilibrium with Soil Silica $\left(\mathrm{pH}_{4} \mathrm{SiO}_{4}=3.1\right)$. . . . . . . . . . . . . 99

31 The Activity of Various Zirconium Species in Equilibrium with Soil Silica $\left(\mathrm{pH}_{4} \mathrm{SiO}_{4}=3.1\right)$ and at $\mathrm{pC}^{-}=\mathrm{pSO}_{4}^{-}=2.5$, $\mathrm{pNO}_{3}^{-}=3.0, \mathrm{pF}^{-}=4.5$. . 


\section{TABLES}

1 Gibbs Free Energy of Formation $\left(\Delta G_{f}^{\circ}\right)$ for Some Pu Species . . . $\quad i$

2 Additional Equilibrium Constants $\left(K^{\circ}\right)$ at $25^{\circ} \mathrm{C}$ and One Atmosphere Pressure Required to Construct the Diagrams

in the Report.

3 Selected Equilibrium Constants (K) at $25^{\circ} \mathrm{C}$ and One Atmosphere Pressure for Reactions Involving Americium . . . . 12

4 Selected Equilibrium Constants (K) at $25^{\circ} \mathrm{C}$ and One Atmosphere Pressure for Reactions Involving Antimony. . . . . 17

5 Selected Equilibrium Constants (K) at $25^{\circ} \mathrm{C}$ and One Atmosphere Pressure for Reactions Involving Cerium . . . . . 23

6 Selected Equilibrium Constants (K) at $25^{\circ} \mathrm{C}$ and One Atmosphere Pressure For Reactions Involving Cobalt . . . . . 29

7 Selected Equilibrium Constants (K) at $25^{\circ} \mathrm{C}$ and One Atmosphere Pressure for Reactions Involving Curium . . . . . 36

8 Selected Equilibrium Constants (K) at $25^{\circ} \mathrm{C}$ and One Atmosphere Pressure for Reactions Involving Europium. . . . . 41

9 Effect of $\mathrm{pH}$ and Europium Concentration on Europium Kd by Burbank Sand $(a)$ (Serne and Rai, 1976). . . . . . . . . 44

10 Selected Equilibrium Constants (K) at $25^{\circ} \mathrm{C}$ and One Atmosphere Pressure for Reactions Involving Neptunium . . . . 49

11 Selected Equilibrium Constants (K) at $25^{\circ} \mathrm{C}$ and One Atmosphere Pressure for Reactions Involving Plutonium . . . . 57

12 Selected Equilibrium Constants (K) at $25^{\circ} \mathrm{C}$ and One Atmosphere Pressure for Reactions Involving Ruthenium . . . . 73

13 Selected Equilibrium Constants $(K)$ at $25^{\circ} \mathrm{C}$ and One Atmosphere Pressure for Reactions Involving Strontium . . . . 77

14 Selected Equilibrium Constants (K) at $25^{\circ} \mathrm{C}$ and One Atmosphere Pressure for Reactions Involving Thorium . . . . . 85

15 Selected Equilibrium Constants (K) at $25^{\circ} \mathrm{C}$ and One Atmosphere Pressure for Reactions Involving Uranium . . . . . 91 


\section{TABLES}

- $\quad 16$ Selected Equilibrium Constants (K) at $25^{\circ} \mathrm{C}$ and One Atmosphere Pressure for Reactions Involving Zirconium . . . . 98

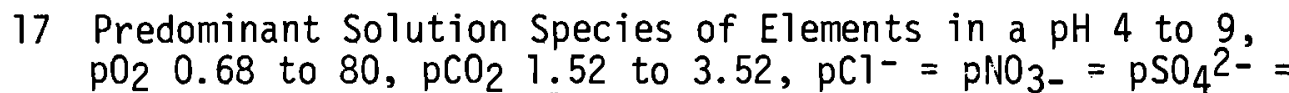
$3.0, \mathrm{pF}^{-} 4.5$ and $\mathrm{pH}_{2} \mathrm{PO}_{4}^{-} 5.0$ Environment Without Organic Ligands. 
- 
SOLID PHASES AND SOLUTION SPECIES OF

DIFFERENT ELEMENTS IN GEOLOGIC ENVIRONMENTS

\section{INTRODUCTION}

Among factors that influence radionuclide behavior in the environment, the nature of the solid phases and solution species of the radionuclide is one of the most important. Through their precipitation and dissolution, solid phases would cause changes in solution concentration which, in turn, would affect adsorbed ions. The environmental occurrence of most radionuclides is expected to be low so that discrete solid phases of the element may not be present in the terrestrial environment. In this case the element may be distributed throughout the soil and rock matrix and adsorption reactions may control solution concentrations. However, if the concentration of the element in solution is such that a solid phase of the element can precipitate, the knowledge of this solid phase and solution ions would help in predicting the solution concentrations available for transport (Dutt, Shaffer, and Moore, 1972; Jurinak and Medrano, 1974; Rai and Franklin, 1973; Tanji and Doneen, 1966). Granted the importance of the total solution concentrations of the element, the nature of the predominant solution species are important since they affect 1) charge dependent ion exchange; 2) adsorption because of changes in the nature of the species due to alteration of solution properties such as $\mathrm{pH}$, Eh, competing ions and complexing ions; 3) movement through the soil and rock matrix because of their physical size; and 4) plant uptake. The objectives of this report are:

1) to predict from thermodynamic data the nature of the solid phases and solution species in various weathering environments of different elements (Am, Sb, Ce, Cs, Co, Cm, Eu, I, Np, Pu, Pm, Ra, Ru, Sr, Tc, T, U, Zr) that are present in radioactive wastes

2) to predict the degree of adsorption of different elements by the solid matrices and to compare these predictions with observed results

(a) This study was done for the Department of Energy under a WISAP program. 
3) to determine the influence of different factors (such as pH, Eh, complexing ligands) on total pore-water concentration and the nature of solution species of selected elements

The diagrams used in this document were constructed on an EPA sponsored program to criticaliy assess the available literature on radionuclide migration in geologic materials. The EPA program will result in the publication of a two volume report which wi11 be published in the first half of 1978 (Ames, 1978; Ames and Rai, 1978). As the EPA program was underway when this related DOE task was formulated, a decision was made to utilize the EPA funded material rather than performing separate but duplicative work. 


\section{METHODS AND MATERIALS}

Laboratory information on possible solid phase and solution species of elements of interest in radioactive waste is almost nonexistent (Ames and Rai, 1978). What little information is available is very site and solution specific with such poorly defined system variables that no few extrapolations can be made to other situations. In order to bridge this gap, thermodynamic data are generally used to construct Eh-pH diagrams to predict stable phases and solution species (Pourbaix, 1966; Garrels and Christ, 1965). This approach also has several limitations, but is the best method until extensive laboratory data become available.

\section{DATA COLLECTION}

The laboratory information regarding the solid phases and solution species and the adsorption of different elements by the geologic media was selected from a comprehensive literature review which is underway concurrently with this study (Ames, 1978; Ames and Rai, 1978).

In order to develop solid phase-solution species diagrams, accurate values of the equilibrium constants of all the reactants and products are required. Equilibrium constants were selected from several readily available sources, the most important of these sources being Sillen and Martell (1964); NBS publications (Rossini et a1., 1952; Wagman et a1., 1968, 1969, 1971; Parker et a1., 1971; Schumm, 1973), Latimer (1952); Pourbaix (1966); Cleveland (1970); Keller (1971); Burney and Harbour (1974); and Baes and Mesmer (1976). The thermodynamic data were used to develop equilibrium constants for chemical equations that describe the behavior of various species. Generally these equations are used to develop Eh-pH diagrams (Pourbaix, 1966; Garrels and Christ, 1965) that provide the information regarding the stable compounds and solution species in the whole range of $\mathrm{pH}$ and Eh. However, Eh-pH diagrams can be used only for elements that exist in more than one oxidation state, and these diagrams do not indicate the total amount of the element and the relative amount of various species in solution under specified conditions. Therefore, activity-pH diagrams rather than Eh-pH diagrams were developed. 
The solid phase-solution species diagrams of elements affected by oxidationreduction were developed at an assumed partial pressure of oxygen (0.2 atmospheres in most cases). However, the changes in solution concentration or the stability of the solid phases that would occur due to the decrease in oxygen pressures are also discussed. This approach is similar to the one used by Lindsay (1972), Baes and Mesmer (1976), and Rai and Serne (1977).

\section{LIMITATIONS OF THEORETICAL APPROACH}

Using theromodynamic data to predict the stable solid phases and the concentration and nature of species in different environments is a powerful approach. The major limitation lies not in the approach but in the paucity and the accuracy of the available thermodynamic data. Some other limitations are 1) no consideration of the kinetics of reactions; and 2) the predictions apply only under equilibrium conditions.

Selected thermodynamic data were made internally consistent. These data were then used to estimate solid phases and solution species equilibria. It should be pointed out that in most cases there are large variations in the equilibrium constants reported by different authors (especially for actinides). It is very difficult to determine the accuracy of these constants without actually redoing the experiments. A rigorous selection process may help determine accurate values, but for this report the most recent data were selected.

The theoretical predictions outlined in this report regarding the relative 1) stability and dissolution of different solid phases; 2) abundance of different solution species; and 3 ) changes in total concentration and the nature of species of an element with changes in solution properties (such as $\mathrm{pH}$, Eh, $\mathrm{CO}_{2}$ pressure, concentration of various cations and anions) can be considered fairly reliable. However, the absolute concentration of an element in solution, in equilibrium with different solid phases and environmental conditions should be considered questionable, because of the uncertainities in the accuracy of the thermodynamic data. In order to further illustrate this statement an example of plutonium equilibria is given below. 
Rai and Serne (1977) predicted 1) $\mathrm{PuO}_{2}$ followed by $\mathrm{Pu}(\mathrm{OH})_{4}$ to be the most stable solid phases of the Pu compounds for which data are available; 2) the total concentration of $\mathrm{Pu}$ in acidic-oxidizing solutions in equilibrium with these compounds can be approximated by the concentrations of $\mathrm{PuO}_{2}^{+}$and $\mathrm{PuO}_{2}^{2+}$; and 3 ) the concentration of $\mathrm{Pu}$ in acidic-oxidizing solutions in equilibrium with $\mathrm{PuO}_{2}$ or $\mathrm{Pu}_{0}(\mathrm{OH})_{4}$ would decrease with the increase in $\mathrm{pH}$. Using the most reliable $\Delta G_{f}$ values available in the literature for (Table 1 ), the concentration of $\mathrm{PuO}_{2}^{+}$and $\mathrm{PuO}_{2}^{2+}$ in equilibrium with $\mathrm{PuO}_{2}$ is plotted in Figure 1 (dashed 1 ines).

When $\log \mathrm{K}_{\mathrm{s} 10}$ of $\mathrm{PuO}_{2}$ estimated by Baes and Mesmer (1976) is combined with $\triangle \mathrm{G}_{\mathrm{f}}^{\circ}$ of $\mathrm{PuO}_{2}^{+}$and $\mathrm{PuO}_{2}^{2+}$ in Table 1 , the $\mathrm{PuO}_{2}^{+}$and $\mathrm{PuO}_{2}^{2+}$ lines are approximately $2.3 \log$ units higher than the dashed lines (Figure 1). The cross hatched area in Figure 1 indicates the Pu concentration variation due to differences in thermodynamic data reported by various authors and due to the standard errors involved in the determination of various data. It can be seen from the Figure 1 that a variation in Pu concentration of approximately $5 \log$ units or 100,000 times can be expected at any given pH. Clearly, accurate predictions of $\mathrm{Pu}$ concentrations in equilibrium with $\mathrm{PuO}_{2}$ cannot be made from the above data. Rai, et al. (1977) have shown that the observed $\mathrm{Pu}$ concentrations in equilibrium with $\mathrm{PuO}_{2}$ under environmental $\mathrm{pH}$ and $\mathrm{Eh}$ values are higher than the highest predicted values (Figure 2). Variation of approximately 5 orders of magnitude in predicted Pu concentration in equilibrium with $\mathrm{Pu}(\mathrm{OH})_{4}$ is also observed when the thermodynamic data are plotted in a similar fashion to $\mathrm{PuO}_{2}$. Although there is an uncertainity about the absolute $\mathrm{Pu}$ concentrations in equilibrium with $\mathrm{PuO}_{2}$ and $\mathrm{Pu}(\mathrm{OH})_{4}$, the predicted relative solubility of $\mathrm{PuO}_{2}$ and $\mathrm{Pu}(\mathrm{OH})_{4}$ is the same as the observed relative solubility of these compounds (Rai, et al., 1977).

\section{CONSTRUCTION AND INTERPRETATION OF THE DIAGRAMS}

The details of the method of constructing the diagrams presented in this report can be found in Rai and Lindsay (1975) and Rai and Serne (1977). In these diagrams the $\mathrm{pCO}_{2}(\mathrm{~g}), \mathrm{pK}^{+}$, and $\mathrm{pNa}^{+}$, etc., refer to the negative 
logarithm of the activity (in moles/1 for solution species and atmospheres for gases). The oxidation-reduction conditions are denoted by partial pressures of oxygen.

In the solid phase diagrams, any compound that lies below another compound at a given $\mathrm{pH}$ is more stable. Thus, for any two solids at a specific pH, the solid that maintains lower ionic activity is more stable. In addition to stability, information regarding weathering and formation can also be obtained from these diagrams. If, in a given soi $\dot{i}$, the soil solution composition is below the solid line, the soil is under-saturated with respect to the solid represented by the line, and that mineral will dissolve or weather. On the other hand, if a soil solution concentration is above the solid stability line, the soil is supersaturated with respect to the mineral represented by the line, and the mineral should precipitate.

The solution species diagrams were developed assuming a given oxidationreduction environment, equilibrium with a given compound, and set ionic activities of various cations $\left(\mathrm{Ca}^{2+}, \mathrm{Na}^{+}, \mathrm{NH}_{4}^{+}\right)$and anions $\left(\mathrm{Cl}^{-}, \mathrm{HCO}_{3}^{-}, \mathrm{CO}_{3}{ }^{2-}\right.$, $\mathrm{NO}_{3}{ }^{-}, \mathrm{F}^{-}, \mathrm{SO}_{4}{ }^{2-}$, and $\mathrm{PO}_{4}{ }^{3-}$ ) that may be present in the terrestrial environment. Organic ligands and colloids that may be present in the solutions were not considered. The solution species diagrams depict anionic, cationic, and several neutral or uncharged species for which data were available.

The equilibrium constants involving specific elements of interest are reported under appropriate headings. Some of the additional reactions required to construct the diagrams presented in this report are given in Table 2. 


\section{TABLE 1. Gibbs Free Energy of Formation}

$\left(\Delta G_{f}^{\circ}\right)$ for Some Pu Species

\begin{tabular}{|c|c|c|}
\hline Species & $\Delta G_{f}^{\circ}(\mathrm{KCal} / \mathrm{mole})$ & Reference \\
\hline $\mathrm{PuO}_{2}$ & $-240.4 \pm 0.8$ & Holley et al. (1958) \\
\hline $\mathrm{Pu}^{4+}$ & $-115.1 \pm 0.8$ & Fuger and Oetting (1976) \\
\hline $\mathrm{PuO}_{2}^{+}$ & $-203.1 \pm 1.8$ & Fuger and Oetting (1976) \\
\hline $\mathrm{PuO}_{2}^{2+}$ & $-180.9 \pm 1.7$ & Fuger and 0etting (1976) \\
\hline
\end{tabular}




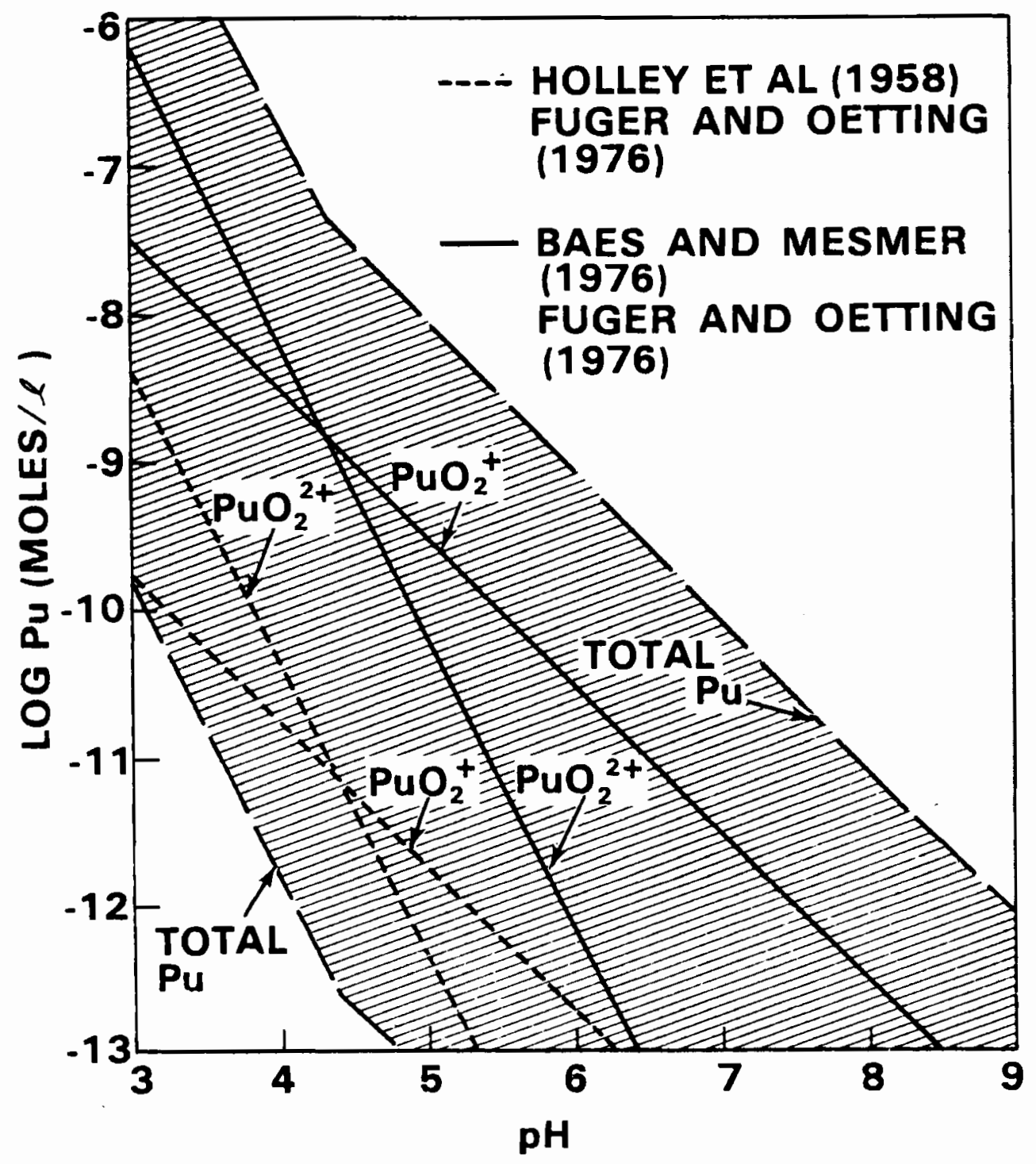

FIGURE 1. Variation in Predicted $\mathrm{PuO}_{2}$ Solubility 


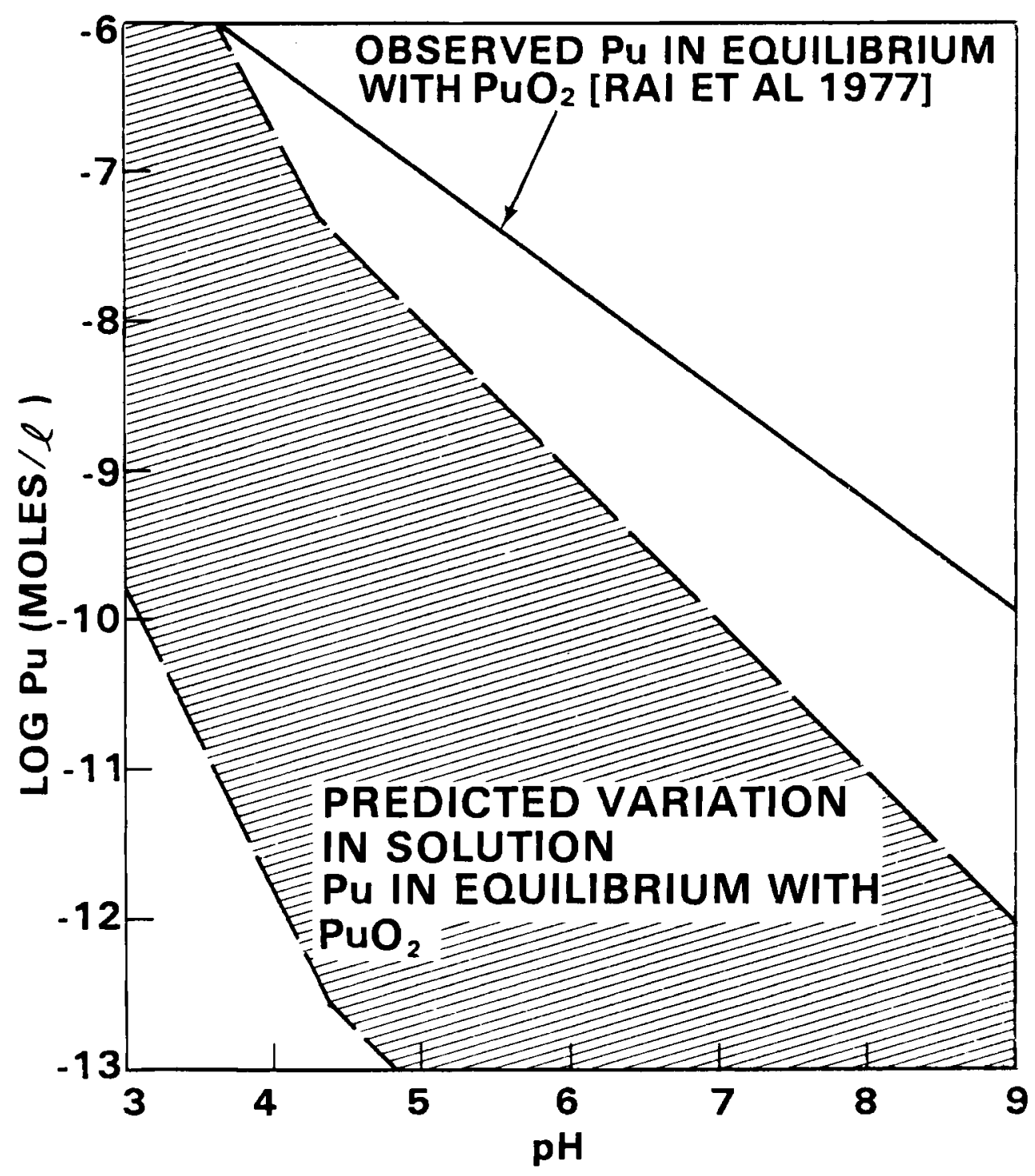

FIGURE 2. Comparison of Predicted vs. Observed $\mathrm{PuO}_{2}$ Solubility 
TABLE 2. Additional Equilibrium Constants $\left(K^{\circ}\right)$ at $25^{\circ} \mathrm{C}$ and One Atmosphere

\section{Reaction}

\begin{tabular}{|c|c|c|c|}
\hline \multicolumn{2}{|c|}{ Reaction } & \multirow{2}{*}{$\begin{array}{l}\underline{\log K^{\circ}} \\
-33.80\end{array}$} & Reference \\
\hline $\mathrm{Al}(\mathrm{OH})_{3}$ (gibbsite) & $\overrightarrow{+} \mathrm{Al}^{3+}+3 \mathrm{OH}^{-}$ & & Lindsay et a1. (1959) \\
\hline $\mathrm{CO}_{2}$ (gas) $+\mathrm{H}_{2} \mathrm{O}$ & $\rightleftarrows \mathrm{H}_{2} \mathrm{CO}_{3}$ & -1.46 & Sillen and Martel1 (1964) \\
\hline $\mathrm{H}_{2} \mathrm{CO}_{3}$ & $\underset{\mathrm{H}}{+}+\mathrm{HCO}_{3}^{-}$ & -6.35 & $"$ \\
\hline $\mathrm{HCO}_{3}^{-}$ & $\stackrel{+}{+} \mathrm{H}^{+}+\mathrm{CO}_{3}^{2-}$ & -10.33 & " \\
\hline $\mathrm{CaCO}_{3}$ (calcite) & 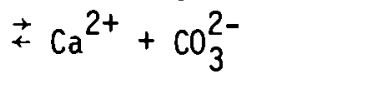 & -8.35 & $"$ \\
\hline $\mathrm{H}^{+}+\mathrm{Cl}^{-}$ & $\stackrel{\mathrm{HCl}}{ }$ & 4.05 & $"$ \\
\hline $\mathrm{HPO}_{4}^{2-}$ & $\vec{\leftarrow} \mathrm{H}^{+}+\mathrm{PO}_{4}^{3-}$ & -12.33 & $"$ \\
\hline $\mathrm{H}_{2} \mathrm{PO}_{4}^{-}$ & $\overrightarrow{\mathrm{HPO}_{4}^{2-}}+\mathrm{H}^{+}$ & -7.20 & $"$ \\
\hline $\mathrm{H}_{3} \mathrm{PO}_{4}$ & 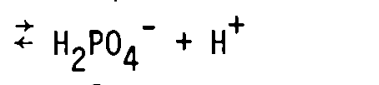 & -2.12 & $"$ \\
\hline $\mathrm{AlPO}_{4} 2 \mathrm{H}_{2} \mathrm{O}$ (variscite) & $\begin{aligned} \rightarrow & \mathrm{Al}^{3+}+\mathrm{H}_{2} \mathrm{PO}_{4}^{-} \\
& +2 \mathrm{H}^{-}\end{aligned}$ & -30.50 & $"$ \\
\hline $\begin{array}{l}\mathrm{CaHPO}_{2} 2 \mathrm{H}_{2} \mathrm{O} \text { (dicalcium } \\
\text { phosphate dihydrate) }\end{array}$ & $\begin{aligned} \rightarrow & \mathrm{Ca}^{2+}+\mathrm{HPO}_{4}^{2-} \\
& +2 \mathrm{H}_{2} \mathrm{O}\end{aligned}$ & -6.56 & $"$ \\
\hline $\begin{array}{l}\mathrm{Ca}_{4} \mathrm{H}\left(\mathrm{PO}_{4}\right)_{3} 3 \mathrm{H}_{2} \mathrm{O} \text { (octacalcium } \\
\text { phosphate) }\end{array}$ & $\begin{aligned} \rightleftarrows & 4 \mathrm{Ca}^{2+}+\mathrm{H}^{+}+3 \mathrm{PO}_{4}^{3-} \\
& +3 \mathrm{H}_{2} \mathrm{O}\end{aligned}$ & -46.90 & $"$ \\
\hline $\mathrm{HSO}_{4}^{-}$ & $\rightleftarrows \mathrm{H}^{+}+\mathrm{SO}_{4}^{2-}$ & -1.96 & $"$ \\
\hline $\mathrm{H}_{2} \mathrm{O}$ (water) & $\rightleftarrows \mathrm{H}^{+}+\mathrm{OH}^{-}$ & -14.00 & $"$ \\
\hline $\mathrm{H}_{2} \mathrm{O}$ (water) & $\begin{aligned} \rightleftarrows & 2 \mathrm{H}^{+}+1 / 2 \mathrm{O}_{2} \text { (gas) } \\
& +2 \mathrm{e}^{-}\end{aligned}$ & -41.55 & $"$ \\
\hline $\mathrm{SiO}_{2}(\mathrm{soi1})+2 \mathrm{H}_{2} \mathrm{O}$ & $\stackrel{+}{+} \mathrm{H}_{4} \mathrm{SiO}_{4}$ & -3.10 & $\begin{array}{l}\text { Elgawhary and Lindsay (1972); } \\
\text { and Helgeson (1969) }\end{array}$ \\
\hline
\end{tabular}

$\underline{\log K^{\circ}}$

\begin{tabular}{|c|c|c|c|}
\hline \multicolumn{2}{|c|}{ Reaction } & \multirow{2}{*}{$\begin{array}{l}\underline{\log K^{\circ}} \\
-33.80\end{array}$} & Reference \\
\hline $\mathrm{Al}(\mathrm{OH})_{3}$ (gibbsite) & $+\mathrm{Al}^{3+}+3 \mathrm{OH}^{-}$ & & Lindsay et al. (1959) \\
\hline $\mathrm{CO}_{2}$ (gas) $+\mathrm{H}_{2} \mathrm{O}$ & 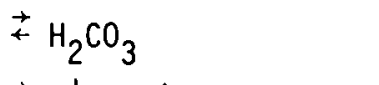 & -1.46 & Sillen and Martel1 (1964) \\
\hline $\mathrm{H}_{2} \mathrm{CO}_{3}$ & $\stackrel{+}{+}+\mathrm{HCO}_{3}^{-}$ & -6.35 & $"$ \\
\hline $\mathrm{HCO}_{3}^{-}$ & $\stackrel{+}{+} \mathrm{H}^{+}+\mathrm{CO}_{3}^{2-}$ & -10.33 & " \\
\hline $\mathrm{CaCO}_{3}$ (calcite) & 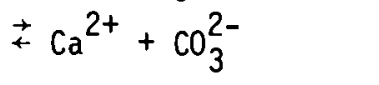 & -8.35 & " \\
\hline $\mathrm{H}^{+}+\mathrm{Cl}^{-}$ & $\rightleftarrows \mathrm{HCl}$ & 4.05 & $"$ \\
\hline $\mathrm{HPO}_{4}^{2-}$ & $\vec{\leftarrow} \mathrm{H}^{+}+\mathrm{PO}_{4}^{3-}$ & -12.33 & $"$ \\
\hline $\mathrm{H}_{2} \mathrm{PO}_{4}^{-}$ & $\rightarrow \mathrm{HPO}_{4}^{2-}+\mathrm{H}^{+}$ & -7.20 & $"$ \\
\hline $\mathrm{H}_{3} \mathrm{PO}_{4}$ & $\overrightarrow{+} \mathrm{H}_{2} \mathrm{PO}_{4}^{-}+\mathrm{H}^{+}$ & -2.12 & $"$ \\
\hline $\mathrm{AlPO}_{4} 2 \mathrm{H}_{2} \mathrm{O}$ (variscite) & $\begin{aligned} \rightarrow & \mathrm{Al}^{3+}+\mathrm{H}_{2} \mathrm{PO}_{4}^{-} \\
& +2 \mathrm{H}^{-}\end{aligned}$ & -30.50 & $"$ \\
\hline $\begin{array}{l}\mathrm{CaHPO}_{2} 2 \mathrm{H}_{2} \mathrm{O} \text { (dicalcium } \\
\text { phosphate dihydrate) }\end{array}$ & $\begin{aligned} \rightarrow & \mathrm{Ca}^{2+}+\mathrm{HPO}_{4}^{2-} \\
& +2 \mathrm{H}_{2} \mathrm{O}\end{aligned}$ & -6.56 & $"$ \\
\hline $\begin{array}{l}\mathrm{Ca}_{4} \mathrm{H}\left(\mathrm{PO}_{4}\right)_{3} 3 \mathrm{H}_{2} \mathrm{O} \text { (octacalcium } \\
\text { phosphate) }\end{array}$ & $\begin{aligned} \overrightarrow{+} & 4 \mathrm{Ca}^{2+}+\mathrm{H}^{+}+3 \mathrm{PO}_{4}^{3-} \\
& +3 \mathrm{H}_{2} \mathrm{O}\end{aligned}$ & -46.90 & $"$ \\
\hline $\mathrm{HSO}_{4}^{-}$ & $\rightleftarrows \mathrm{H}^{+}+\mathrm{SO}_{4}^{2-}$ & -1.96 & $"$ \\
\hline $\mathrm{H}_{2} \mathrm{O}$ (water) & $\stackrel{+}{+}+\mathrm{OH}^{-}$ & -14.00 & $"$ \\
\hline $\mathrm{H}_{2} \mathrm{O}$ (water) & $\begin{aligned}+ & 2 \mathrm{H}^{+}+1 / 2 \mathrm{O}_{2} \text { (gas) } \\
& +2 \mathrm{e}^{-}\end{aligned}$ & -41.55 & " \\
\hline $\mathrm{SiO}_{2}(\mathrm{soil})+2 \mathrm{H}_{2} \mathrm{O}$ & $\stackrel{+}{+} \mathrm{H}_{4} \mathrm{SiO}_{4}$ & -3.10 & $\begin{array}{l}\text { El gawhary and Lindsay (1972); } \\
\text { and Helgeson (1969) }\end{array}$ \\
\hline
\end{tabular}

\section{Pressure Required to Construct the Diagrams in the Report}


DISCUSSION OF SOLID PHASES AND SOLUTION SPECIES

\section{AMERICIUM}

Information regarding the possible solid phases of americium in soil and rock environments is lacking. However, the relative solubilities of several americium solids based upon estimated thermodynamic data (Table 3 ) are given in Figure 3 as a function of $\mathrm{pH}$. These are oxides and hydrous oxides of americium assumed to be present in an oxidizing environment $\left(\mathrm{pO}_{2}=\right.$ $0.68 \mathrm{~atm})$. The solubility of the solids decreases rapidly in the direction of increasing $\mathrm{pH}$. As the environment becomes less oxidizing, the activity of $\mathrm{Am}^{+3}$ associated with each of the solid phases [except $\mathrm{Am}(\mathrm{OH})_{3}$ ] increases rapidly. At $\mathrm{pO}_{2(\mathrm{~g})}=8.68 \mathrm{~atm}$, for example, the curve for $\mathrm{Am}^{3+}$ activity from $\mathrm{Am}(\mathrm{OH})_{4}(\mathrm{~s})$ increases by two log units.

The activity of various americium species in solution in equilibrium with $\mathrm{AmO}_{2}(\mathrm{~s})$ in an oxidizing environment $\left(\mathrm{pO}_{2}=0.68 \mathrm{~atm}\right)$ is given in Figure 4. The thermodynamic data used to construct Figure 4 are reported in Table 3. In the normal soil pH range, the complex species $A m(O H)^{2+}$ and $\mathrm{AmSO}_{4}{ }^{+}$would control the total activity of americium, with $\mathrm{Am}^{3+}$ of somewhat lesser importance. In the environmental conditions chosen, chloride, nitrate and phosphorus species were relatively unimportant in terms of the total americium present in solution. However it should be kept in mind that in a relatively high chloride environment, the $\mathrm{AmCl}^{2+}$, for example, could become the principal americium species in solution. With an increase in $\mathrm{pO}_{2}$ (more reducing environment) and the concentration of anions, the curves given in Figure 4 would move upwards. However, the relative position of most of the isotherms would not change. The americium species are all cationic in the normal soil pH range of from 4 to 8 . It is to be expected, therefore, that ion exchange could be an important americium removal mechanism. 
TABLE 3. Selected Equilibrium Constants $(K)$ at $25^{\circ} \mathrm{C}$ and One Atmosphere Pressure for Reactions Involving Americium

\begin{tabular}{|c|c|c|c|c|}
\hline \multicolumn{2}{|c|}{ Reaction } & Medium (a) & $\log K$ & Reference \\
\hline \multicolumn{5}{|c|}{ Solid Compounds } \\
\hline $\mathrm{Am}(\mathrm{OH})_{3}$ & $\rightleftarrows \mathrm{Am}^{3+}+30 \mathrm{H}^{-}$ & 0 & -19.57 & Latimer (1952) \\
\hline $\mathrm{Am}(\mathrm{OH})_{4}$ & $\rightarrow \mathrm{Am}^{4+}+40 \mathrm{H}^{-}$ & $1.0 \mathrm{OH}^{-}$ & -52.12 & $\operatorname{Keller}(1971)$ \\
\hline $\mathrm{AmO}_{2} \mathrm{OH}$ & $\rightarrow \mathrm{AmO}_{2}^{+}+\mathrm{OH}^{-}$ & $1.0 \mathrm{OH}^{-}$ & -33.29 & 1 \\
\hline $\mathrm{AmO}_{2}(\mathrm{OH})_{2}$ & $\rightleftarrows \mathrm{AmO}_{2}{ }^{2+}+2 \mathrm{OH}^{-}$ & $1.0 \mathrm{OH}^{-}$ & -41.69 & $"$ \\
\hline $\mathrm{AmO}_{2}+4 \mathrm{H}^{+}$ & $\rightleftarrows \mathrm{Am}^{4+}+2 \mathrm{H}_{2} \mathrm{O}$ & 0 & -6.23 & Latimer (1952) \\
\hline $\mathrm{AmF}_{3}$ & 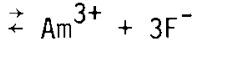 & Var. $(0.1-0.5)$ & -15.11 & $\begin{array}{l}\text { Keller }(1971) \text {; Sillen } \\
\text { and Martel1 (i964) }\end{array}$ \\
\hline
\end{tabular}

0xidation-Reduction Reactions

\begin{tabular}{|c|c|c|c|c|}
\hline $\mathrm{Am}^{2+}+2 \mathrm{e}^{-}$ & $\rightleftarrows \operatorname{Am}(s)$ & $1.0 \mathrm{HClO}_{4}$ & -91.29 & Keller (1971) \\
\hline $\mathrm{Am}^{3+}+3 \mathrm{e}^{-}$ & $\stackrel{A m}{ }(\mathrm{~s})$ & 0 & -121.0 & Sillen and Martell (1964) \\
\hline $\mathrm{Am}^{4+}+\mathrm{e}^{-}$ & $\rightleftarrows \mathrm{Am}^{3+}$ & 0 & 41.0 & $"$ \\
\hline $\mathrm{AmO}_{2}^{+}+4 \mathrm{H}^{+}+\mathrm{e}^{-}$ & $\rightleftarrows \mathrm{Am}^{4+}+2 \mathrm{H}_{2} \mathrm{O}$ & 0 & 21.0 & $"$ \\
\hline $\mathrm{AmO}_{2}^{2+}+e^{-}$ & $\stackrel{\mathrm{AmO}_{2}}{+}$ & 0 & 27.0 & $"$ \\
\hline
\end{tabular}

Other Reactions

\begin{tabular}{|c|c|c|c|c|}
\hline $\mathrm{Am}^{3+}+\mathrm{H}_{2} \mathrm{O}$ & $\rightarrow \mathrm{AmOH}^{2+}+\mathrm{H}^{+}$ & 0.1 at $23^{\circ} \mathrm{C}$ & -5.92 & Keller (1971) \\
\hline $\mathrm{Am}^{3+}+\mathrm{Cl}^{-}$ & $\stackrel{\mathrm{AmCl}^{2+}}{2+}$ & 0 & 1.17 & Sillen and Martell (1964) \\
\hline $\mathrm{Am}^{3+}+\mathrm{F}^{-}$ & $\vec{\leftarrow} \mathrm{AmF}^{2+}$ & 0.5 & 3.39 & Keller (1971) \\
\hline $\mathrm{Am}^{3+}+2 \mathrm{~F}^{-}$ & $\vec{\leftarrow} \mathrm{AmF}_{2}+$ & 0.5 & 6.11 & $"$ \\
\hline $\mathrm{AmF}_{2}^{+}+\mathrm{F}^{-}$ & $\overrightarrow{\mathrm{AmF}_{3}^{\circ}}$ & $0.1\left(\mathrm{HClO}_{4}\right)$ at $23^{\circ} \mathrm{C}$ & 4.13 & Sillen and Martell (1964) \\
\hline $\mathrm{Am}^{3+}+\mathrm{NO}_{3}^{-}$ & $\vec{\leftarrow} \mathrm{AmNO}_{3}{ }^{2+}$ & $1.0 \mathrm{H}\left(\mathrm{ClO}_{4}\right)$ & 0.26 & $"$ \\
\hline $\mathrm{Am}^{3+}+\mathrm{H}_{2} \mathrm{PO}_{4}^{-}$ & $\rightarrow \mathrm{AmH}_{2} \mathrm{PO}_{4}^{2+}$ & 0 & 2.51 & Keller (1971) \\
\hline $\mathrm{Am}^{3+}+\mathrm{SO}_{4}^{2-}$ & $\stackrel{+}{\leftarrow} \mathrm{AmSO}_{4}^{+}$ & 0 & 3.68 & Sillen and Martell (1964) \\
\hline $\mathrm{AmSO}_{4}{ }^{+}+\mathrm{SO}_{4}{ }^{2-}$ & $\rightleftarrows \mathrm{Am}\left(\mathrm{SO}_{4}\right)_{2}^{-}$ & 1.5 & 0.35 & $"$ \\
\hline
\end{tabular}

(a) The nature of the medium to which the equilibrium constants refer, for example, 0 - zero ionic strength, var - ionic medium varied, $2\left(\mathrm{HClO}_{4}\right)$ - ionic strength held constant at the value stated ( 2 moles/lliter) by the addition of the chemical shown in parentheses, 1.0 $\mathrm{HClO}_{4}$ - constant concentration of the substance stated $\left(1.0\right.$ moles/2.1iter $\left.\mathrm{HC}_{4}\right)$. 


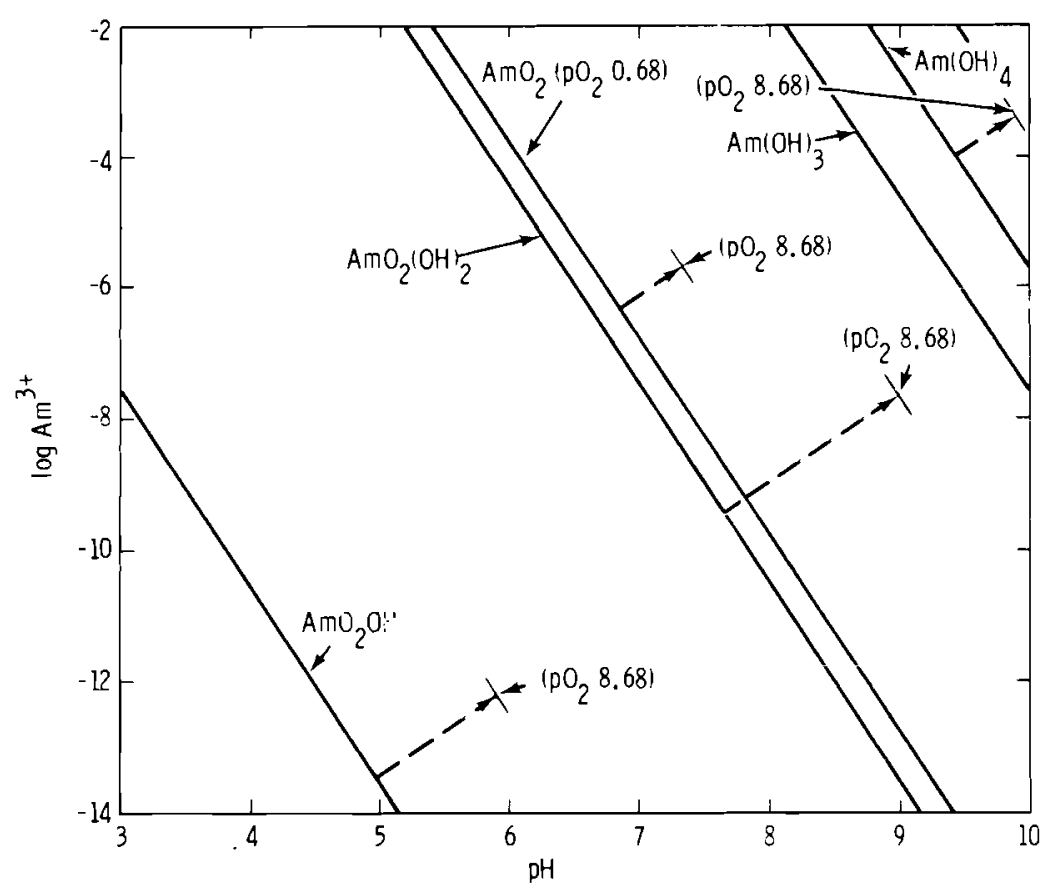

FIGURE 3. The Relative Stability of Various Americium Solids in an Oxidizing Environment $\left(\mathrm{pO}_{2}=\right.$ $0.68 \mathrm{~atm}$ ) 


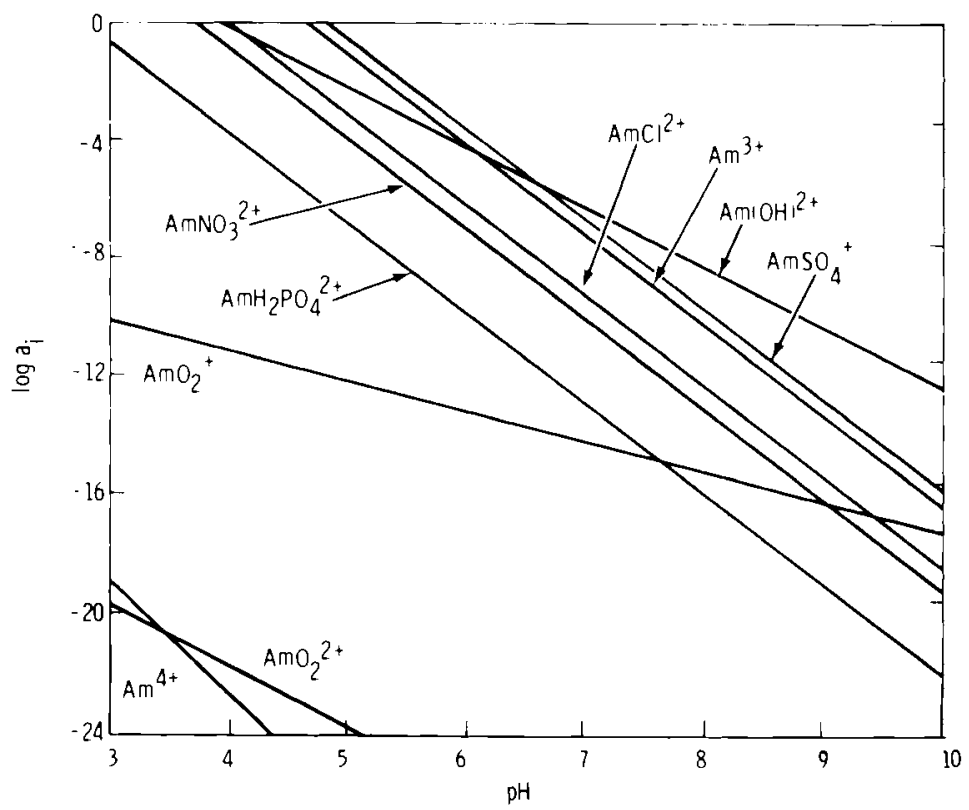

FIGURE 4. The Activity of Various Americium Species in Equilibrium with $\mathrm{AmO}_{2}$ in an Oxidizing Soi 1 Environment $\left[\mathrm{pO}_{2}(\mathrm{~g})=\right.$ $0.68 \mathrm{~atm}], \mathrm{pSO}_{4}^{2-}=\mathrm{pCl}^{-}=3.0$ and $\mathrm{pH}_{2} \mathrm{PO}_{4}^{-}=5.0$ 
PREDICTED VS. OBSERVED BEHAVIOR OF AMERICIUM

Information regarding the possible solid phases of americium in soil and rock environments is lacking.

It can be seen from Figure 4 that the predominant solution species of americium are all cationic, thus americium would be expected to enter into exchange reactions with soil minerals. This prediction is supported by the laboratory results. Americium adsorption (Kd values) on various soils and rocks have been correlated with 1) cation exchange capacity of soils (Sheppard, Kittrick and Hart, 1976; Glover, Miner, and Polzer, 1977), and 2) the concentration of the competing cations $\left(\mathrm{Na}^{+}, \mathrm{Ca}^{2+}, \mathrm{Sr}^{2+}, \mathrm{La}^{3+}\right.$ and $\left.\mathrm{Zr}^{4+}\right)$ so that the adsorption of americium decreases with an increase in concentration of competing cations (Fried, Friedman and Quarterman, 1974; Fried, Friedman and Weeber, 1974; Routson, Jansen and Robinson, 1975; Sheppard, Kittrick and Hart, 1976; Fried, 1977). Although none of the workers have tried to distinguish the contributions of polymer adsorption, cation exchange, hydrolysis and precipitation to the $\mathrm{Kd}$ value, the laboratory data indicate that americium removal from solution may be predominantly via an ion exchange mechanism. 


\section{ANTIMONY}

The selected thermodynamic data for various antimony solids are reported in Table 4 and are plotted in Figure 5 to determine the relative stability of these solid phases. This figure represents a highly oxidizing environment $\left(\mathrm{O}_{2}=10^{-0.68}\right)$. Under these conditions $\mathrm{SbCl}_{3}, \mathrm{SbF}_{3}$, and $\mathrm{Sb}_{2} \mathrm{~S}_{3}$ are very soluble and therefore are not shown in the figure.

Under these oxidizing conditions $\left(\mathrm{O}_{2}=10^{-0.68} \mathrm{~atm}\right)$ the minerals in increasing order of stability throughout the $\mathrm{pH}$ range can be arranged as follows: orthorhombic $\mathrm{Sb}_{2} \mathrm{O}_{3}$, cubic $\mathrm{Sb}_{2} \mathrm{O}_{3}$, orthorhombic $\mathrm{Sb}_{4} \mathrm{O}_{6}$, cubic $\mathrm{Sb}_{4} \mathrm{O}_{6}, \mathrm{Sb}(\mathrm{OH})_{3}$, $\mathrm{Sb}_{2} \mathrm{O}_{4}$, and $\mathrm{Sb}_{2} \mathrm{O}_{5}$. Solids containing antimony in a +5 state $\left(\mathrm{Sb}_{2} \mathrm{O}_{5}\right.$ and $\left.\mathrm{Sb}_{2} \mathrm{O}_{4}\right)$ and the $\mathrm{Sb}_{2} \mathrm{~S}_{3}$ would change their relative positions with changes in the oxidation-reduction conditions, whereas the other solids will retain their relative positions. $\mathrm{Sb}_{2} \mathrm{O}_{5}$ and $\mathrm{Sb}_{2} \mathrm{O}_{4}$ will become less stable with an increase in reducing conditions, while $\mathrm{Sb}_{2} \mathrm{~S}_{3}$ will become the most stable solid phase in extremely reducing conditions. $\mathrm{Sb}_{2} \mathrm{~S}_{3}$ is very soluble in an oxidizing environment because of the oxidation of sulfur to sulfate, which is the stable solution species (Garrels and Christ, 1965). Under extremely reducing conditions and total sulfur levels of approximately $10^{-3} \mathrm{M}$ where the dominant sulfur species is no longer the $\mathrm{SO}_{4}{ }^{2-}$, the most stable mineral will be $\mathrm{Sb}_{2} \mathrm{~S}_{3}$. In oxidation-reduction conditions corresponding to oxygen pressures of $<10-35$ atmospheres, $\mathrm{Sb}(\mathrm{OH})_{3}$ would be the most stable solid.

The selected thermodynamic data for solution species is reported in Table 4. The relative activity of various solution species in equilibrium with $\mathrm{Sb}_{2} \mathrm{O}_{3}(\mathrm{~s})$ is given in Figure 6 . If equilibrium with $\mathrm{Sb}(\mathrm{OH})_{3}(\mathrm{~s})$ is assumed, the activity of all the species would be approximately $2.9 \mathrm{log}$ units lower with the lines still parallel to the lines given in Figure 4. In the environmental $\mathrm{pH}$ range of interest ( 4 to 8 ), it can be seen that $\mathrm{HSbO}_{2}{ }^{\circ}$ and $\mathrm{Sb}(\mathrm{OH})_{3}^{\circ}$ are the species that would govern the total activity of antimony present in solution. The other species $\left[\mathrm{SbOF}^{\circ}, \mathrm{Sb}(\mathrm{OH})_{2}^{+}, \mathrm{SbO}^{+}\right.$, $\mathrm{Sb}(\mathrm{OH})_{4}^{-}$or $\mathrm{SbO}_{2}^{-}$and $\mathrm{NH}_{4} \mathrm{SbO}_{2}{ }^{\circ}$ ] do not contribute significantly to the total antimony present in the solution and hence can be ignored. Since the predominant solution species $\left[\mathrm{HSbO}_{2}{ }^{\circ}, \mathrm{Sb}(\mathrm{OH})_{3}^{\circ}\right.$ ] are neutral, ion exchange as an antimony adsorption mechanism is not expected to be important. 


\section{TABLE 4. Selected Equilibrium Constants (K) at $25^{\circ} \mathrm{C}$ and One Atmosphere} Pressure for Reactions Involving Antimony

$\mathrm{Sb}_{2} \mathrm{O}_{3}$ (cubic) $+2 \mathrm{H}$

$\geq 2 \mathrm{SbO}^{+}+\mathrm{H}_{2} \mathrm{O}$

$-\quad 3.05$

Sillen and Martell (1964)

$\mathrm{Sb}_{2} \mathrm{O}_{3}$ (orthorhombic) $+2 \mathrm{H}^{+}$

$\neq 2 \mathrm{SbO}^{+}+\mathrm{H}_{2} \mathrm{O}$

$-2.32$

$\mathrm{Sb}_{2} \mathrm{O}_{4}+2 \mathrm{H}^{+}$

$\rightleftarrows 2 \mathrm{SbO}^{+}+0.5 \mathrm{O}_{2}+\mathrm{H}_{2} \mathrm{O}$

$-18.56$

Charlot (1958); Wagman

$\mathrm{Sb}_{4} \mathrm{O}_{6}+4 \mathrm{H}^{+}$

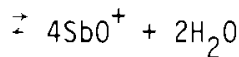

$-14.96$

et al. (1968)

$\mathrm{Sb}(\mathrm{OH})_{3}+\mathrm{H}^{+}$

$\therefore \mathrm{SbO}^{+}+2 \mathrm{H}_{2} \mathrm{O}$

$-5.93$

$\mathrm{Sb}_{2} \mathrm{O}_{5}+2 \mathrm{H}^{+}$

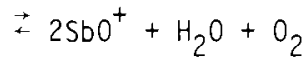

$-41.66$

$\mathrm{Sb}_{3} \mathrm{~S}_{3}+2 \mathrm{H}_{2} \mathrm{O}+6 \mathrm{O}_{2}$

$\rightarrow 2 \mathrm{SbO}^{+}+3 \mathrm{SO}_{4}^{2}+4 \mathrm{H}^{+}$

339.95

$\mathrm{SbCl}_{3}+\mathrm{H}_{2} \mathrm{O}$

$\stackrel{\mathrm{SbO}}{+} 3 \mathrm{Cl}^{-}+2 \mathrm{H}^{+}$

1.74

$\mathrm{SbF}_{3}+\mathrm{H}_{2} \mathrm{O}$

$\pm \mathrm{SbO} 0^{+}+3 \mathrm{~F}^{-}+2 \mathrm{H}^{+}$

$-10.44$

Garrels and Christ (1965)

\section{Oxidation-Reduction Reactions}

$\mathrm{Sb}(\mathrm{s})+\mathrm{H}_{2} \mathrm{O}$
$\mathrm{SbO}^{+}+\mathrm{H}_{2} \mathrm{O}$
$\mathrm{HSbO}_{2}^{\circ}$

$\stackrel{\mathrm{SbO}}{+}+2 \mathrm{H}^{+}+3 \overline{\mathrm{e}}$

$-10.53$

Wagman et al. (1968)

$+\mathrm{HSbO}_{2}^{\circ}+\mathrm{H}^{+}$

$-1.19$

$\rightarrow \mathrm{SbO}_{2}^{-}+\mathrm{H}^{+}$

$-11.79$

Hydrolys is and Other Reactions

$$
\begin{aligned}
& \mathrm{SbO}^{+}+2 \mathrm{H}_{2} \mathrm{O} \\
& \mathrm{SbO}^{+}+\mathrm{H}_{2} \mathrm{O} \\
& \mathrm{SbO}^{+}+\mathrm{H}_{2} \mathrm{O}+\mathrm{NH}_{4}^{+} \\
& \mathrm{SbO}^{+}+\mathrm{F}^{-}
\end{aligned}
$$

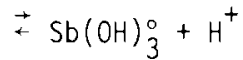

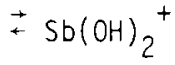$$
\mp \mathrm{NH}_{4} \mathrm{SbO}_{2}^{\circ}+2 \mathrm{H}^{+}
$$$$
0
$$$$
-11.79
$$

Wagman et al. (1968)

$\leftarrow \mathrm{SbOF}^{\circ}$

0

$-1.18$

0.20

$-12.98$

5.51
Wagman et a1. (1968)

Baes and Mesmer (1976);

Wagman et al. (1968)

Wagman et al. (1968) 


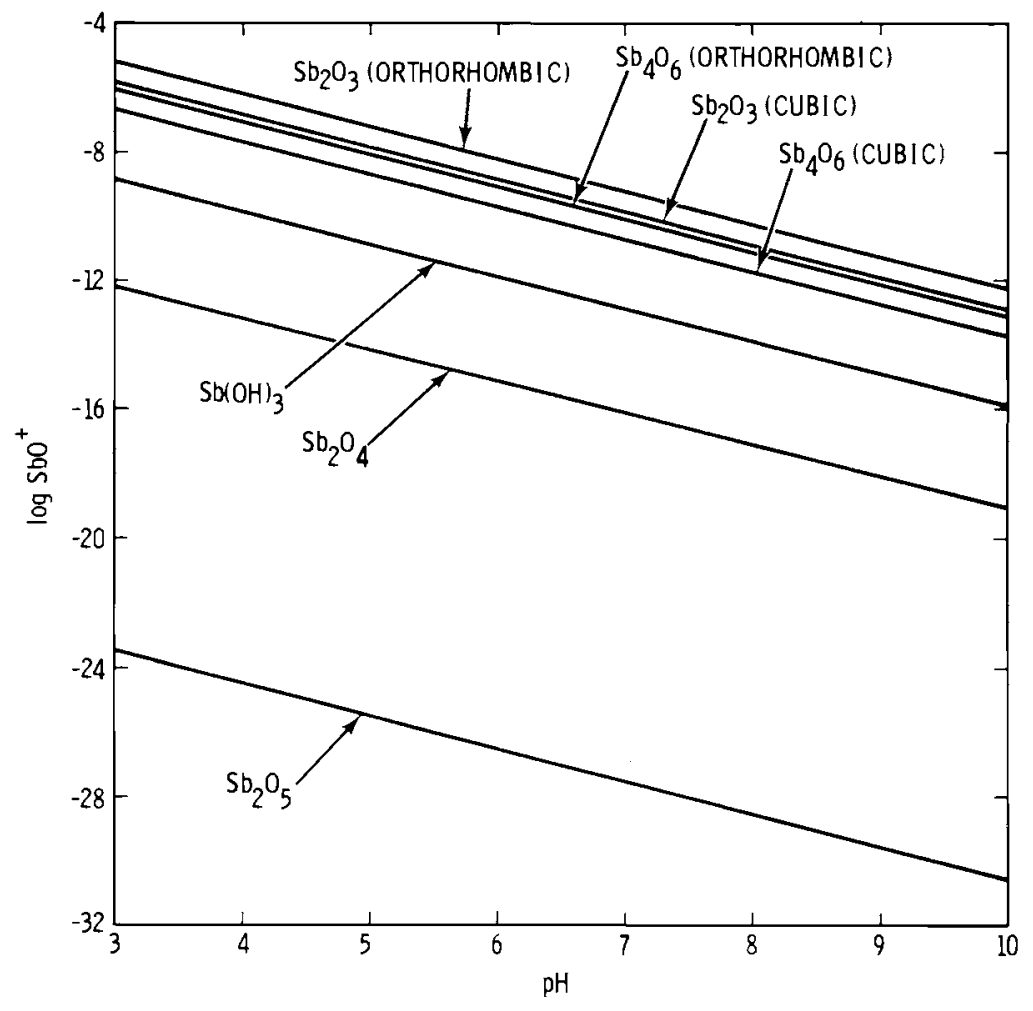

FIGURE 5. The Activity of Sbot in Equilibrium with Various Antimony Solids in an Oxidizing Soil Solution Environment $\left[\mathrm{pO}_{2}(\mathrm{~g})=0.68 \mathrm{~atm}\right]$ 


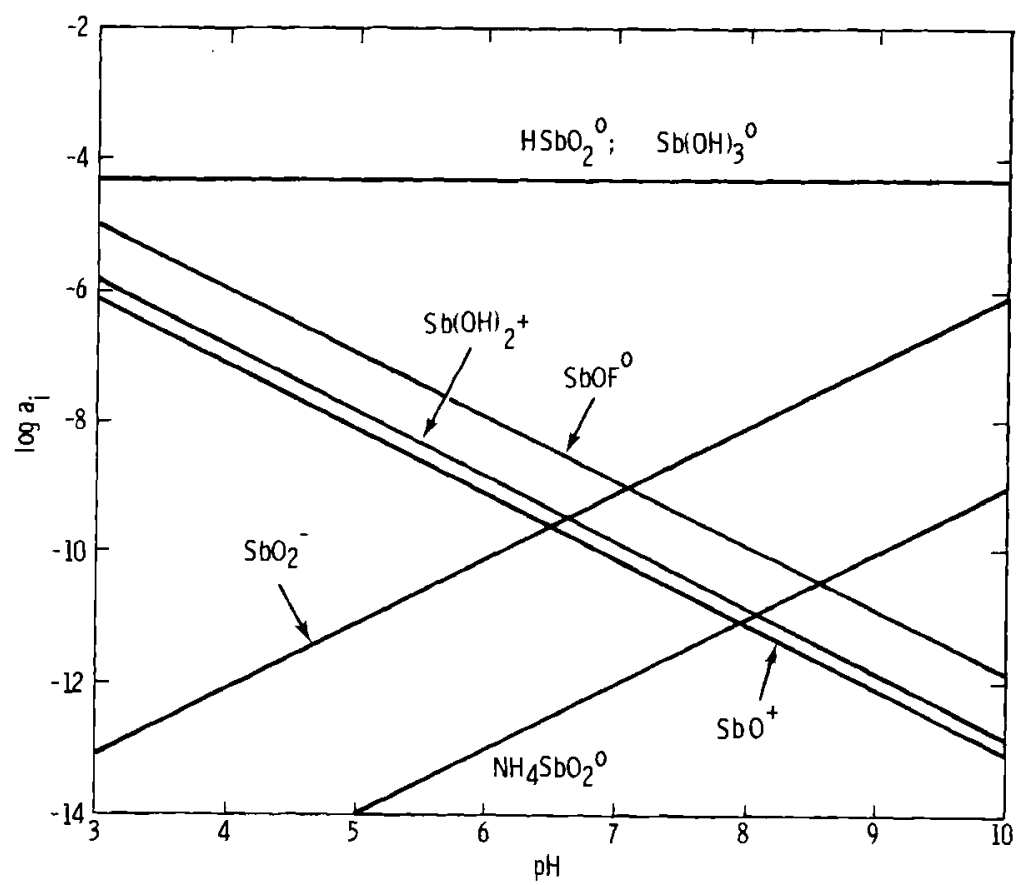

FIGURE 6. The Activity of Various Antimony Species in Equilibrium with $\mathrm{Sb}_{2} \mathrm{O}_{3}(\mathrm{~s})$ (cubic) with $\mathrm{pNH}_{4}^{+}=3.0$ and $\mathrm{pF}^{-}=4.5$. Oxidationreduction changes do not affect the concentration of species reports in this figure. 


\section{PREDICTED VS. OBSERVED BEHAVIOR OF ANTIMONY}

The principal aspect of antimony chemistry that governs its adsorption reactions with soils and rocks over the $\mathrm{pH}$ range 4 to 8 is the prevalence of neutral and complexed species (Figure 6). Low Kd values are found in high salt, high pH solutions as well (Serne, 1973), with relatively rapid migration through soils (Haney and Linderoth, 1959; Haney, 1967; Anonymous, 1973) and surface waters (Magno et al., 1970). There are indications that antimony can be precipitated or coprecipitated in solids even at low pH values (Jackson, 1976). In low redox conditions $\left(0_{2}<10^{-35}\right.$ atmospheres), antomony trihydroxide may precipitate and may be a stable compound that controls antimony concentrations (Figure 5). Many of the antimony species associated with organopollutants are water soluble (Saas and Grauby, 1973) and migrate readily with the water. Thermodynamic data on the antimony complexes formed with soil organic materials do not exist at present because the complexes are chemically poorly defined, and in many cases, unknown. 


\section{CERIUM}

The relative stability of various cerium solid phases is shown in Figure 7. The thermodynamic data of the compounds used in Figure 7 are reported in Table 5. Among the solids depicted in Figure 5, $\mathrm{CeO}_{2}$ is the only one that changes its position with a change in oxidation-reduction conditions. In an oxidizing environment $\left(\mathrm{pO}_{2}<23.68 \mathrm{~atm}\right)$, the solids in increasing order of stability are $\mathrm{Ce}_{2} \mathrm{O}_{3}, \mathrm{Ce}(\mathrm{OH})_{3}, \mathrm{CePO}_{4}$, and $\mathrm{CeO}_{2} \cdot \mathrm{Ce}_{2} \mathrm{~S}_{3}$ is too soluble to piot in Figure 3 in an oxidation-reduction environment where $\mathrm{SO}_{4}{ }^{2-}$ will be the most dominant sulfur species. In oxidation-reduction conditions corresponding to $\mathrm{pO}_{2}$ of $>23.68, \mathrm{CePO}_{4}$ would be the most stable solid phase.

The activity of various solution species of cerium in equilibrium with $\mathrm{CePO}_{4}$ (solid) and under such concentrations of $\mathrm{F}^{-}, \mathrm{Cl}^{-}, \mathrm{SO}_{4}^{2-}, \mathrm{NO}_{3}^{-}$, and $\mathrm{PO}_{4}^{3-}$ as commoniy found in the environment is shown in Figure 8. The thermodynamic data for the species presented in Figure 8 are reported in Table 5 . Since Figure 8 is based on solution complexes in equilibrium with $\mathrm{Ce}$ (III) as $\mathrm{CePO}_{4}$, Ce(IV) ions and complexes would decrease in activity with increase in reducing conditions. In the environmental $\mathrm{pH}$ range of interest the $\mathrm{Ce}$ (IV) ions and complexes do not contribute significantly to the total cerium concentration in solution.

Trivalent cerium species in increasing order of importance are $\mathrm{CeCl}^{2+}$, $\mathrm{CeNO}_{3}^{2+}, \mathrm{CeF}^{2+}, \mathrm{Ce}^{3+}$, and $\mathrm{CeSO}_{4}^{+}$. Thus, $\mathrm{CeSO}_{4}^{+}$would be the most dominant solution species in the environmental $\mathrm{pH}$ range of interest ( $\mathrm{pH} 4$ to 8 ). 


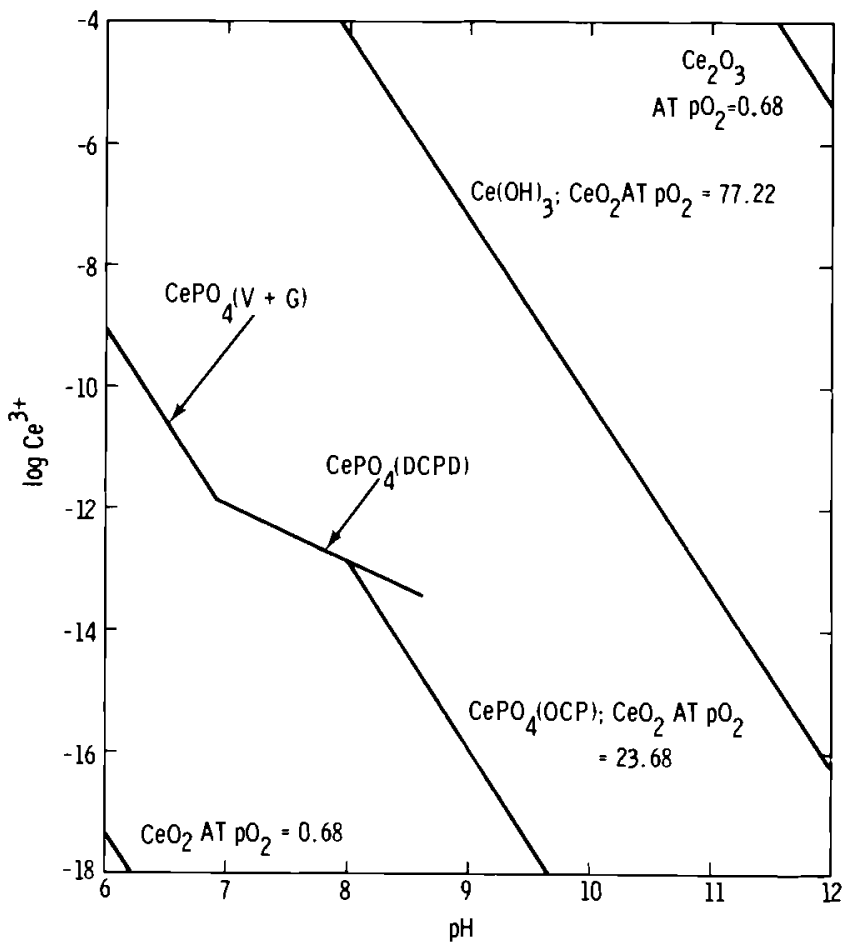

FIGURE 7. The Activity of $\mathrm{Ce}^{3+}$ in Equilibrium with Phosphate Levels from Variscite and Gibbsite (V and $G$ ), Dicalcium Phosphate Dihydrate (DCPD) and Octacalcium Phosphate (OCP) 


\section{TABLE 5. Selected Equilibrium Constants (K) at $25^{\circ} \mathrm{C}$ and One Atmosphere Pressure for Reactions Involving Cerium}

\begin{tabular}{|c|c|c|c|c|}
\hline \multicolumn{2}{|r|}{ Reaction } & $\underline{\operatorname{Medium}}(\mathrm{a})$ & \multirow[t]{2}{*}{ Log $K$} & \multirow[t]{2}{*}{ Reference } \\
\hline \multicolumn{3}{|c|}{ Solid Compounds } & & \\
\hline $\mathrm{Ce}_{2} \mathrm{O}_{3}+6 \mathrm{H}^{+}$ & $=2 \mathrm{Ce}^{3+}+3 \mathrm{H}_{2} \mathrm{O}$ & 0 & 61.20 & Schumm et a1. (1973) \\
\hline $\mathrm{Ce}(\mathrm{OH})_{3}+3 \mathrm{H}^{+}$ & 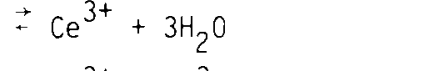 & 0 & 19.9 & Baes and Mesmer (1976) \\
\hline $\mathrm{CePO}_{4}$ & $\pm \mathrm{Ce}^{3+}+\mathrm{PO}_{4}^{3-}$ & di 1 & -21.3 & Sillen and Martell (1964) \\
\hline $\mathrm{CeO}_{2}+3 \mathrm{H}^{+}$ & $=\mathrm{Ce}^{3+}+1.5 \mathrm{H}_{2} \mathrm{O}+0.25 \mathrm{O}_{2}$ & 0 & 0.47 & Schumm et al. (1973) \\
\hline $\mathrm{Ce}_{2} \mathrm{~S}_{3}$ & $\therefore 2 \mathrm{Ce}^{3+}+3 \mathrm{~S}^{2-}$ & 0 & -10.22 & Sillen and Martell (1964) \\
\hline
\end{tabular}

Oxidation-Reduction Reactions

\begin{tabular}{|c|c|c|c|c|}
\hline $\mathrm{Ce}(\mathrm{s})$ & $\therefore \mathrm{Ce}^{3+}+3 \mathrm{e}^{-}$ & 0 & 117.7 & Schumm et a 1. (1973) \\
\hline $\mathrm{Ce}^{3+}$ & $\therefore \mathrm{Ce}^{4+}+\overline{\mathrm{e}}$ & 0 & 29.5 & " \\
\hline
\end{tabular}

Hydrolysis and Other Reactions

\begin{tabular}{|c|c|c|c|c|}
\hline $\mathrm{Ce}^{4+}+\mathrm{H}_{2} \mathrm{O}$ & $\because \mathrm{CeOH}^{3+}+\mathrm{H}^{+}$ & $3 \mathrm{CrO}_{4}^{-}$ & 1.1 & Baes and Mesmer (1976) \\
\hline $\mathrm{Ce}^{4+}+2 \mathrm{H}_{2} \mathrm{O}$ & $\because \mathrm{Ce}(\mathrm{OH})_{2}^{2+}+2 \mathrm{H}^{+}$ & $3 \mathrm{CrO}_{4}^{-}$ & 0.3 & 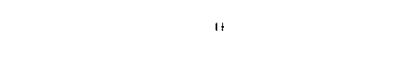 \\
\hline $2 \mathrm{Ce}^{4+}+2 \mathrm{H}_{2} \mathrm{O}$ & $\therefore \mathrm{Ce}_{2}(\mathrm{OH})_{2}^{6+}+2 \mathrm{H}^{+}$ & $3 \mathrm{ClO}_{4}^{-}$ & 3.6 & $"$ \\
\hline $2 \mathrm{Ce}^{4+}+3 \mathrm{H}_{2} \mathrm{O}$ & $\therefore \mathrm{Cl}_{2}(\mathrm{OH})_{3}^{5+}+3 \mathrm{H}^{+}$ & $3 \mathrm{ClO}_{4}^{-}$ & 4.1 & $"$ \\
\hline $2 \mathrm{Ce}^{4+}+4 \mathrm{H}_{2} \mathrm{O}$ & $\therefore \mathrm{Ce}_{2}(\mathrm{OH})_{4}^{4+}+4 \mathrm{H}^{+}$ & $3 \mathrm{ClO}_{4}^{-}$ & 3.5 & $"$ \\
\hline $2 \mathrm{Ce}^{3+}+2 \mathrm{H}_{2} \mathrm{O}$ & $\therefore \mathrm{Ce}_{2}(\mathrm{OH})_{2}^{4+}+2 \mathrm{H}^{+}$ & 0 & -15.5 & $"$ \\
\hline $3 \mathrm{Ce}^{3+}+5 \mathrm{H}_{2} \mathrm{O}$ & $\therefore \mathrm{Ce}_{3}(\mathrm{OH})_{5}^{4+}+5 \mathrm{H}^{+}$ & 0 & -33.5 & " \\
\hline $\mathrm{Ce}^{3+}+\mathrm{F}^{-}$ & $\therefore \mathrm{CeF}^{2+}$ & 0 & 4.0 & Sillen and Martell (1964) \\
\hline $\mathrm{Ce}^{3+}+\mathrm{Cl}^{-}$ & $\because \mathrm{CeCl}^{2+}$ & 0 & -0.78 & Schurim et al. (1973) \\
\hline $\mathrm{Ce}^{3+}+\mathrm{NO}_{3}^{-}$ & $\therefore \mathrm{CeNO}_{3}^{2+}$ & 0 & 1.09 & Sillen and Marteli (1964) \\
\hline $\mathrm{Ce}^{3+}+\mathrm{SO}_{4}^{2-}$ & $\therefore \mathrm{CeSO}_{4}^{+}$ & 0 & 3.47 & Schumm et a 1. (1973) \\
\hline
\end{tabular}

(a) The nature of the medium to which the equilibrium constants refer, for example, 0 - zero ionic strength, var - ionic medium varied, $2\left(\mathrm{HClO}_{4}\right)$ - ionic strength held constant at the value stated (2 moles/:1iter) by the addition of the chemical shown in parentheses, 1.0 $\mathrm{HClO}_{4}$ - constant concentration of the substance stated (1.0 moles/:1iter $\left.\mathrm{HClO}_{4}\right)$. 


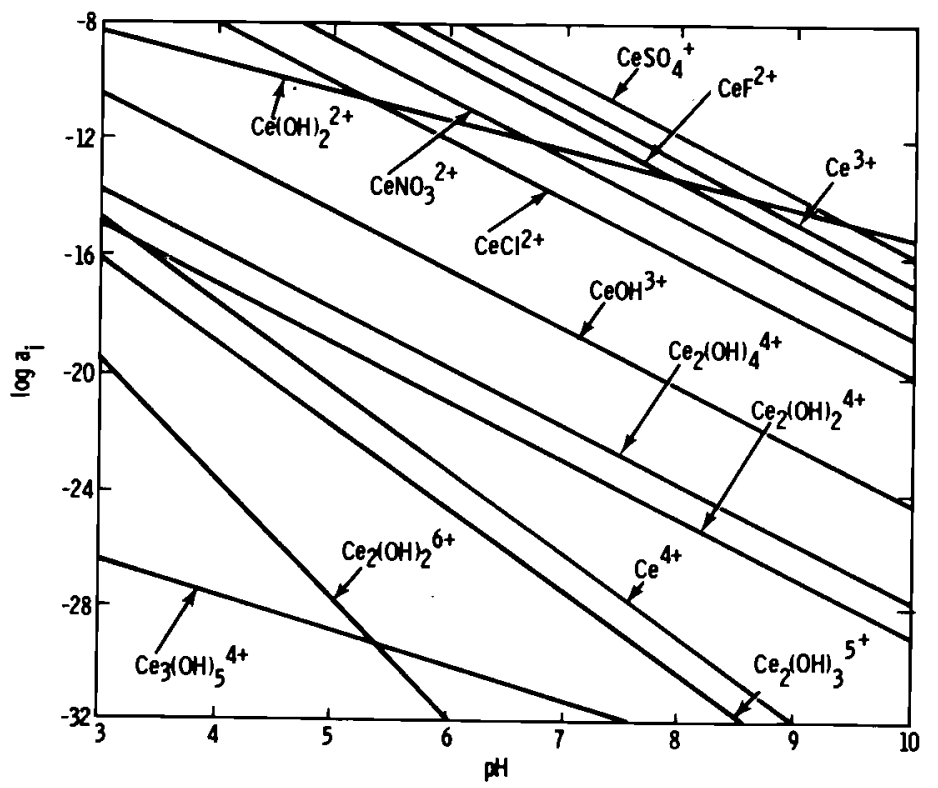

FIGURE 8. The Activity of Various Cerium Species in Equilibrium with $\mathrm{CePO}_{4}(\mathrm{~s})$ in an Oxidizing Soil Environment $[\mathrm{p} 02(\mathrm{~g})=$ $0.68 \mathrm{~atm}], \mathrm{pF}^{-}=4.5, \mathrm{pCl}^{-}=\mathrm{pSO}_{4}^{2-}=$ 2.5, $\mathrm{pNO}_{3}^{-}=3.0$ and $\mathrm{pH}_{2} \mathrm{PO}_{4}=5.0$ 
PREDICTED VS. OBSERVED BEHAVIOR OF CERIUM

No information is available on solid compounds of cerium that may be present in soils and sediments. It appears that $\mathrm{CePO}_{4}$ (Figures 7 and 8 ), especially in alkaline conditions, may form in soils and sediments and may control cerium concentrations.

In all terrestrial environments $\mathrm{Ce}$ (IV) and its complexes would have insignificant effects on cerium concentration (Figure 8 ). Thus, cerium would be expected to be present as Ce(III) (Figure 8 and Ahrens, 1952; Bensen, 1960). In the absence of strong complexing ligands, and especially in acidic environments, cerium would be expected to be present as $\mathrm{Ce}^{3+}$ (Figure 8; Bensen, 1960) and ion exchangeable. The increase in $\mathrm{pH}$ has been shown to increase the cerium adsorption (Rhodes, 1957; Bensen, 1960; Nishita, et a1., 1956; Kokotov, et a1., 1962; Kampbe11, 1964). As expected, the presence of complexing ligands such as DTPA increases cerium concentration in solution and reduces adsorption (Kampbe11, 1964). In slightly acidic (pH 6.5) to alkaline conditions, cerium is thought to be present as radiocolloid which has been shown to increase adsorption (Rhodes, 1957; Brown, et a1., 1969). Kampbe11 (1964) reported that kaolinite, montmorillonite, and illite have a strong affinity for cerium. Cerium adsorbed on suspended solids has been shown to migrate in field and laboratory studies (Magno, et a1., 1970; Eichholz, et al., 1967). However, this type of movement would be expected to be dependent upon the particle size of the suspended solids and the pore size distribution of soils and rocks. 


\section{CESIUM}

Thermodynamic data was collected for the following solid phases of cesium: $\mathrm{Cs}(\mathrm{OH}), \mathrm{Cs}_{2} \mathrm{O}, \mathrm{CsCl}, \mathrm{CsClO}_{4}, \mathrm{Cs}_{2} \mathrm{SO}_{4}, \mathrm{Cs}_{2} \mathrm{CO}_{3}, \mathrm{CsHCO}_{3}, \mathrm{CsNO}_{3}, \mathrm{CsF}$. All are highly soluble and, therefore, solid phase diagrams for cesium are not presented.

Baes and Mesmer (1976) report that cesium may be associated with $\mathrm{OH}^{-}$ ions in solution and that the extent of this association cannot be estimated accurately. Charlot (1957) reported that cesium rarely forms solution complexes. Therefore, cesium would be expected to appear in solutions predominantly as $\mathrm{Cs}^{+}$. Only $1.5 \%$ of the cesium from underground nuclear explosions was found (Izrael et al., 1969) to be colloidal, which may have been adsorbed on other colloids. The main soil and rock reactions with cesium is expected to be ion exchange. 


\section{PREDICTED VS. OBSERVED BEHAVIOR OF CESIUM}

Cesium mainly exists in solutions as $\mathrm{Cs}^{+}$. Therefore, the principal reaction mechanism of cesium adsorption on soils and rocks is expected to be cation exchange. In some instances cesium shows a direct Kd-cation exchange capacity relationship (Routson, 1973), and in other instances, no relation between $\mathrm{Kd}$ and exchange capacity (Jacobs, 1962). At trace cesium concentrations competing cation effects are minor (McHenry, 1954), while at $10 \%$ or more of the exchange capacity occupied by cesium, the Kd value beings to fall off (Prout, 1958). Potassium is better than sodium or calcium for desorbing cesium (Davis, 1961). There is a tendency for cesium to become "fixed" in 10^ mica-like minerals (Tamura and Jacobs, 1961; Jacobs, 1962; Tamura, 1963; Coleman et a1., 1963; Lomenick, 1967), which may be due to a slow desorption rate rather than fixation (Levi and Miekeley, 1967; Routson, 1973). The secondary silicate minerals such as zeolites and clay minerals generally show much higher cesium Kd values that the primary silicate minerals found in igneous rocks (Berak, 1963).

The migration rate of cesium in the groundwater is faster at lower $\mathrm{pH}$ values but slower through clays than through sands due to larger clay Kd values (Baetsle et a1., 1964). Much of the cesium that migrates in surface waters does so adsorbed on suspended solids (Eichholz et al., 1967; Magno et a1., 1970).

Occasionally cesium can migrate through the soil column adsorbed on suspended solids (Carlile and Hajek, 1967). Chelating agents and organic soil materials have little affect on cesium migration through soils (Nishita and Essington, 1967; Knol1, 1969; Salo and Saxen, 1974). 


\section{COBALT}

The thermodynamic data and their sources for various solid phases of Cobalt are reported in Table 6 and these data are plotted in Figure 9 . The stability of cobalt solid phases depends on the $\mathrm{pH}$ and the oxidation-reduction environment. For example, in acidic $(\mathrm{pH} 6)$ and oxidizing ( $\mathrm{pO}_{2} 0.68$ ) environments, the solids in increasing order of stability are: $\mathrm{Co}(\mathrm{OH})_{3}, \mathrm{CoO}, \mathrm{CoHPO}_{4}$, $\mathrm{Co}_{3}\left(\mathrm{PO}_{4}\right)_{2}, \mathrm{CoCO}_{3}, \mathrm{Co}_{3} \mathrm{O}_{4}$, and $\mathrm{COOOH}$ as shown in Figure 9. With the change in oxidation-reduction environment, all the minerals except $\mathrm{Co}(\mathrm{OH})_{3}, \mathrm{Co}_{3} \mathrm{O}_{4}$, and $\mathrm{COOOH}$ would stay in their relative positions. The latter minerals would decrease in stability. With the change in oxidation-reduction conditions from the extremely oxidizing condition to moderately well oxidized or reducing conditions $\left(\mathrm{pO}_{2}>20\right), \mathrm{CoCO}_{3}$ would be the most stable mineral. Under extremely reducing conditions such as $\mathrm{pO}_{2} 80, \mathrm{CoS}$ would be the most stable mineral. Cobalt sulfide $(\mathrm{COS})$ is the chief cobalt ore mineral. In general, the stability of all the cobalt minerals increases with an increase in $\mathrm{pH}$.

Cobalt exists as $\mathrm{Co}^{2+}$ and $\mathrm{Co}^{3+}$ and forms solution complexes with common soil anions $\left(\mathrm{OH}^{-}, \mathrm{Cl}^{-}, \mathrm{SO}_{4}^{2-}, \mathrm{NO}_{3}^{-}\right)$. The thermodynamic data for different solution species are reported in Table 6 . The relative concentration of these solution species in equilibrium with $\mathrm{CoCO}_{3}$ and in an oxidizing environment $\left(\mathrm{pO}_{2}\right.$ 0.68) is depicted in Figure 10. If a solid phase other than $\mathrm{CoCO}_{3}$ or a constant concentration of $\mathrm{Co}$ is chosen for the diagram, the lines will shift up and down, while the relative concentration of various solution species would stay the same.

It can be seen from the Figure 10 that cobaltinous ion $\left(\mathrm{Co}^{2+}\right)$ and its solution complexes are the most stable and dominant solution species in the oxidizing environment. The most dominant solution species up to a $\mathrm{pH}$ value of approximately 9.5 is $\mathrm{Co}^{2+}$. Beyond $\mathrm{pH} 9.5, \mathrm{Co}(\mathrm{OH})^{\circ}$ becomes dominant. The activity of $\mathrm{Co}^{2+}$ ion in solution decreases 100-fold with an increase of a $\mathrm{pH}$ unit, whereas the activity of $\mathrm{Co}(\mathrm{OH})^{\circ}{ }_{2}$ does not change with the $\mathrm{pH}$. These predictions are similar to Baes and Mesmer (1975). If $\mathrm{CoCO}_{3}$ was the solid phase that controlled the solubility, the total cobalt concentration in solution at $\mathrm{pH} 7$ would be approximately $10^{-7} \mathrm{M}$ and approximately $10^{-12} \mathrm{M}$ at $\mathrm{pH} 9.5$. 


\section{TABLE 6. Selected Equilibrium Constants (K) at $25^{\circ} \mathrm{C}$ and One Atmosphere Pressure for Reactions Involving Cobalt}

\begin{tabular}{|c|c|c|c|c|}
\hline \multicolumn{2}{|c|}{ Reaction } & Medium & $\log K$ & Reference \\
\hline \multicolumn{5}{|c|}{ Solid Compounds } \\
\hline $\mathrm{COO}+2 \mathrm{H}^{+}$ & $\rightarrow \mathrm{CO}^{2+}+\mathrm{H}_{2} \mathrm{O}$ & 0 & 13.59 & Chase et al. (1975) \\
\hline $\mathrm{Co}_{3} \mathrm{O}_{4}+6 \mathrm{H}^{+}$ & $\vec{\leftarrow} 3 \mathrm{Co}^{2+}+3 \mathrm{H}_{2} \mathrm{O}+0.5 \mathrm{O}_{2}$ & 0 & 13.99 & $"$ \\
\hline $\mathrm{COOOH}+2 \mathrm{H}^{+}$ & 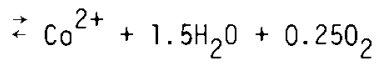 & 0 & 2.03 & Sillen and Martell (1964) \\
\hline $\mathrm{Co}(\mathrm{CH})_{3}+2 \mathrm{H}^{+}$ & 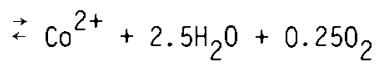 & 0 & 13.73 & $"$ \\
\hline $\mathrm{Co}(\mathrm{OH})_{2}($ pink $)+2 \mathrm{H}^{+}$ & $\neq \mathrm{Co}^{2+}+2 \mathrm{H}_{2} \mathrm{O}$ & 0 & 13.04 & Wagman et al. (1969) \\
\hline $\mathrm{Co}(\mathrm{OH})_{2}($ pink aged $)+2 \mathrm{H}^{+}$ & 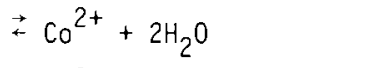 & 0 & 12.34 & $"$ \\
\hline $\mathrm{Co}(\mathrm{OH})_{2}($ blue $)+2 \mathrm{H}^{+}$ & $\rightleftarrows \mathrm{CO}^{2+}+2 \mathrm{H}_{2} \mathrm{O}$ & 0 & 13.77 & $"$ \\
\hline $\mathrm{CoHPO}_{4}$ & $\rightleftarrows \mathrm{CO}^{2+}+\mathrm{PO}_{4}^{3-}+\mathrm{H}^{+}$ & 0 & -18.70 & $"$ \\
\hline $\mathrm{Co}_{3}\left(P_{4}^{0}\right)_{2}$ & 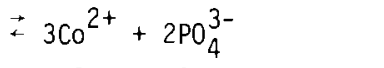 & 0 & -33.94 & $"$ \\
\hline $\mathrm{CoCO}_{3}$ & $=\mathrm{Co}^{2+}+\mathrm{CO}_{3}^{2-}$ & 0 & -12.84 & Sillen and Martell (1964) \\
\hline $\cos +2 \mathrm{O}_{2}$ & 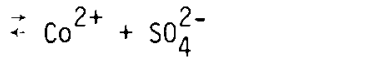 & 0 & -125.49 & Wagman et al. (1969) \\
\hline \multicolumn{5}{|c|}{ Oxidation-Reduction Reactions } \\
\hline $\operatorname{Co}(s)$ & 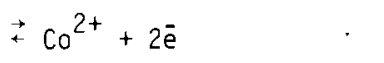 & 0 & 9.53 & Wagman et al. (1969) \\
\hline $\mathrm{CO}^{2+}$ & $\rightarrow \mathrm{Co}^{3+}+\overline{\mathrm{e}}$ & 0 & -32.99 & $"$ \\
\hline \multicolumn{5}{|c|}{ Hydrolysis and 0ther Reactions } \\
\hline $\mathrm{Co}^{2+}+\mathrm{H}_{2} \mathrm{O}$ & $\stackrel{\rightarrow}{ } \mathrm{COOH}^{+}+\mathrm{H}^{+}$ & 0 & -9.65 & Baes and Mesmer (1976) \\
\hline $\mathrm{Co}^{2+}+2 \mathrm{H}_{2} \mathrm{O}$ & 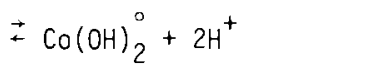 & 0 & -18.8 & $"$ \\
\hline $\mathrm{Co}^{2+}+3 \mathrm{H}_{2} \mathrm{O}$ & $\rightleftarrows \mathrm{CO}(\mathrm{OH})_{3}^{-}+3 \mathrm{H}^{+}$ & 0 & -31.5 & $"$ \\
\hline $\mathrm{CO}^{2+}+4 \mathrm{H}_{2} \mathrm{O}$ & $\rightleftarrows \mathrm{Co}(\mathrm{OH})_{4}^{2-}+4 \mathrm{H}^{+}$ & 0 & -46.5 & $"$ \\
\hline $\mathrm{Co}^{2+}+2 \mathrm{Cl}$ & $\stackrel{\mathrm{CoCl}_{2}^{\circ}}{\circ}$ & 0 & -0.03 & Wagman et al. (1969) \\
\hline $\mathrm{CO}^{2+}+\mathrm{SO}_{4}^{2-}$ & $\rightleftarrows \mathrm{CoSO}_{4}^{\circ}$ & 0 & +0.02 & $"$ \\
\hline $\mathrm{Co}^{2+}+2 \mathrm{NO}_{3}^{-}$ & $\stackrel{\mathrm{I} O}{ }\left(\mathrm{NO}_{3}\right)_{2}^{\circ}$ & 0 & -0.015 & $"$ \\
\hline $\mathrm{CO}^{2+}+\mathrm{P}_{2} \mathrm{O}_{7}^{4-}$ & $\stackrel{\rightarrow}{\mathrm{COP}_{2} 0_{7}^{2-}}$ & Variable & 3.02 & Sillen and Martell (1964) \\
\hline $\mathrm{Co}^{3+}+\mathrm{SO}_{4}^{2-}$ & $\rightarrow \cos _{4}^{+}$ & $2.7\left(\mathrm{NaClO}_{4}\right)$ & 1.34 & $"$ \\
\hline
\end{tabular}

(a) The nature of the medium to which the equilibrium constants refer, for example, 0 - zero ionic strength, var - ionic medium varied, $2\left(\mathrm{HClO}_{4}\right)$ - ionic strength held constant at the value stated (2 moles/liter) by the addition of the chemical shown in parentheses, 1.0 $\mathrm{HClO}_{4}$ - constant concentration of the substance stated (1.0 moles/2liter $\left.\mathrm{HClO} 4\right)$. 


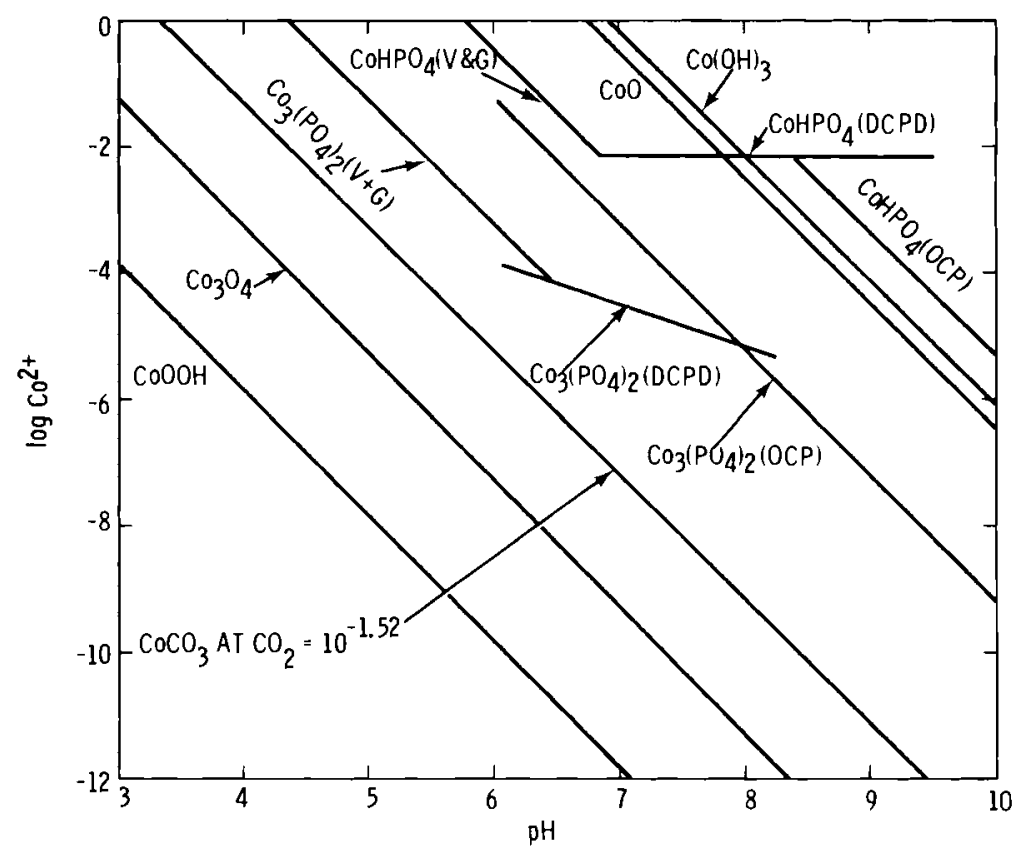

FIGURE 9. The Relative Stability of Cobalt Solids in an Oxidizing Environment $\left[\mathrm{pO}_{2}(\mathrm{~g})=0.68 \mathrm{~atm}\right]$, $\mathrm{pCa} 2+=2.5$ and Phosphate Levels in Equilibrium with Variscite and Gibbsite ( $V$ and $G$ ), Dicalcium and Phosphate Dihydrate (DCPD) and Octacalcium Phosphate (OCP) 


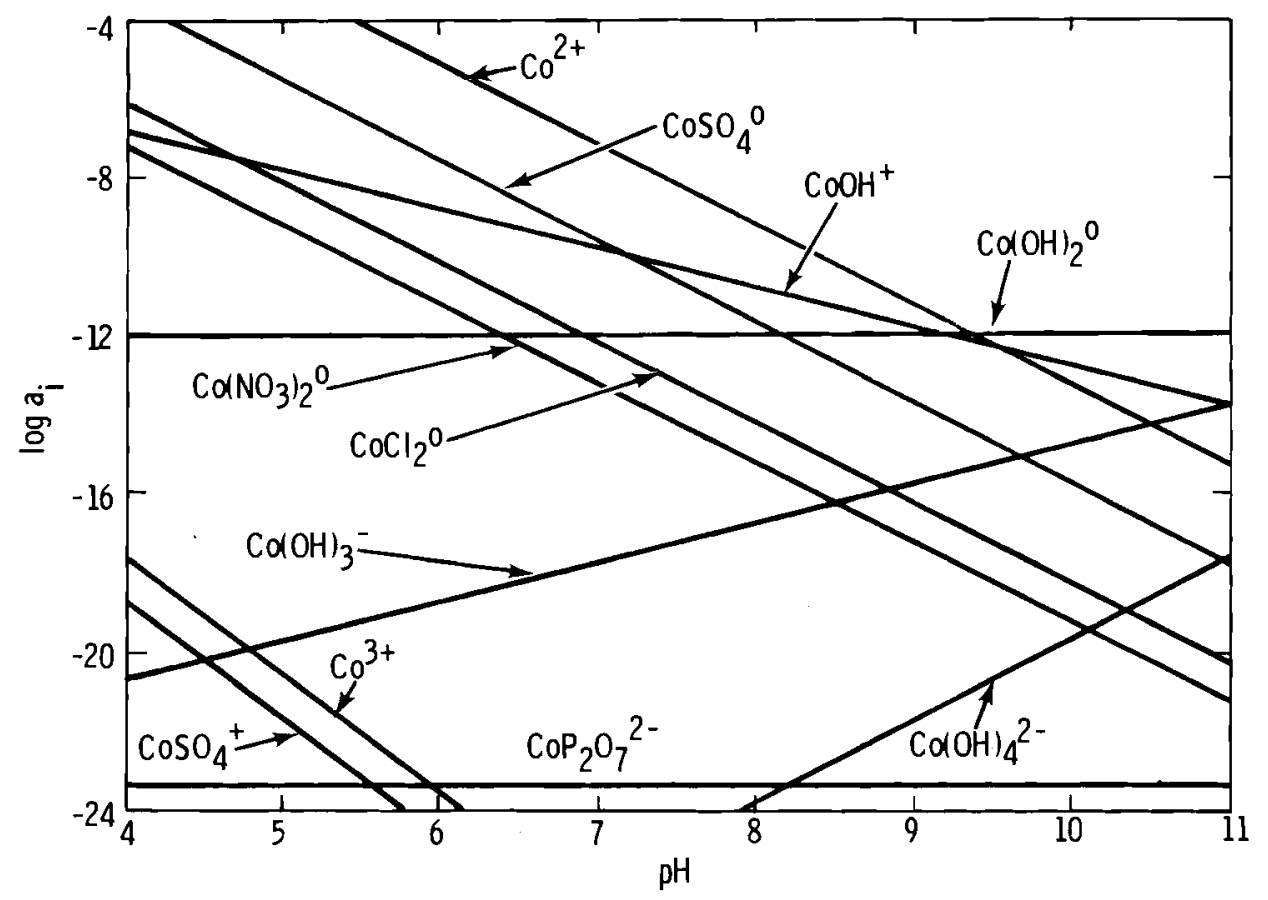

FIGURE 10. The Activity of Various Cobalt Ions in Equilibrium with $\mathrm{COCO}_{3}(\mathrm{~s})$ in an Oxidizing Soil Environment $[\mathrm{p0} 2(\mathrm{~g})=0.68 \mathrm{~atm}], \mathrm{pCO}_{2}(\mathrm{~g})=1.52 \mathrm{~atm}, \mathrm{pCl}^{-}=$ $\mathrm{pSO}_{4} 2^{-}=2.5, \mathrm{pNO}_{3}^{-}=3.0$ and $\mathrm{pH}_{2} \mathrm{PO}_{4}^{-}=5.0$ 
PREDICTED VS. OBSERVED BEHAVIOR OF COBALT

Discrete cobalt minerals have not been identified in soils. High concentrations of cobalt are required to precipitate cobalt minerals presented in Figure 9 under acidic pH values. It is not likely that any of the minerals would exist in the acidic soil environment. However, in highly alkaline conditions, $\mathrm{CoCO}_{3}$ would maintain fairly low concentrations of $\mathrm{Co}$ in solution and thus could exist in the soil environment.

The thermodynamic data indicates that through a wide $\mathrm{pH}$ range $(\mathrm{pH}<9.5$ ), cobalt would predominantly exist as $\mathrm{Co}^{2+}$ and with the increase in $\mathrm{pH}$ it hydrolyzes to $\mathrm{COOH}^{+}$and $\mathrm{Co}\left(\mathrm{OH}^{\circ}\right)_{2}$ (Figure 10). These predictions are consistent with the laboratory results as are outlined below. Among the various soil components, $\mathrm{Fe}_{2} \mathrm{O}_{3}$ (Gonzales and Gomez, 1961) and illite (Friend, 1963; Sorathesn et al., 1960) have been shown to have a strong affinity for cobalt. The adsorption of cobalt by soil minerals have been attributed to mainly an ion exchange phenomenon (Hawkins, 1964; Basu and Mukherjee, 1965). With the increase in $\mathrm{pH}$ (especially 6 to 9) the adsorption of cobalt increases (James and Healy, 1972; Tewari, Campbell and Lee, 1972). This increases in adsorption with $\mathrm{pH}$ has generally been explained as due to the formation of cobalt colloids (Sorathesn et al., 1960) and hydrolysis of $\mathrm{Co}^{2+}$ (Tewari et al., 1972). The presence of various complexing ions such as EDTA, cyanide, and fulvic acids have been shown to reduce the adsorption by soil minerals (Wilding and Rhodes, 1963; Rhodes and Nelson, 1957; Dunigan and Francis, 1972).

Cobalt is apparently relatively easily complexed by natural organics (Duguid, 1976; Means et a1., 1976) and by synthetical1y-produced organics (Haney, 1967; Saas and Grauby, 1973), and as such is able to migrate with relative ease through the soil column with which it would normally react by adsorption. 


\section{CURIUM}

Curium forms hydride, hydroxide, halides, oxides, and organometallic compounds (Keller, 1971). Except for $\mathrm{CmF}_{3}$, a search for thermodynamic data for these compounds was unsuccessful. Therefore, predictions regarding the stability of formation of various compounds of curium in soils cannot be made at this time.

Curium is found in two oxidation states [ $\mathrm{Cm}$ (III) and $\mathrm{Cm}(\mathrm{IV})]$ in aqueous solution (Keller, 1971). Curium (IV) is not stable in solutions because of self-radiation and rapid changes to $\mathrm{Cm}$ (III). Only trivalent curium is stable in aqueous solutions. Keller (1971) reports that the behavior of $\mathrm{Cm}^{3+}$ in solution is similar to lanthanide elements. Most of the lanthanides form trivalent hydroxides in natural waters with solubility products of $<10^{-19}$ (Vickery, 1953). Thomas and Jacobs (1969) found that the activity of curium in $0.1 \mathrm{M} \mathrm{NaCl}$ solutions which contained approximately $10^{-11} \mathrm{~m} / \ell$ of curium decreased at $\mathrm{pH}$ values above 3 . They attributed this decrease in activity in pure solutions to either precipitation or adsorption on walls. If this is assumed to be due to precipitation, the solubility product of curium hydroxide would be at least as low as the lanthanides, and probably much lower.

Since thermodynamic data for the curium compounds is not available, it was decided to plot the solution species in equilibrium with $\mathrm{Cm}(\mathrm{OH})_{3}$ with an assumed $\log \mathrm{K}^{\circ}$ of $\mathrm{Z}$ for the dissolution of $\mathrm{Cm}(\mathrm{OH})_{3}\left[\mathrm{Cm}(\mathrm{OH})_{3}+3 \mathrm{H}^{+}+\mathrm{Cm}^{3+}\right.$ $\left.+3 \mathrm{H}_{2} \mathrm{O}\right]$ in order to show the relative activity of various solution species of curium with the changes in $\mathrm{pH}$. Keller (1971) reviewed the curium data and stated that little work has been performed on the complex chemistry of curium and since a wide variation occurs in stability constants determined by various authors, these values should be regarded as relative rather than absolute. The thermodynamic data used to develop Figure 11 are reported in Table 7. 
It can be seen from Figure 11 that curium forms various solution complexes with $\mathrm{OH}^{-}, \mathrm{F}^{-}, \mathrm{Cl}^{-}, \mathrm{NO}_{3}^{-}, \mathrm{SO}_{4}^{2-}$, and $\mathrm{PO}_{4}^{3-}$. The activity of all the complexes decreases with the increase in $\mathrm{pH}$. The solution complexes of $\mathrm{PO}_{4}^{3-}, \mathrm{Cl}^{-}, \mathrm{NO}_{3}^{-}$, do not contribute significantly to the total curium concentration in solutions. The most dominant solution species in $\mathrm{pH}$ ranges of $<3.3,3.3-5.7,5.7$ and up are $\mathrm{Cm}^{3+}, \mathrm{Cm}(\mathrm{OH})^{2+}$, and $\mathrm{Cm}(\mathrm{OH})_{2}^{+}$, respectively. 


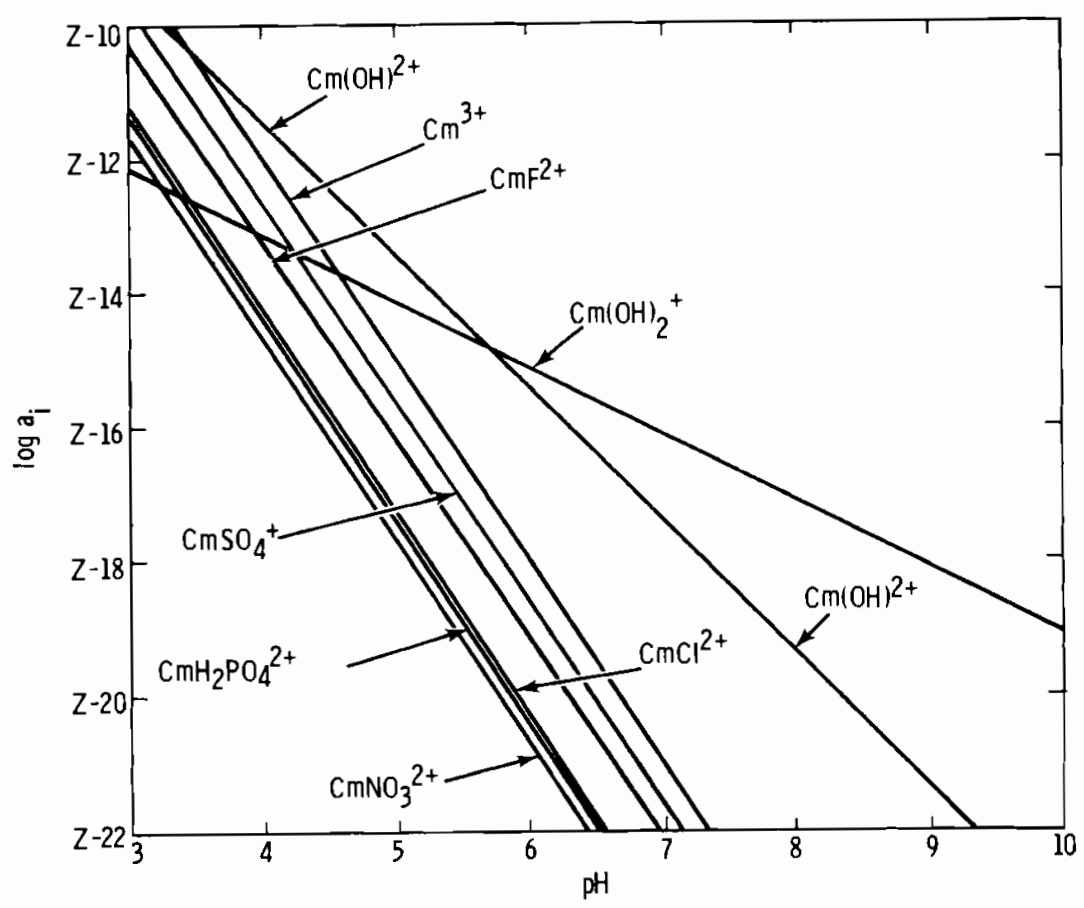

FIGURE 11. The Activity of Various Curium Ion Species in Equilibrium with $\mathrm{Cm}(\mathrm{OH})_{3}(\mathrm{~s})$ with $\mathrm{pF}^{-}=$ $4.5, \mathrm{pCl}^{-}=\mathrm{pSO}_{4}{ }^{2-}=2.5, \mathrm{pNO}_{3}^{-}=3.0$ and $\mathrm{pH}_{2} \mathrm{PO}_{4}^{-}=5.0$ 
TABLE 7. Selected Equilibrium Constants (K) at $25^{\circ} \mathrm{C}$ and One Atmosphere Pressure for Reactions Involving Curium

Oxidation-Reduction Reactions

\begin{tabular}{|c|c|c|c|c|c|}
\hline $\mathrm{Cm}(\mathrm{s})$ & $\overrightarrow{+} \mathrm{Cm}^{3+}+3 \overline{\mathrm{e}}$ & 0 & 117.15 & Keller & (1971) \\
\hline $\mathrm{Cm}^{3+}$ & $\rightleftarrows \mathrm{Cm}^{4+}+\overline{\mathrm{e}}$ & 0 & -52.40 & & $"$ \\
\hline $\mathrm{Cm}^{3+}+2 \mathrm{H}_{2} \mathrm{O}$ & $\vec{*} \mathrm{CnO}_{2}^{+}+4 \mathrm{H}^{+}+2 \overline{\mathrm{e}}$ & 0 & -98.05 & Nugent & $(1975)$ \\
\hline $\mathrm{Cm}^{3+}+2 \mathrm{H}_{2} \mathrm{O}$ & $\vec{\leftarrow} \mathrm{CmO}_{2}^{2+}+4 \mathrm{H}^{+}+3 \overline{\mathrm{e}}$ & 0 & -131.86 & & $" 1$ \\
\hline
\end{tabular}

Hydrolys is and Other Reactions

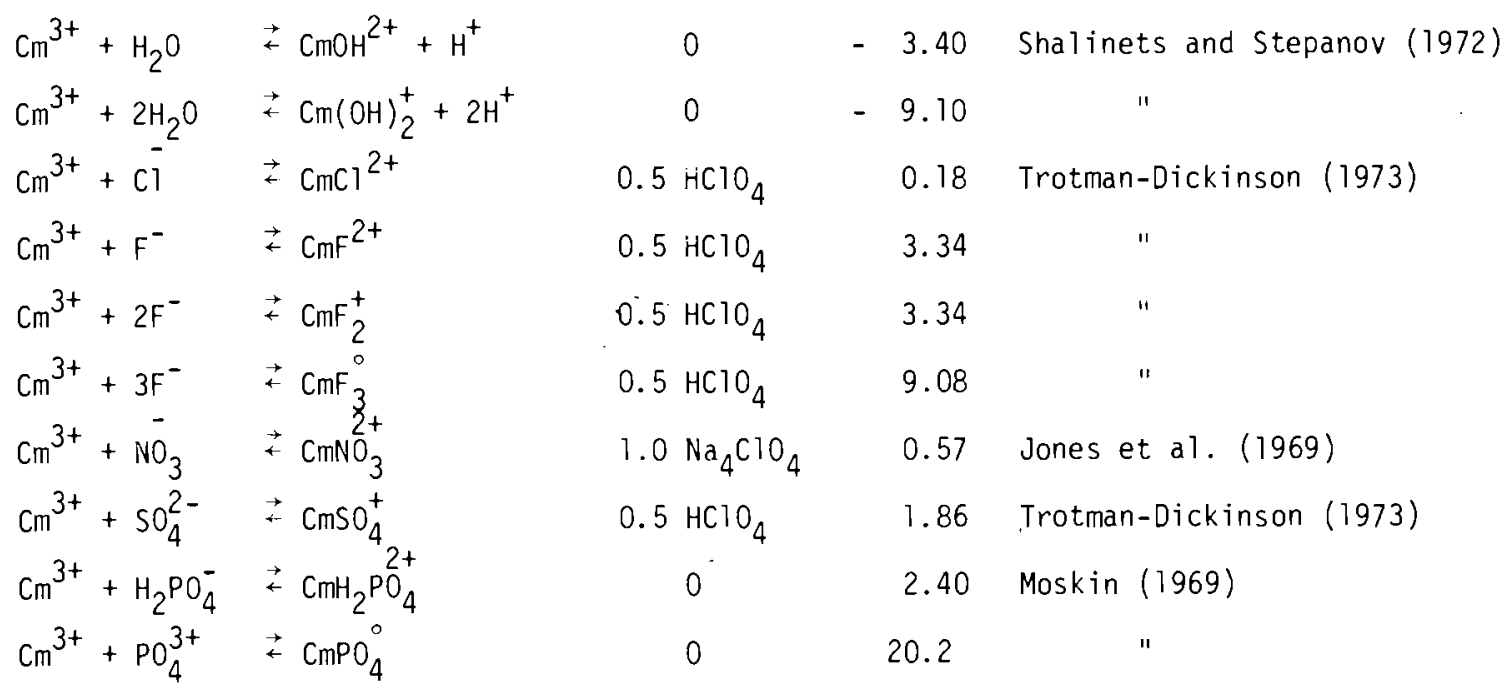

(a) The nature of the medium to which the equilibrium constants refer, for example, 0 - zero ionic strength, var - ionic medium varied, $2\left(\mathrm{HClO}_{4}\right)$ - ionic strength held constant at the value stated (2 moles/xiter) by the addition of the chemical shown in parentheses, 1.0 $\mathrm{HClO}_{4}$ - constant concentration of the substance stated ( 1.0 moles/2liter $\left.\mathrm{HClO}_{4}\right)$. 


\section{PREDICTED VS. OBSERVED BEHAVIOR OF CURIUM}

No information is available on possible curium compounds in soils and sediments. It appears that curium precipitation as $\mathrm{Cm}(\mathrm{OH})_{3}$ in alkaline solutions may control curium concentrations in those solutions. Theoretical calculations (Figure 11) indicate that $\mathrm{Cm}^{3+}$ hydrolyzes even in acidic solutions (pH 3.3 and above). Very little reliable information is available on interactions of curium with soils and sediments, and none on curium interactions with rocks. What little data are available indicate that curium adsorption is not a function of ion exchange capacity of the soil (Thomas and Jacobs, 1969; Jacobs et a1., 1966), and that precipitation and/or formation of radiocolloids may predominately influence curium adsorption reactions (Thomas and Jacobs, 1969; Sheppard et a1., 1976). 


\section{EUROPIUM}

Europium forms oxides, hydroxides, and salts with chlorides and sulfates [EuO, $\mathrm{Eu}_{2} \mathrm{O}_{3}, \mathrm{Eu}_{3} \mathrm{O}_{4}, \mathrm{Eu}(\mathrm{OH})_{3}, \mathrm{EuCl}_{3} \cdot 6 \mathrm{H}_{2} \mathrm{O}$, and $\left.\mathrm{Eu}_{2}\left(\mathrm{SO}_{4}\right)_{3} \cdot 8 \mathrm{H}_{2} \mathrm{O}\right]$. Thermodynamic data (Table 6) for these solid phases were used to plot the stability of the minerals (Figure 12). It can be seen that, except for the hydroxides $\left[\mathrm{Eu}(\mathrm{OH})_{3}\right]$, a11 the other minerals considered are too soluble in environmental $\mathrm{pH}$ ranges of interest ( $\mathrm{pH} \mathrm{4-10).} \mathrm{In} \mathrm{Figure} \mathrm{12,} \mathrm{Eu}(\mathrm{OH})_{3}, \mathrm{Eu}_{2} \mathrm{O}_{3}, \mathrm{Eu}_{2}\left(\mathrm{SO}_{4}\right)_{3} \cdot 8 \mathrm{H}_{2} \mathrm{O}$ are the only solids shown. The other solids were too soluble and fall beyond the graph boundaries. Of all the solids considered in Figure $12, \mathrm{Eu}(\mathrm{OH})_{3}$ is the most stable in alkaline environments.

Europium can exist as $\mathrm{Eu}^{2+}$ and $\mathrm{Eu}^{3+}$. However, $\mathrm{Eu}^{3+}$ is the only state which is stable in water (Baes and Mesmer, 1976). The thermodynamic data for various solution species are reported in Table 8 . The activity of various solution species of europium in equilibrium with $\mathrm{Eu}(\mathrm{OH})_{3}$ and at assumed concentrations of various anions commonly found in soils is given in Figure 13.

In a general way the solution complexes of europium in decreasing order of importance can be arranged as follows: $\mathrm{Eu}_{2} \mathrm{P}_{2} \mathrm{O}_{7}^{2+}, \mathrm{EuSO}_{4}^{+}, \mathrm{Eu}\left(\mathrm{SO}_{4}\right)_{2}^{+}$, EuF ${ }^{2+}$, $\mathrm{EuCl}^{2+}$, and $\mathrm{EuNO}_{3}^{2+}$. Under the conditions assumed in Figure 13, the predominant solution species in $\mathrm{pH}$ ranges of $\langle 4.5,4.5-7.75,7.5-8.85$, and $>8.85$ will be $\mathrm{EuSO}_{4}^{+}, \mathrm{Eu}_{2} \mathrm{P}_{2} \mathrm{O}_{7}^{2+}$, $\mathrm{EuSO}_{4}^{+}$, and $\mathrm{EuOH}^{2+}$, respectively. Thus, significant quantities of uncomplexed europium $\left(\mathrm{Eu}^{3+}\right)$ can only be expected in soils with very low levels of sulfate and phosphate. The solution complexes of europium with fluoride, chloride, and nitrate do not contribute significantly to total europium concentration in solution and hence can be ignored.

Serne and Rai (1976, unpublished data, Battelle Northwest, Richland, Washington 99352) studied the adsorption-precipitation behavior of europium in soils and pure solutions. The $\mathrm{pH}$ of the various europium solutions $\left(0.15 \mathrm{M} \mathrm{CaCl}_{2}\right.$ plus trace to $\left.50 \mathrm{mg} \mathrm{Eu} / 1\right)$ was increased in $0.05 \mathrm{pH}$ increments until precipitation was observed by the Tynda 11 Beam method. At the point of $\mathrm{Eu}(\mathrm{OH})_{3}$ precipitation, the europium activity and $\mathrm{pH}$ was determined. The results are plotted in Figure 14 along with the theoretical $\mathrm{Eu}(\mathrm{OH})_{3}$ solubility line. The results indicate that: 
1) the kinetics of precipitation of $\mathrm{Eu}(\mathrm{OH})_{3}$ is rapid

2) the laboratory results agree well with the theoretical $\mathrm{Eu}(\mathrm{OH})_{3}$ solubility

3) $\mathrm{Eu}^{3+}$ does not appear to hydrolyze appreciably and does not appear to form strong complexes with chloride, because total europium activity in equilibrium with $\mathrm{Eu}(\mathrm{OH})_{3}$ is similar to the calculated $\mathrm{Eu}^{3+}$ activity

4) for meaningful $\mathrm{Kd}$ values, the theoretical solubility of $\mathrm{Eu}(\mathrm{OH})_{3}$ should not be exceeded

Europium adsorption experiments where $\mathrm{Eu}(\mathrm{OH})_{3}$ did not precipitate were conducted (Serne and Rai, 1976), as shown in Table 9. The results show that the europium Kd increases with an increase in $\mathrm{pH}$ and decreases with increasing europium concentration, below the point of $\mathrm{Eu}(\mathrm{OH})_{3}$ precipitation. These reactions suggest that ion exchange is an active mechanism below the point of $\mathrm{Eu}(\mathrm{OH})_{3}$ precipitation. 


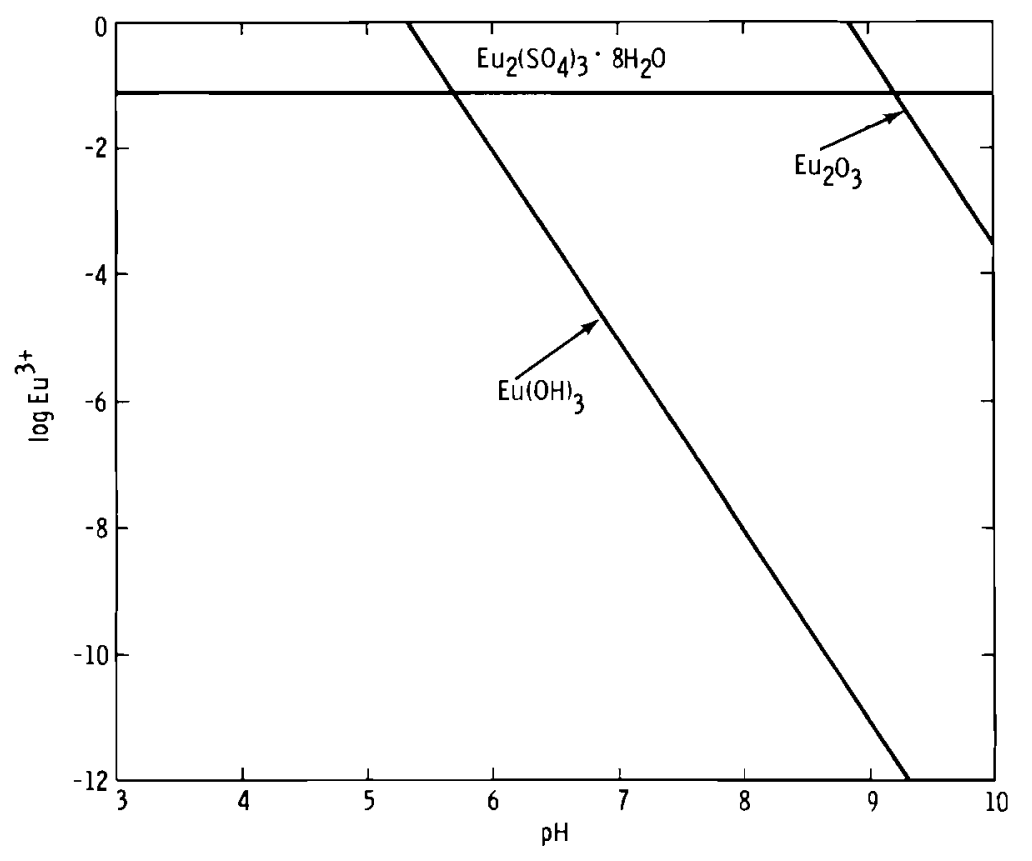

FIGURE 12. The Relative Stability of Various Europium Solids at $\mathrm{pSO}_{4}^{2-}=2.5$ 
TABLE 8. Selected Equilibrium Constants (K) at $25^{\circ} \mathrm{C}$ and One Atmosphere Pressure for Reactions Involving Europium

Reaction

$\underline{\operatorname{Medium}}(\mathrm{a}) \quad \underline{\log K}$

Reference

\section{Solid Compounds}

\begin{tabular}{|c|c|c|c|c|}
\hline $\mathrm{Eu}(\mathrm{OH})_{3}+3 \mathrm{H}^{+}$ & 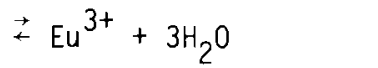 & 0 & 15.92 & Schumm et al. (1973) \\
\hline $\mathrm{Eu}_{2}\left(\mathrm{SO}_{4}\right)_{3} 8 \mathrm{H}_{2} \mathrm{O}$ & 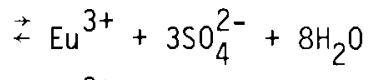 & 0 & -9.80 & Latimer (195i) \\
\hline EuO & $\stackrel{\mathrm{Eu}^{3+}+0.502}{ }+3 \overline{\mathrm{e}}$ & 0 & 3.01 & Schumm et a1. (1973) \\
\hline $\mathrm{Eu}_{2} \mathrm{O}_{3}+6 \mathrm{H}^{+}$ & $\stackrel{2}{ } 2 \mathrm{Eu}^{3+}+3 \mathrm{H}_{2} \mathrm{O}$ & 0 & 53.02 & $"$ \\
\hline $\mathrm{Eu}_{3} \mathrm{O}_{4}+8 \mathrm{H}^{+}$ & $\stackrel{\rightleftarrows}{\leftarrow} \mathrm{Eu}^{3+}+4 \mathrm{H}_{2} \mathrm{O}+\overline{\mathrm{e}}$ & 0 & 92.42 & $"$ \\
\hline
\end{tabular}

Oxidation-Reduction Reactions

$\begin{array}{lllll}\mathrm{Eu}(\mathrm{s}) & \stackrel{\mathrm{Eu}}{2+}+2 \overline{\mathrm{e}} & 0 & 94.65 & \text { Schumm et a1. (1973) } \\ \mathrm{Eu}^{2+} & \rightarrow \mathrm{Eu}^{3+}+\overline{\mathrm{e}} & 0 & 5.94\end{array}$

Hydrolys is and 0ther Reactions

\begin{tabular}{|c|c|c|c|c|}
\hline $\mathrm{Eu}^{3+}+\mathrm{H}_{2} \mathrm{O}$ & $\stackrel{\rightleftarrows}{\leftarrow} \mathrm{EuOH}^{2+}+\mathrm{H}^{+}$ & 0 & -7.8 & Baes and Mesmer (1976) \\
\hline $\mathrm{Eu}^{3+}+\mathrm{Cl}^{-}$ & $\rightarrow \mathrm{EuCl}^{2+}$ & 0 & 0.90 & Schumm et a1. (1973) \\
\hline $\mathrm{Eu}^{3+}+2 \mathrm{Cl}^{-}$ & $\stackrel{\mathrm{EuCl}_{2}^{+}}{+}$ & 0 & 0.19 & " \\
\hline $\mathrm{Eu}{ }^{3+}+\mathrm{F}^{-}$ & $\rightarrow \mathrm{EuF}^{2+}$ & $1 \mathrm{M}\left(\mathrm{NaClO}_{4}\right)$ & 3.19 & Walker and Choppin (1971) \\
\hline $\mathrm{Eu}^{3+}+\mathrm{NO}_{3}^{-}$ & $\stackrel{\mathrm{EuNO}_{3}^{2+}}{2+}$ & 0 & 0.31 & Schumm et al. (1973) \\
\hline $\mathrm{Eu}^{3+}+\mathrm{SO}_{4}^{2-}$ & $\rightarrow \mathrm{EuSO}_{4}^{+}$ & 0 & 3.55 & $"$ \\
\hline $\mathrm{Eu}^{3+}+2 \mathrm{SO}_{4}^{2-}$ & $\stackrel{\mathrm{Eu}}{ }\left(\mathrm{SO}_{4}\right)_{2}^{-}$ & 0 & 5.32 & " \\
\hline $2 E u^{3+}+2 \mathrm{PO}_{4}^{3-}$ & 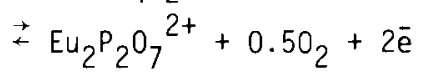 & 0 & -0.51 & $"$ \\
\hline
\end{tabular}

(a) The nature of the medium to which the equilibrium constants refer, for example, 0 - zero ionic strength, var - ionic medium varied, $2\left(\mathrm{HClO}_{4}\right)$ - ionic strength held constant at the value stated (2 moles/liter) by the addition of the chemical shown in parentheses, 1.0 $\mathrm{HClO}_{4}$ - constant concentration of the substance stated $\left(1.0\right.$ moles/liter $\left.\mathrm{HC}_{10}\right)$. 


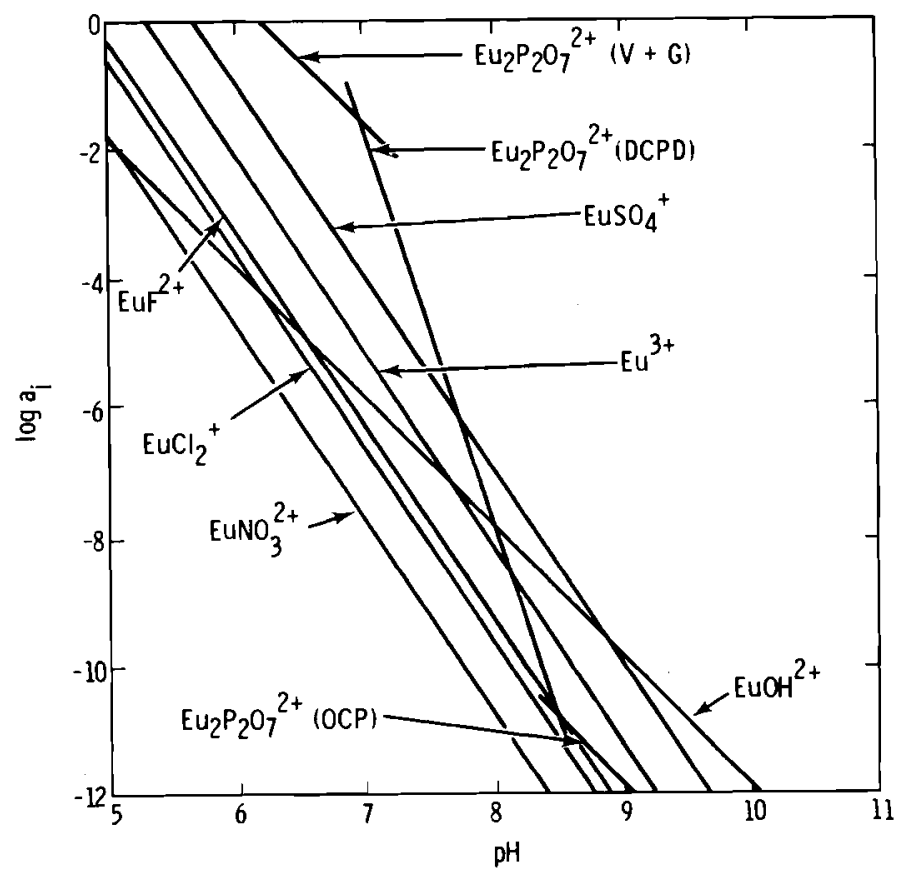

FIGURE 13. The Activity of Various Europium Species in Equilibrium with $\mathrm{Eu}(\mathrm{OH})_{3}(\mathrm{~s})$. Other conditions include $\mathrm{pSO} \mathrm{2}^{-}=\mathrm{pC}^{-}=2.5$, $\mathrm{pNO}_{\overline{3}}=3.0, \mathrm{pF}^{-}=4.5$ and phosphate levels in equilibrium with variscite and gibbsite ( $V$ and $G$ ), dicalcium phosphate dihydrate (DCPD), and Octacalcium phosphate (OCP) 


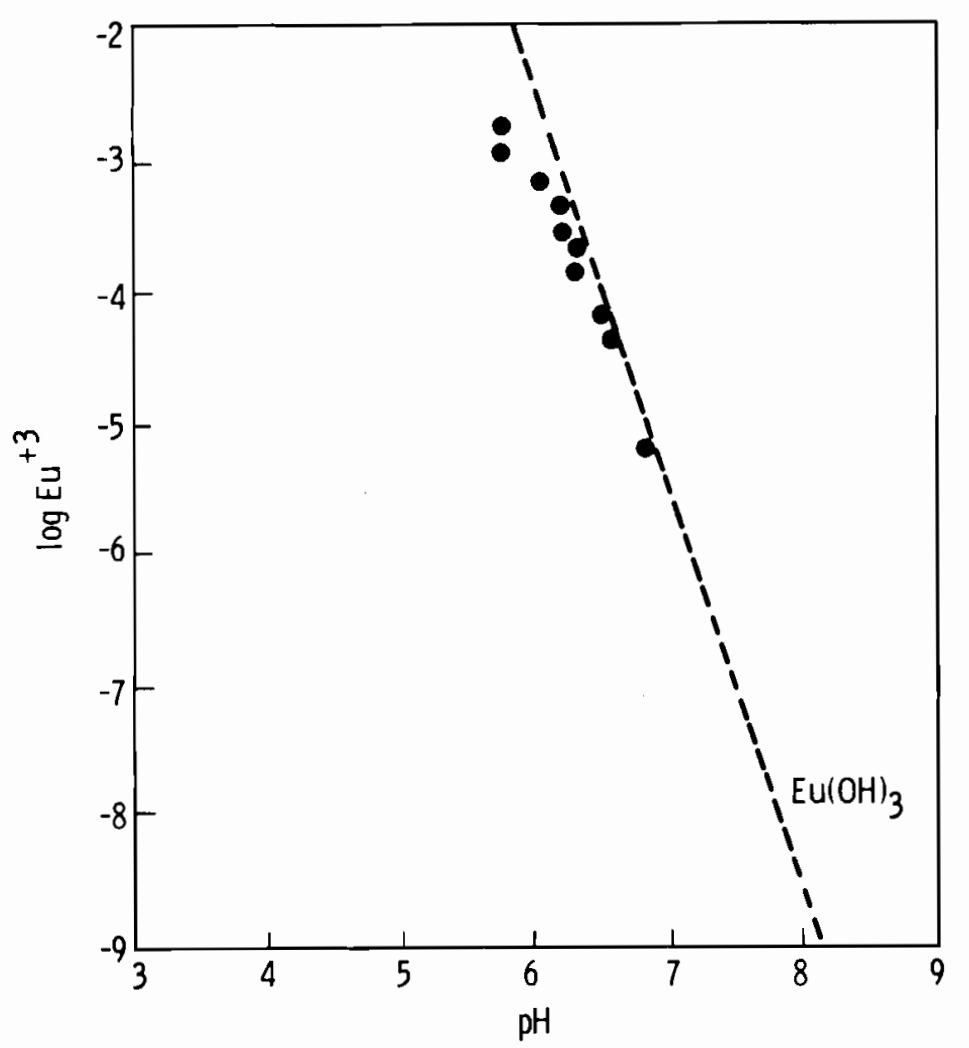

FIGURE 14. The Influence of $\mathrm{pH}$ on the Activity of Europium in Solution (Serne and Rai, 1976, Unpublished data) 
TABLE 9. Effect of pH and Europium Concentration on Europium Kd by Burbank Sand(a) (Serne and Rai, 1976)

\begin{tabular}{|c|c|c|c|c|c|c|c|c|}
\hline $\mathrm{Eu}, \mathrm{ppm}{ }^{(b)}$ & $\begin{array}{l}\text { Final } \\
\text { pH }\end{array}$ & $\begin{array}{r}\mathrm{Kd}, \\
\mathrm{mg} / \mathrm{l}\end{array}$ & $\underline{\mathrm{Eu}, \mathrm{ppm}^{(\mathrm{b})}}$ & $\begin{array}{l}\text { Final } \\
\mathrm{pH}\end{array}$ & $\begin{array}{r}\mathrm{kd}, \\
\mathrm{mg} / \mathrm{i}\end{array}$ & Eu, ppm (b) & $\begin{array}{l}\text { Final } \\
\mathrm{pH} \\
\end{array}$ & $\begin{array}{r}\mathrm{Kd}, \\
\mathrm{mg} / \mathrm{l}\end{array}$ \\
\hline 0 & 4.82 & 46 & 0.05 & 5.25 & 73 & 5.0 & 5.20 & 17.7 \\
\hline 0 & 4.82 & 48 & 0.05 & 5.30 & 83 & 5.0 & 5.20 & 15.9 \\
\hline 0 & 4.90 & 51 & 0.05 & 5.30 & 82 & 5.0 & 5.25 & 17.0 \\
\hline 0 & 5.00 & 75 & 0.05 & 5.30 & 84 & 5.0 & 5.32 & 20.0 \\
\hline 0 & 5.05 & 70 & 0.05 & 5.35 & 98 & 50.0 & 4.70 & 6.9 \\
\hline 0 & 5.05 & 69 & 0.5 & 4.75 & 28 & 50.0 & 4.70 & 6.9 \\
\hline 0 & 5.08 & 75 & 0.5 & 4.80 & 26 & 50.0 & 4.73 & 6.5 \\
\hline 0 & 5.10 & 84 & 0.5 & 4.80 & 27 & 50.0 & 4.88 & 5.8 \\
\hline 0 & 5.10 & 78 & 0.5 & 5.00 & 35 & 50.0 & 4.90 & 5.8 \\
\hline 0 & 5.10 & 78 & 0.5 & 5.05 & 35 & 50.0 & 4.90 & 5.9 \\
\hline 0 & 5.10 & 82 & 0.5 & 5.05 & 41 & 50.0 & 4.90 & 6.3 \\
\hline 0 & 5.10 & 75 & 0.5 & 5.10 & 42 & 50.0 & 4.90 & 6.2 \\
\hline 0 & 5.15 & 93 & 0.5 & 5.10 & 41 & 50.0 & 4.90 & 6.2 \\
\hline 0 & 5.15 & 90 & 0.5 & 5.10 & 42 & 50.0 & 5.00 & 7.2 \\
\hline 0 & 5.15 & 81 & 0.5 & 5.15 & 43 & 50.0 & 5.00 & 7.0 \\
\hline 0 & 5.15 & 93 & 0.5 & 5.15 & 45 & 50.0 & 5.00 & 7.1 \\
\hline 0 & 5.20 & 94 & 0.5 & 5.20 & 53 & 50.0 & 5.15 & 8.2 \\
\hline 0 & 5.20 & 98 & 0.5 & 5.20 & 48 & 50.0 & 5.15 & 8.2 \\
\hline 0 & 5.20 & 98 & 0.5 & 5.20 & 45 & 50.0 & 5.20 & 7.9 \\
\hline 0 & 5.25 & 107 & 0.5 & 5.25 & 48 & & & \\
\hline 0 & 5.30 & 106 & 0.5 & 5.25 & 57 & & & \\
\hline 0 & 5.30 & 97 & 0.5 & 5.30 & 54 & & & \\
\hline 0 & 5.50 & 153 & 0.5 & 5.35 & 60 & & & \\
\hline 0.05 & 4.75 & 32 & 5.0 & 4.80 & 12.4 & & & \\
\hline 0.05 & 4.75 & 38 & 5.0 & 4.80 & 11.3 & & & \\
\hline 0.05 & 4.80 & 38 & 5.0 & 4.80 & 12.4 & & & \\
\hline 0.05 & 5.00 & 63 & 5.0 & 4.95 & 16.9 & & & \\
\hline 0.05 & 5.00 & 53 & 5.0 & 5.00 & 18.4 & & & \\
\hline 0.05 & 5.00 & 53 & 5.0 & 5.05 & 15.7 & & & \\
\hline 0.05 & 5.08 & 56 & 5.0 & 5.05 & 14.8 & & & \\
\hline 0.05 & 5.08 & 62 & 5.0 & 5.10 & 15.9 & & & \\
\hline 0.05 & 5.10 & 67 & 5.0 & 5.10 & 18.7 & & & \\
\hline 0.05 & 5.25 & 71 & 5.0 & 5.15 & 16.4 & & & \\
\hline
\end{tabular}

(a) One gram samples free of $\mathrm{CaCO}_{3}$ and soluble salts were used.

(b) Various concentrations of Eu were added to $0.15 \mathrm{M} \mathrm{CaCl} 2$ solutions spiked with Eu152. Samples were equilibrated first for $48 \mathrm{hr}$ arid then for $24 \mathrm{hr}$ after adjusting the $\mathrm{pH}$. 
PREDICTED VS. OBSERVED BEHAVIOR OF EUROPIUM

No information on possible europium compounds in soils and sediments is available. Serne and Rai (1976) have shown that the kinetics of precipitation of $\mathrm{Eu}(\mathrm{OH})_{3}$ from pure solutions is rapid. The concentration of europium in equilibrium with $\mathrm{Eu}(\mathrm{OH})_{3}$ decreases 1000 -fold with an increase of one $\mathrm{pH}$ unit. The activity of europium in equilibrium with $\mathrm{Eu}(\mathrm{OH})_{3}$ is low under highly alkaline conditions and $\mathrm{Eu}(\mathrm{OH})_{3}$ may control europium concentration in alkaline soils and sediments.

Bensen (1960) and Baetsle and Dejonghe (1962) reported that europium appears to be taken up principally by ion exchange below pH 3. Baetsle and Dejonghe (1962) suggested that ion exchange was not the adsorption mechanism above $\mathrm{pH} 3$ because of europium hydrolysis. However, data presented in Figure 13 and the results of Serne and Rai (1976) are at variance with the above conclusion. Serne and Rai (1976) have shown that for meaningful determination of $\mathrm{Kd}$ values in soils, one must be below the solubility line of $\mathrm{Eu}(\mathrm{OH})_{3}$. Their results, thus obtained, showed that between $\mathrm{pH} 4.7$ and 5.5 the $\mathrm{Kd}$ decreases with an increase in $\mathrm{pH}$ and $\mathrm{Kd}$ decreases as europium concentration increases, which suggests an ion exchange as an adsorption mechanism. 


\section{IODINE}

Most of the compounds of iodine are very soluble. Some of the insoluble or sparingly soluble compounds include the iodides of $\mathrm{Pb}$ and $\mathrm{Pd}$, the hypoiodites of $\mathrm{Ag}$ and $\mathrm{Hg}$, and $\mathrm{Ba}$ periodates (Pourbaix, 1966). In normal soils the concentration of most of these elements ( $\mathrm{Pb}, \mathrm{Pd}, \mathrm{As}, \mathrm{Hg}$ and $\mathrm{Ba}$ ) with which iodine forms insoluble compounds with is very low. Therefore, they would not be expected to be present in soils.

Iodine can exist in $-1,+1,+3,+5$, and +7 oxidation states. Out of a 11 of these oxidation states, -1 ( $\mathrm{I}^{-}$, iodide) is the most important and its domain of predominance extends all along the $\mathrm{pH}$ scale, almost completely covering a large part of the stability domain of water (Pourbaix, 1966). Thus, it is not surprising that iodine in aqueous solutions free from oxidizing agents generally exists as iodide. 


\section{PREDICTED VS. OBSERVED BEHAVIOR OF IODINE}

Discrete iodine compounds would not be expected to be present in soils. Iodine in soil solutions would be present as iodide $\left(\mathrm{I}^{-}\right)$. Because the anion exchange capacities of most soils are minimal over a normal pH range of 6 to 8 , the adsorption of iodide $\left(\mathrm{I}^{-}\right)$, iodate $\left(\mathrm{IO}_{3}^{-}\right)$and organic-iodine molecules is normally also minimal (Wildung et al., 1975). However, with soils of low $\mathrm{pH}$ (4 to 6), the iodide $\mathrm{Kd}$ value can rise to $50 \mathrm{ml} / \mathrm{g}$. Wildung et al. (1975) reported no statistical correlation between organic content and iodide Kd, as they did for methyl iodide. The range of methyl iodide Kd values was from 0.1 to 3.1, much lower than the iodide ion Kd range, even though the correlation between methyl iodide Kd values and soil organic content was statistically significant. Others (Sinitskaya, 1969; Irinevich et a1., 1970; Pennington and Lishman, 1971) have shown a positive correlation between iodine content and organic material in the soil where the iodine is apparently covalently bonded to carbon (Walters and Winchester, 1971). It should be kept in mind that iodine, especially when present as an organic-iodine molecule, can change to a vapor phase and migrate much more rapidly than in an aqueous phase. 


\section{NEPTUNIUM}

The thermodynamic data are lacking for neptunium compounds other than oxide and hydroxides (Table 10). Figure 15 relates the activity of $\mathrm{NpO}_{2}^{+}$to $\mathrm{pH}$ under an oxidizing environment $\left(\mathrm{pO}_{2} 0.68\right)$ in equilibrium with neptunium oxide and hydroxides. Since Figure 15 was made using $\mathrm{Np}(\mathrm{V})\left(\mathrm{NpO}_{2}^{+}\right)$as the $y$ axis, the solubility of $\mathrm{Np}$ (IV) minerals would decrease and $\mathrm{Np}(\mathrm{VI})$ minerals would increase with an increase in reducing conditions. In an oxidizing environment $\left[\mathrm{pO}_{2(\mathrm{~g})}=0.68 \mathrm{~atm}\right]$ the solids in an increasing order of stability are $\mathrm{Np}(\mathrm{OH})_{4}, \mathrm{NpO}_{2}, \mathrm{NpO}_{2} \mathrm{OH}, \mathrm{NpO}_{2}(\mathrm{OH})_{2}$. Under the oxidation-reduction conditions represented by $\mathrm{pO}_{2}(\mathrm{~g})>3.8 \mathrm{~atm}, \mathrm{NpO}_{2}$ would be the most stable compound. Since $\mathrm{NpO}_{2}$ maintains very high concentrations of neptunium in solution, especially in acidic and very oxidizing environments, it is unlikely that $\mathrm{NpO}_{2}$ would be found as a discrete solid in such terrestrial environments. It may exist in very reducing conditions.

The activity of various solution complexes of neptunium in equilibrium with $\mathrm{NpO}_{2}(\mathrm{~s})$ under an oxidizing environment $\left(\mathrm{pO}_{2}=0.68\right)$ and assumed weathering environment is given in Figure 16. Thermodynamic data for different solution complexes of $\mathrm{Np}$ are give in Table 10. The solution complexes of $\mathrm{Np}$ (IV), $\mathrm{Np}(\mathrm{V})$, and $\mathrm{Np}(\mathrm{VI})$ in order of increasing importance are $\mathrm{Np}(\mathrm{IV})$, $\mathrm{Np}(\mathrm{VI})$, and $\mathrm{Np}(\mathrm{V})$. The activity of $\mathrm{Np}(\mathrm{IV})$ and $\mathrm{Np}(\mathrm{VI})$ complexes is so small that these complexes can be safely ignored since they would not contribute significantly to the total activity of $\mathrm{Np}$ in solution (Burney and Harbour, 1974). The lines of $\mathrm{Np}(\mathrm{V})$ and $\mathrm{Np}(\mathrm{VI})$ complexes will shift downward with the increase in reducing environment but still be parallel to the present lines. Under the conditions assumed in Figure $16, \mathrm{NpO}_{2}^{+}$is the most dominant solution species in a pH range of 0 to approximately 9 . Beyond $\mathrm{pH} 9, \mathrm{NpO}_{2} \mathrm{HPO}_{4}^{-}$and $\mathrm{NpO}_{2} \mathrm{HCO}_{3}{ }_{3}$ would control the total concentration of neptunium in solution.

$\mathrm{NpO}_{2}^{+}$is the usual form of charged neptunium species up to $\mathrm{pH} 9$. Above pH 9, an uncharged bicarbonate complex is formed. According to Keller (1971) and the data presented in Figure 16, neptunium (V) does not hydrolyze below a $\mathrm{pH}$ of 7 . Hence, a singly charged neptunyl ion would be expected to control geologic media interactions with neptunium. 


\section{TABLE 10. Selected Equilibrium Constants (K) at $25^{\circ} \mathrm{C}$ and One Atmosphere Pressure for Reactions Involving Neptunium}

\begin{tabular}{|c|c|c|c|c|}
\hline \multicolumn{2}{|c|}{ Reaction } & Medium (a) & \multirow[t]{2}{*}{$\log K$} & \multirow[t]{2}{*}{ Reference } \\
\hline \multicolumn{3}{|c|}{ SCLIU COAPOUNNOS } & & \\
\hline $\mathrm{Np}(\mathrm{OH})_{3}+3 \mathrm{e}^{-}$ & $\therefore \mathrm{Np}(\mathrm{s})+3 \mathrm{OH}^{-}$ & $1.0 \mathrm{NaOH}$ & -114.11 & Burney and Harbour (1974) \\
\hline $\mathrm{Np}(\mathrm{OH})_{4}$ & $\therefore \mathrm{Np}^{4+}+4 \mathrm{OH}^{-}$ & 0 & -55.22 & $"$ \\
\hline $\mathrm{NpO}_{2}(\mathrm{OH})$ & $\overrightarrow{+} \mathrm{NpO}_{2}^{+}+\mathrm{OH}^{-}$ & 0 & -9.09 & $"$ \\
\hline $\mathrm{NpO}_{2}\left(\mathrm{OH}_{2}\right)_{2}$ & $\therefore \mathrm{NpO}_{2}{ }^{2+}+2 \mathrm{OH}^{-}$ & $\hat{u}$ & -22.70 & $"$ \\
\hline $\mathrm{NpO}_{2}+4 \mathrm{H}^{+}$ & $=\mathrm{Np}^{4+}+2 \mathrm{H}_{2} \mathrm{O}$ & 0 & -2.68 & Keller (1971) \\
\hline
\end{tabular}

$$
\begin{aligned}
& \mathrm{Np}^{3+}+3 \overline{\mathrm{e}} \quad \therefore \mathrm{Np}(\mathrm{s}) \quad 0 \quad-94.13 \text { Burney and Harbour (1974) } \\
& \mathrm{Np}^{4+}+\mathrm{e}^{-} \quad \therefore \mathrm{Np}^{3+} \quad 0 \quad 2.57 \\
& \mathrm{NpO}_{2}^{+}+4 \mathrm{H}^{+}+\mathrm{e}^{-}: \mathrm{Np}^{4+}+2 \mathrm{H}_{2} \mathrm{O} \quad 0 \quad 12.66 \\
& \mathrm{NpO}_{2}{ }^{2+}+e^{-} \quad \mathrm{NpO}_{2}{ }^{+} \quad 0 \quad 19.42 \\
& \mathrm{NpO}_{2}{ }^{3+}+e^{-} \quad \mathrm{NpO}_{2}{ }^{2+} \quad 1.0 \mathrm{KOH} \quad 10.31 \text { Keller (1971) } \\
& \mathrm{Np}^{4+}+\mathrm{H}_{2} \mathrm{O} \quad \rightarrow \mathrm{NpOH}^{3+}+\mathrm{H}^{+} \quad 0 \quad-2.05 \text { Burney and Harbour (1974) } \\
& \mathrm{NpO}_{2}^{+}+\mathrm{H}_{2} \mathrm{O} \quad \because \mathrm{NpO}_{2} \mathrm{OH}^{\circ}+\mathrm{H}^{+} \quad 0 \quad-10.0 \\
& \mathrm{NpO}_{2}{ }^{2+}+\mathrm{H}_{2} \mathrm{O} \quad \therefore \mathrm{NpO}_{2} \mathrm{OH}^{+}+\mathrm{H}^{+} \quad 0 \quad-3.37 \\
& \text { OTHER REACTIONS }
\end{aligned}
$$

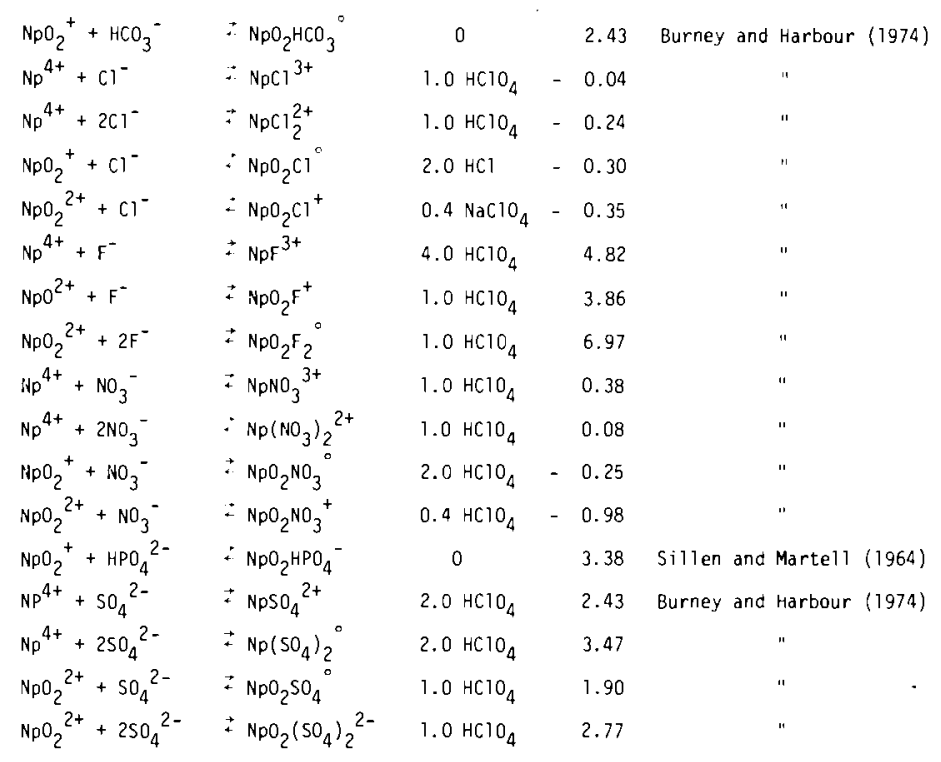

(a) The nature of the medium to which the equilibrium constants refer; for ewarle, 0 - zero ionic strength, var - ionic medium varied, $2\left(\mathrm{HClO}_{4}\right)$ - ionic strength helit $0 . \mathrm{stant}$ at the value stated (2 moles/2liter) by the addition of the chemical shown in parsutiluses, 1.0 $\mathrm{HClO}_{4}$ - constant concentration of the substance stated $(1.0$ moles/:liter $1 \mathrm{ic}(\mathrm{is})$. 


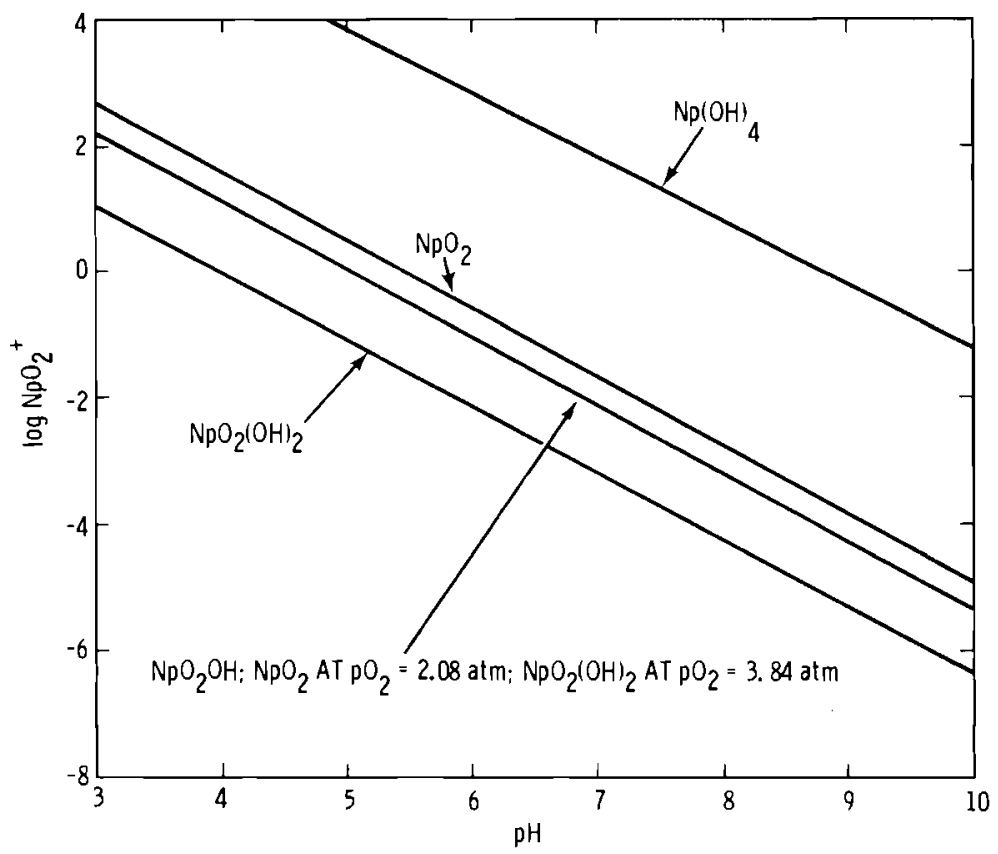

FIGURE 15. The Relative Stability of Various Neptunium Solids in an Oxidizing Soil Environment $\left[\mathrm{pO}_{2}(\mathrm{~g})=0.68 \mathrm{~atm}\right]$ 


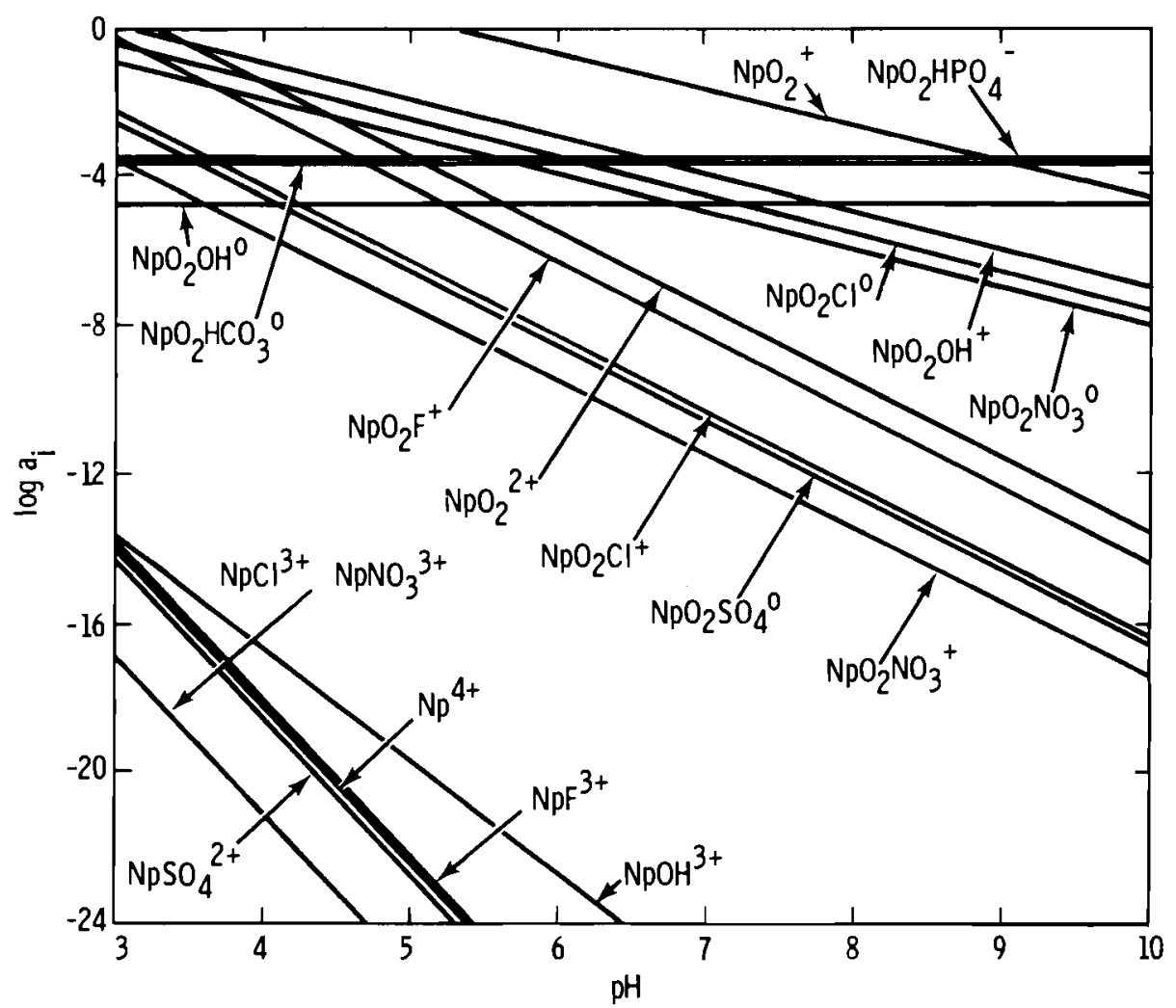

FIGURE 16. The Activity of Various Neptunium Species in Equilibrium with $\mathrm{NpO}_{2}(\mathrm{~s})$ under $\mathrm{pO}_{2}=0.68$, $\mathrm{pC}^{-}=\mathrm{pSO}_{4}^{-}=2.5, \mathrm{pNO}_{3}^{-}=3.0, \mathrm{pF}^{-}=4.5$ and $\mathrm{pH}_{2} \mathrm{PO}_{4}^{-}=5.0$ 
PREDICTED VS. OBSERVED BEHAVIOR OF NEPTUNIUM

The existing thermodynamic data (Figure 16) show that neptunium should exist in an oxidizing soil environment as $\mathrm{Np}(\mathrm{V})$ in the form of $\mathrm{NpO}_{2}^{+}$. However, existing adsorption results, essentially only a study by Routson et a1. (1975, 1976) and Sheppard et al. (1976), inferred that there is little evidence of $\mathrm{NpO}_{2}^{+}$ion exchange as a neptunium adsorption mechanism. Sheppard et al. (1976) reported neptunium colloids present in the soil-solution environment, while Routson et a1. (1975, 1976) specifically showed that they were absent from his solutions that had contacted soils. It is fairly certain that neptunium Kd values are generally low. Litte more can be said based on the adsorption and migration studies now available in the literature. Additional research is required on neptunium-soil and rock reactions. 


\section{PLUTONIUM}

The selected thermodynamic data for Plutonium compounds and solution species are reported in Table 11 . Figure 17 relates the activity of $\mathrm{Pu}^{4+}$ to $\mathrm{pH}$ in an oxidizing environment $\left[\mathrm{pO}_{2(\mathrm{~g})}=0.68 \mathrm{~atm}\right]$ in equilibrium with various Pu solid phases. Any solid in Figure 17 that lies below another solid, at a given $\mathrm{pH}$, is the more stable. Thus, for any two solid phases at a specific $\mathrm{pH}$, the solid that maintains lower $\mathrm{Pu}^{4+}$ activity is more stable. Under the assumptions outlined in Figure 17 and at $\mathrm{pH} 6$, the plutonium compounds in order of increasing stability are: $\mathrm{Pu}(\mathrm{OH})_{3} ; \mathrm{BPu}_{2} \mathrm{O}_{3} ; \mathrm{PuF}_{4} ; \mathrm{PuF}_{3}$; $\mathrm{Pu}\left(\mathrm{HPO}_{4}\right)_{2} ; \mathrm{PuO}_{2} \mathrm{OH} ; \mathrm{PuO}_{2} \mathrm{CO}_{3} ; \mathrm{Pu}(\mathrm{OH})_{4} ; \mathrm{PuO}_{2}(\mathrm{OH})_{2}$; and $\mathrm{PuO}_{2}$. Among the solids reported in Figure 15, $\mathrm{PuO}_{2}$ is the most stable mineral under oxidizing conditions at all $\mathrm{pH}$ values.

The stabilities of plutonium solid compounds in a reducing environment $\left[\mathrm{pO}_{2(\mathrm{~g})}=80 \mathrm{~atm}\right]$ are represented is Figure 18. In general, the reducing environment substantially changes the stabilities of the solids. Comparing Figures 17 and 18, it can be seen that the $\mathrm{Pu(IV)}$ solids remain unchanged, while $\mathrm{Pu}$ (III) solids increase and Pu(V and VI) solids decrease in their stabilities with the decrease in the oxygen pressure. Plutonium solids in the reducing environment at $\mathrm{pH} 6 \mathrm{can}$ be arranged in order of increasing stability as follows: $\mathrm{PuO}_{2}(\mathrm{OH})_{2} ; \mathrm{PuO}_{2} \mathrm{OH} ; \mathrm{PuF}_{4} ; \mathrm{Pu}\left(\mathrm{HPO}_{4}\right)_{2} ; \mathrm{Pu}(\mathrm{OH})_{3} ; \mathrm{BPu}_{2} \mathrm{O}_{3}$; $\mathrm{PuO}_{2}(\mathrm{OH})_{2}$; $\mathrm{PuF}_{3}$; and $\mathrm{PuO}_{2}$. $\mathrm{PuF}_{3}$ would be the most stable solid compound below $\mathrm{pH} 4$. Above this $\mathrm{pH}$ value, $\mathrm{PuO}_{2}$ would be the most stable solid (Figure 18). Based upon the Eh-pH diagrams for plutonium oxides, and hydroxides, Polzer (1971) predicted $\mathrm{PuO}_{2}(\mathrm{~s})$ to be the most stable solid phase under conditions generally found in the environment. However, the relative stabilities of $\mathrm{Pu}$ compounds other than hydroxides and oxides, and predictions regarding weathering sequences, were not considered by Polzer (1971).

Knowledge of the most stable compound present in the soil is necessary in order to predict the behavior or fate of the element in the soil. An extensive review on actinides indicated that numerous workers have studied the plutonium concentration and distribution with depth in soils. However, with the exception of Price and Ames (1975), none have made any attempt to 
identify the solid phases of plutonium present in soils. Price and Ames (1975) reported the presence of $\mathrm{PuO}_{2}$ under both alkaline and acidic oxidizing environments. Their observations were made approximately 20 years after the acidic radioactive waste was disposed to the alkaline soils. Tamura (1974) inferred the presence of $\mathrm{PuO}_{2}$ in aridisols or entisols from the Nevada Test Site. Thus, the Price and Ames, and Tamura results confirm theoretical predictions regarding the most stable plutonium compound expected to be present in soils. However, if the soil solution activity of plutonium is lower than the solubility product of $\mathrm{PuO}_{2}$ and any other possible compound, the final solution activities will depend mainly on the cation exchange processed and the coprecipitation of plutonium with other soil minerals.

Figure 19 demonstrates the activity of various plutonium species expected in equilibrium with $\mathrm{PuO}_{2}(\mathrm{~s})$ and in an oxidizing environment $\left(\mathrm{pO}_{2} 16\right.$ atm). Plutonium in solution exists in four oxidation states $\left(\mathrm{Pu}^{3+}, \mathrm{Pu}^{4+} \mathrm{PuO}_{2}^{+}\right.$, $\mathrm{PuO}_{2}^{2+}$ ) and forms complexes with $\mathrm{OH}^{-}, \mathrm{Cl}^{-}, \mathrm{F}^{-}, \mathrm{SO}_{4}^{2-}, \mathrm{H}_{2} \mathrm{PO}_{4}^{-}$and $\mathrm{CO}_{3}^{2-}$ ions. In general, the activity of all positively charged ions and ion-complexes and a few neutral ion-pairs decreases with the increase in $\mathrm{pH}$, while the activity of a 11 negatively charged ion-complexes increases with the increase in $\mathrm{pH}$. In an oxidizing environment, $\mathrm{Pu}^{3+}$ and $\mathrm{Pu}^{4+}$ and their ion-pairs have an insignificant effect on the total activity of plutonium in solution. At any given $\mathrm{pH}$, the total activity of plutonium in solution can be obtained by adding the appropriate activities of various plutonium species. Since the lines for some plutonium species are based on concentration constants, the position of the lines may change when converted to thermodynamic equi1 ibrium constants. Figures 19 and 20 were constructed by assuming a weathering environment $\left(\mathrm{pCO}_{2}=3.52 ; \mathrm{pCl}^{-}=\mathrm{pSO}_{4}^{2-}=2.5 ; \mathrm{pF}^{-}=3.5\right)$ and $\mathrm{PuO}_{2}(\mathrm{~s})$ as the compound that may be present in the soil at equilibrium. When diagrams are constructed for an actual weathering environment of a given soil, all the organic and inorganic ligands present in the soil solution should be considered. Figures 19 and 20 were developed for selected inorganic ligands only. 
Figure 20 relates the activities $\left(a_{i}\right.$, moles/liter) of various solution species at $\mathrm{pH} 8$ to the oxidation potential as represented by the various oxygen pressures. In general, with a decrease in oxygen pressure (increase in reducing conditions), the kind of activity of the solution species changes: 1) $\mathrm{Pu}^{3+}$ species increase in activity; 2) $\mathrm{Pu}^{4+}$ species are unaffected; and 3) $\mathrm{PuO}_{2}^{+}$and $\mathrm{PuO}_{2}^{2+}$ species decrease in activity. However, in doing so, the total activity of plutonium in solution at any given $\mathrm{pH}$ would not change significantly because the activity of species for which thermodynamic equilibrium constants are known is very large as compared to the others. When the concentration constants are converted to thermodynamic constants, the new lines would shift downward or upward but remain parallel to the present lines. The activities of various species would still vary in the same direction with the changes in $\mathrm{pH}$ as reported in Figure 19.

A few of the reactions are not plotted in the figures because either the activities of the species fall beyond the graph boundaries or the equilibrium constant data are not reliable. Cleveland (1970) suggested that the values for the formation constants of $\mathrm{PuCO}_{3}^{2+}$ and $\mathrm{Pu}(\mathrm{OH})_{4}^{\circ}$ were suspect; the values for $\mathrm{PuO}_{2}(\mathrm{OH})_{3}, \mathrm{PuO}_{2}^{0}\left(\mathrm{O}_{2}{ }^{\circ}\right.$, and $\mathrm{PuO}_{2} \mathrm{OH}^{+}$should be viewed with skepticism; and the value for $\mathrm{PuO}_{2} \mathrm{OH}^{\circ}$ should be considered only approximate. Under the assumptions of Figure 19 , the lines for $\mathrm{Pu}(\mathrm{OH})_{4}^{\circ}$ and $\mathrm{PuO}_{2}(\mathrm{OH})_{2}^{\circ}$ would be parallel to the $X$-axis with $10^{-12.51}$ and 10-19.16 moles/e activity, respectively. Many researchers (Andelman and Rozze11, 1970; Fukai and Murray, 1974; Grebenshchikova and Davydov, 1961, 1965; Sheidina and Kovarskaya, 1970) have reported that plutonium in solution also exists as colloidal species over a wide $\mathrm{pH}$ range. Colloidal species and neutral ion-complexes $\left[\mathrm{Pu}(\mathrm{OH})^{\circ}{ }_{4}\right.$, $\mathrm{PuO}_{2}(\mathrm{OH})_{2}^{\circ}$ ] are not reported in Figures 19 and 20 . If present in large quantities, these species would significantly influence the nature of the species and the total concentration of plutonium in solutions.

For the conditions specified in Figure 19, the dominant plutonium species in low and high $\mathrm{pH}$ ranges are $\mathrm{PuO}_{2}^{+}$and $\mathrm{PuO}_{2} \mathrm{CO}_{3} \mathrm{OH}^{-}$, respectively. The colloid complex of soils is mainly negatively charged. Therefore, positively charged species are usually absorbed by soils in cation exchange processes. Since positively charged $\mathrm{PuO}_{2}^{+}$species predominate only in solutions of $\mathrm{pH}$ values 
$<6$, cation exchange adsorption of plutonium by soils would be limited to acidic soils $(\mathrm{pH}<6)$. The negatively charged $\mathrm{PuO}_{2} \mathrm{CO}_{3} \mathrm{OH}^{-}$complex that predominates above $\mathrm{pH} 8$ [even when the activity of $\mathrm{PuO}_{2} \mathrm{CO}_{3} \mathrm{OH}^{-}$is compared to $\mathrm{Pu}(\mathrm{OH})_{4}^{\circ}$ ] should not be readily adsorbed by the soils. Thus, the activity of plutonium in soil solutions of $\mathrm{pH}>8$ would be relatively high because of: 1) little soil adsorption of negatively charged ions; and 2) increases in the activities of negatively charged ions with the increase in $\mathrm{pH}$. Similarly, under extremely low pH conditions the activity of plutonium in soil solutions in equilibrium with $\mathrm{PuO}_{2}$ (s) may also be high. Rhodes (1957a) found low adsorption of plutonium by soils in the $\mathrm{pH}$ range of approximately $<2$ and 8 to 13 . Thus, his results confirm part of the predictions based on Figure 19; continuous decrease in adsorption is predicted with the increase in $\mathrm{pH}$ above 8 , whereas Rhodes' data indicated first a decrease in adsorption to $\mathrm{pH} 12$ and then an unexplained continuous increase in adsorption above $\mathrm{pH} 12$. 

TABLE 11. Selected Equilibrium Constants $(\mathrm{K})$ at $25^{\circ} \mathrm{C}$ and 1 atm Pressure
for Reactions Involving Plutonium

Reaction

\begin{tabular}{|c|c|c|}
\hline & Reaction & Medium' \\
\hline & Solid & Compounds \\
\hline $\mathrm{PuO}_{2}+4 \mathrm{H}^{+}$ & 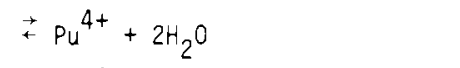 & 0 \\
\hline $\mathrm{Pu}_{2} \mathrm{O}_{3}(\beta)+6 \mathrm{H}^{+}$ & $\rightleftarrows 2 \mathrm{Pu}^{4+}+3 \mathrm{H}_{2} \mathrm{O}+2 \overline{\mathrm{e}}$ & 0 \\
\hline $\mathrm{Pu}(\mathrm{OH})_{3} \times \mathrm{H}_{2} \mathrm{O}$ & $\rightarrow \mathrm{Pu}^{3+}+3 \mathrm{OH}^{-}+\mathrm{xH}_{2} \mathrm{O}$ & 0 \\
\hline $\mathrm{Pu}(\mathrm{OH})_{4} \mathrm{xH}_{2} \mathrm{O}$ & 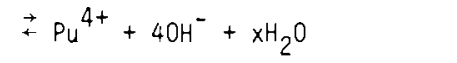 & 0 \\
\hline $\mathrm{PuO}_{2} \mathrm{OH}$ & $\pm \mathrm{PuO}_{2}^{+}+\mathrm{OH}^{-}$ & 0 \\
\hline $\mathrm{PuO}_{2}(\mathrm{OH})_{2}$ & 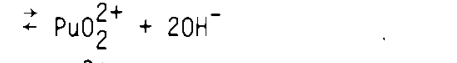 & 0 \\
\hline $\mathrm{PuCl}_{3}$ & $\rightleftarrows \mathrm{Pu}^{3+}+3 \mathrm{Cl}^{-}$ & 0 \\
\hline $\mathrm{PuO}_{2} \mathrm{CO}_{3}$ & 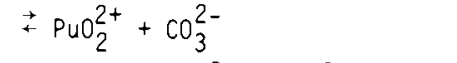 & 1.0 \\
\hline$\left(\mathrm{NH}_{4}\right)_{2} \mathrm{PuO}_{2}\left(\mathrm{CO}_{3}\right)_{2}$ & $\rightleftarrows 2 \mathrm{NH}_{4}^{+}+\mathrm{PuO}_{2}^{2+}+2 \mathrm{CO}_{3}^{2-}$ & 1.0 \\
\hline $\mathrm{PuF}_{3}$ & $\stackrel{+}{+} \mathrm{Pu}^{3+}+3 \mathrm{~F}^{-}$ & 0 \\
\hline $\mathrm{PuF}_{4}$ & $\rightarrow \mathrm{Pu}^{4+}+4 \mathrm{~F}^{-}$ & 0 \\
\hline $\mathrm{Pu}\left(\mathrm{HPO}_{2}\right)_{2} \times \mathrm{H}_{2} \mathrm{O}$ & $\stackrel{+}{+} \mathrm{Pu}^{4+}+2 \mathrm{HPO}_{4}^{2-}+x \mathrm{H}_{2} \mathrm{O}$ & 0 \\
\hline $\mathrm{K}_{4} \mathrm{Pu}\left(\mathrm{SO}_{4}\right)_{4} 2 \mathrm{H}_{2} \mathrm{O}$ & 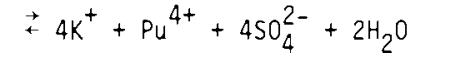 & 0 \\
\hline
\end{tabular}

Oxidation-Reduction Reactions $\log K$

$-6.50^{(b)}$

$11.59^{(b)} \quad$ Cleveland (1970); and

$-19.7$

$-55.15$

$-9.30$

$-24.52$

$11.44^{(b)}$

$-12.77$

$-1.33$

$-15.6$

$-19.22$

$-27.7$

$-18.0$

Reference Keller (1971)

Cleveland (1970)

Cleveland (1970)

Sillen and Martell

Cleveland (1970)

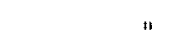

Keller (1971)

Sillen and Martell (1964)

(1964)

-103.0
16.37
$19.50^{(b)}$
15.7

Hydrolysis Reactions

$\begin{array}{ll}\mathrm{Pu}^{3+}+\mathrm{H}_{2} \mathrm{O} & \pm \mathrm{PuOH}^{2+}+\mathrm{H}^{+} \\ \mathrm{Pu}^{4+}+\mathrm{H}_{2} \mathrm{O} & \pm \mathrm{PuOH}^{3+}+\mathrm{H}^{+} \\ \mathrm{Pu}^{4+}+4 \mathrm{H}_{2} \mathrm{O} & \mp \mathrm{Pu}(\mathrm{OH})_{4}^{\circ}+4 \mathrm{H}^{+} \\ \mathrm{PuO}_{2}^{+}+\mathrm{H}_{2} \mathrm{O} & \mp \mathrm{PuO}_{2} \mathrm{OH}^{\circ}+\mathrm{H}^{+} \\ \mathrm{PuO}_{2}^{2+}+\mathrm{H}_{2} \mathrm{O} & \mp \mathrm{PuO}_{2} \mathrm{OH}^{+}+\mathrm{H}^{+} \\ \mathrm{PuO}_{2} \mathrm{OH}^{+}+\mathrm{H}_{2} \mathrm{O} & \pm \mathrm{PuO}_{2}(\mathrm{OH})_{2}^{\circ}+\mathrm{H}^{+} \\ \mathrm{PuO}_{2}(\mathrm{OH})_{2}{ }^{\circ}+\mathrm{H}_{2} \mathrm{O} & \mp \mathrm{PuO}_{2}(\mathrm{OH})_{3}^{-}+\mathrm{H}^{+} \\ 2 \mathrm{PuO}_{2}^{2+}+3 \mathrm{H}_{2} \mathrm{O} & \mp\left(\mathrm{PuO}_{2}\right)_{2}(\mathrm{OH})_{3}^{+}+3 \mathrm{H}^{+} \\ 2 \mathrm{PuO}_{2}^{2+}+5 \mathrm{H}_{2} \mathrm{O} & \mp\left(\mathrm{PuO}_{2}\right)_{2}(\mathrm{OH})_{5}^{-}+5 \mathrm{H}^{+} \\ 2 \mathrm{PuO}_{2}^{2+}+2 \mathrm{H}_{2} \mathrm{O} & \rightleftarrows\left(\mathrm{PuO}_{2}\right)_{2}(\mathrm{OH})_{2}^{2+}+2 \mathrm{H}^{+}\end{array}$

$-6.95$

$-\quad 1.27$

$2.0\left(\mathrm{ClO}_{4}^{-}\right)$

$3.5(\mathrm{KCT})$ at $20^{\circ} \mathrm{C}$

$-6.01^{(b)}$

\begin{tabular}{l}
-9.7 \\
\hline
\end{tabular}

$-5.30$

-5.71
-50

\begin{tabular}{l}
-9.70 \\
\hline
\end{tabular}

Var at $20^{\circ} \mathrm{C}$

- 6.28

$-22.10$

$-8.51$
Sillen and Martell (1964)

Sillen and Martell (1964)

Cleveland (1970)

$"$

$"$

Sillen and Marte17 (1964)

Cassol et al. (1972) 


\section{TABLE 11. (Continued)}

\section{Medium $(a)$}

$\underline{\log }$

\section{Other Reactions}

\begin{tabular}{|c|c|c|c|c|}
\hline $\mathrm{Pu}^{4+}+\mathrm{CO}_{3}^{2-}$ & $\stackrel{\rightarrow}{\mathrm{PuCO}_{3}^{2+}}$ & $10.0(\mathrm{KCl})$ at $20^{\circ} \mathrm{C}$ & 46.96 & Sillen and Martell (1964) \\
\hline $\mathrm{PuO}_{2}^{2+}+\mathrm{CO}_{3}^{2-}$ & $+\mathrm{PuO}_{2} \mathrm{CO}_{3} \mathrm{O}$ & 1.0 & 12.0 & " \\
\hline $\mathrm{PuO}_{2}^{2+}+2 \mathrm{CO}_{3}^{2-}$ & $\stackrel{\mathrm{PuO}_{2}}{ }\left(\mathrm{CO}_{3}\right)_{2}^{2-}$ & 0 & 15.04 & Cleveland (1970) \\
\hline $\mathrm{PuO}_{2}^{2+}+3 \mathrm{CO}_{3}^{2-}$ & $\rightarrow \mathrm{PuO}_{2}\left(\mathrm{CO}_{3}\right)_{3}^{4-}$ & 1.0 & 2.09 & Sillen and Martell (1964) \\
\hline $\mathrm{PuO}_{2}^{2+}+\mathrm{CO}_{3}^{2-}+\mathrm{OH}^{-}$ & 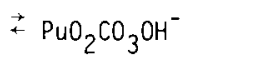 & 0 & 23.85 & Cleveland $(1970)$ \\
\hline $\mathrm{PuO}_{2}^{2+}+\mathrm{CO}_{3}^{2-}+2 \mathrm{OH}^{-}$ & 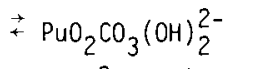 & 0 & 23.0 & $"$ \\
\hline $\mathrm{Pu}^{3+}+\mathrm{HCl}$ & 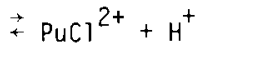 & 0 & -2.4 & $"$ \\
\hline $\mathrm{Pu}^{4+}+\mathrm{Cl}^{-}$ & $\rightarrow \mathrm{PuCl}^{3+}$ & 1.0 & 0.15 & Keller (1971) \\
\hline $\mathrm{PuO}_{2}^{+}+\mathrm{Cl}^{-}$ & $\stackrel{\mathrm{PuO}_{2} \mathrm{Cl}}{\circ}$ & 0 & -0.17 & Sillen and Martell (1964) \\
\hline $\mathrm{PuO}_{2}^{2+}+\mathrm{Cl}^{-}$ & $\rightleftarrows \mathrm{PuO}_{2} \mathrm{Cl}^{+}$ & 2.0 & 0.10 & Cleveland (1970) \\
\hline $\mathrm{PuO}_{2} \mathrm{Cl}^{+}+\mathrm{Cl}^{-}$ & $\stackrel{+}{+} \mathrm{PuO}_{2} \mathrm{Cl}_{2}^{\circ}$ & 2.0 & -0.45 & $"$ \\
\hline $\mathrm{Pu}^{4+}+\mathrm{F}^{-}$ & $\rightarrow \mathrm{PuF}^{3+}$ & 0 & 7.94 & Sillen and Martell (1964) \\
\hline $\mathrm{Pu}^{4+}+\mathrm{NO}_{3}^{-}$ & $\stackrel{\mathrm{PuNO}_{3}^{3+}}{3+}$ & 1.02 & 0.72 & Keller (1971) \\
\hline $\mathrm{Pu}^{4+}+\mathrm{HPO}_{4}^{2-}$ & 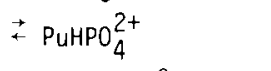 & $2.0 \mathrm{HNO}_{3}$ & 12.92 & Sillen and Martell (1964) \\
\hline $\mathrm{PuHPO}_{4}^{2+}+\mathrm{HPO}_{4}^{2-}$ & $\rightleftarrows \mathrm{Pu}\left(\mathrm{HPO}_{4}\right)_{2}^{\circ}$ & $2.0 \mathrm{HNO}_{3}$ & 10.82 & $"$ \\
\hline $\mathrm{PuO}_{2}^{2+}+\mathrm{H}_{2} \mathrm{PO}_{4}^{-}$ & $\stackrel{\mathrm{PuO}_{2}}{ }\left(\mathrm{H}_{2} \mathrm{PO}_{4}\right)^{+}$ & $\operatorname{Var}(0.02-0.206)$ & 3.93 & Cleveland (1970) \\
\hline $\mathrm{Pu}^{3+}+\mathrm{SO}_{4}^{2-}$ & $\rightleftarrows \mathrm{PuSO}_{4}^{+}$ & $1.0\left(\mathrm{H}^{+}\right)$ & 1.26 & $"$ \\
\hline $\mathrm{Pu}^{3+}+2 \mathrm{HSO}_{4}^{-}$ & $\rightleftarrows \mathrm{Pu}\left(\mathrm{HSO}_{4}\right)_{2}^{+}$ & $1.0\left(\mathrm{H}^{+}\right)$ & 1.0 & $"$ \\
\hline $\mathrm{Pu}^{4+}+\mathrm{HSO}_{4}^{-}$ & 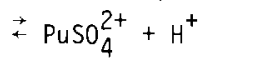 & 0.5 & 0.98 & $"$ \\
\hline $\mathrm{Pu}^{4+}+2 \mathrm{HSO}_{4}^{-}$ & $\stackrel{\mathrm{Pu}}{ }\left(\mathrm{SO}_{4}\right)_{2}^{\circ}+2 \mathrm{H}^{+}$ & 0.5 & 1.30 & $"$ \\
\hline $\mathrm{Pu}^{4+}+3 \mathrm{HSO}_{4}^{-}$ & 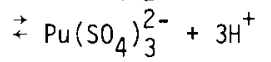 & 0.5 & 2.10 & $"$ \\
\hline
\end{tabular}

(a) The nature of the medium to which the equilibrium constants refer, for example, 0 - zero ionic strength, var - ionic medium varied, $2\left(\mathrm{HClO}_{4}\right)$ - ionic strength held constant at the value stated ( 2 moles/iliter) by the addition of the chemical shown in parentheses, 1.0 $\mathrm{HClO}_{4}$ - constant concentration of the substance stated $\left(1.0\right.$ moles/le 1 iter $\left.\mathrm{HClO}_{4}\right)$.

(b) These equilibrium constants were calculated from the data in the given reference and the other appropriate data included in the tables or given in standard references.

Reference 


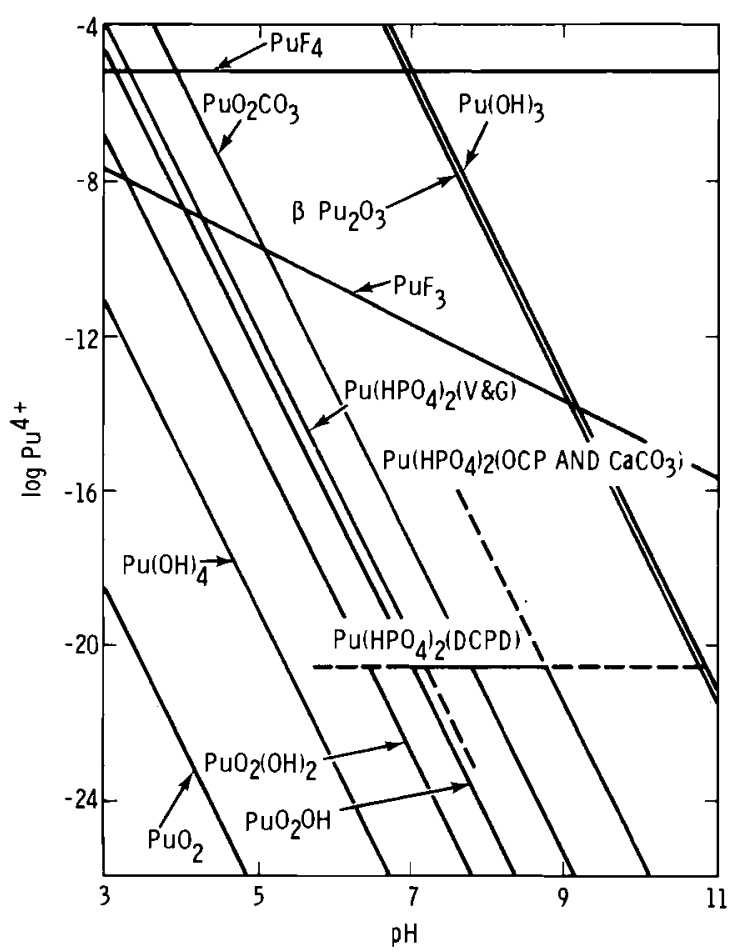

FIGURE 17. The Relative Stability of Plutonium Solids Under $\mathrm{pO}_{2}=0.68, \mathrm{pCO}_{2}=3.52$, $\mathrm{pF}^{-}=3.5$ and Phosphate Levels in Equilibrium with Variscite and Gibbsite ( $V$ and $G)$, Dicalcium Phosphate Dihydrate (DCPD) and Octacalcium Phosphate (OCP) (Rai and Serne, 1977) 


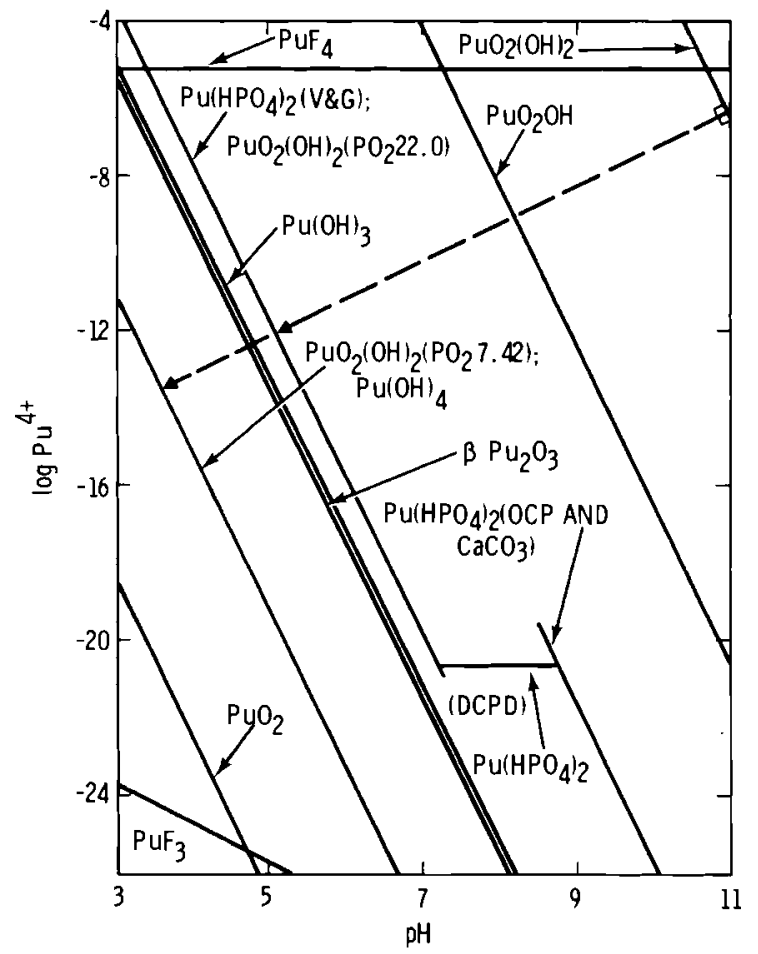

FIGURE 18. The Relative Stability of Various Plutonium Solids in Reducing Environments $\left(\mathrm{pO}_{2}=80\right), \mathrm{pCO}_{2}=3.52, \mathrm{pF}^{-}=3.5$, and Phosphate Levels in Equilibrium with Variscite and Gibbsite (V and G), Dicalcium Phosphate Dihydrate (DCPD) and Octacalcium Phosphate (OCP) (Rai and Serne, 1977) 


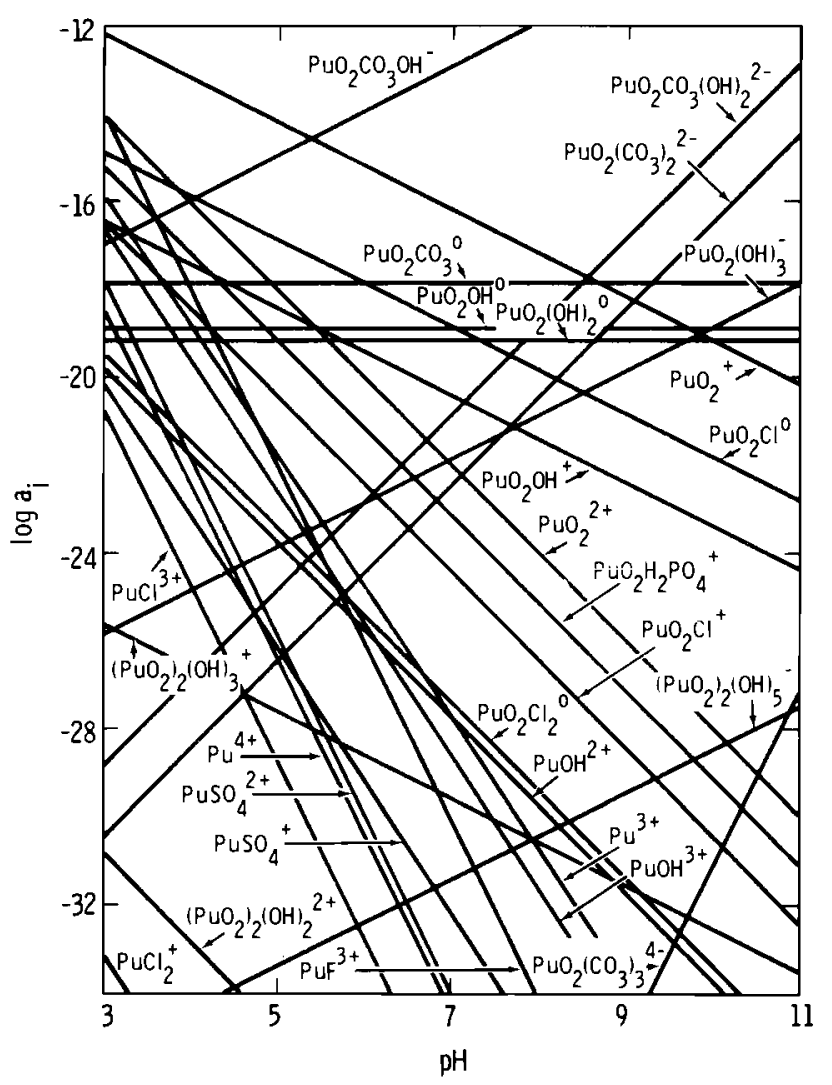

FIGURE 19. The Activity of Various Plutonium Species in Equilibrium with $\mathrm{PuO}_{2}$ (s) Under $\mathrm{pO}_{2}=16, \mathrm{pCO}_{2}=3.52, \mathrm{pC}^{-}=$ 2.5, $\mathrm{pF}^{-}=3.5$, and $\mathrm{pH}_{2} \mathrm{PO}_{4}^{-}=5.0$ (Rai and Serne, 1977) 


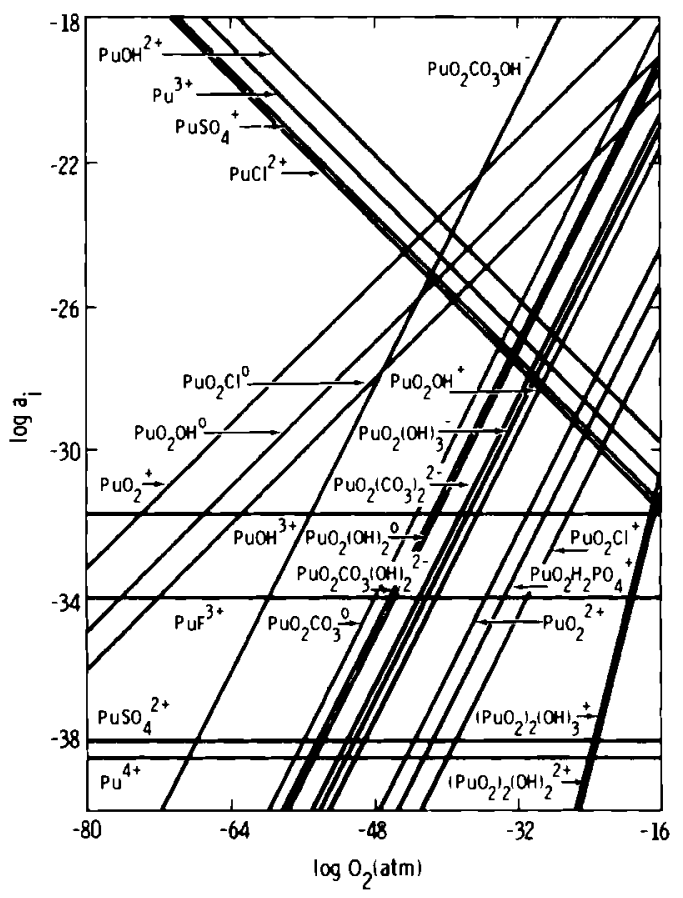

FIGURE 20. The Activity of Various Plutonium Species in Equilibrium with $\mathrm{PuO}_{2}$ (s) at $\mathrm{pH} 8, \mathrm{pCO}_{2}=3.52, \mathrm{pCl}^{-}=\mathrm{pSO} 2-=$ 2.5, and $\mathrm{pH}_{2} \mathrm{PO}_{4}^{-}=5.0$ ( $\mathrm{Ra} i$ and Serne, 1977) 
PREDICTED VS. OBSERVED BEHAVIOR OF PLUTONIUM

In most oxidizing environments, ionic plutonium is expected to be present in solution predominantly as $\mathrm{Pu}(\mathrm{V})$ or Pu(VI) (Figures 19 and 20). With high plutonium concentrations, $\mathrm{PuO}_{2}$ could be expected as a stable solid phase (Figures 17 and 18). The plutonium adsorption data indicate that more than one mechanism is operating during reactions with rocks and soils. There is a direct correlation of plutonium adsorption results with soil cation exchange capacities (Thorburn, 1950; Evans, 1956; Rhodes, 1952, 1957a, 1957b; Van Dalen et al., 1975; Glover et a1., 1977) indicating that part of the adsorption is due to ion exchange. However, little effect on adsorption was obvious from competing cation concentrations that were very high (Rhodes, 1957a; Mo and Lowman, 1975). Perhaps the principal correlation of plutonium adsorption is with pH (Rhodes, 1952, 1957a, 1957b; Knol1, 1965; Hajek and Knol1, 1966; Knol1, 1969). A relatively rapid soil column breakthrough of plutonium was obtained with a low $\mathrm{pH}(<1)$ solution (Knol1, 1965). Strong adsorption occurs over the pH range of from 4 to 8 (Prout, 1958, 1959), but above $\mathrm{pH} 8$ the formation of negative complexes or polymers with low charge densities can cause lowered adsorption (Thorburn, 1950; Rhodes, 1957a; Polzer and Miner, 1977). In addition, plutonium is easily complexed with humic acids (Desai and Ganguly, 1970; Bondietti et a1., 1975) and with oxalate (Bensen, 1960), acetate (Rhodes, 1957a) and a large number of phosphorusbearing organics used in the nuclear fuels reprocessing industry (Knol1, 1969). Complexed plutonium also can result from soil fungal or microbial activities (Wildung et a1., 1973, 1977; Au, 1974) all of which result in more mobile plutonium. Even the precipitated or adsorbed plutonium can be readily moved through the aqueous environments in the form of particulates or suspended sediments (Magno et a1., 1970; Emery et a1., 1974a, 1974b, 1975; Meyer, 1975; Montgomery et a1., 1977). If the Eh environment allows it, Pu(IV) can be oxidized to $\mathrm{Pu}(\mathrm{V})$ or (VI), with much lower plutonium adsorption values resulting (Bondietti, 1974). The plutonium polymers usualiy are adsorbed readily, but can migrate more rapidly than soluble plutonium in some instances where the surface charge density is low (Friedman et a1., 1977). Much experimental 
work remains to be done to separate and understand the several reactions mechanisms occurring in plutonium adsorption on rocks or soils. A controlled Eh environment for the adsorption work is important as an experimental condition when an element disproportionates as readily as plutonium. 


\section{PROMETHIUM}

Promethium forms crystalline compounds with $\mathrm{F}^{-}, \mathrm{Cl}^{-}, \mathrm{Br}^{-}, \mathrm{I}, \mathrm{OH}^{-}, \mathrm{PO}_{4}{ }^{3-}$, $\mathrm{AsO}_{4}{ }^{3-}, \mathrm{BO}_{3}{ }^{3-}, \mathrm{CrO}_{4}, \mathrm{CrO}_{3}, \mathrm{MoO}_{4}{ }^{2-}, \mathrm{WO}_{4}{ }^{2-}, \mathrm{VO}_{4}{ }^{3-}, \mathrm{ScO}_{3}{ }^{3-}$ (Lavrukhina and Pozdnyakov, 1970; Wheelwright, 1973). However, the thermodynamic data are only available for $\mathrm{Pm}(\mathrm{OH})_{3} \rightleftarrows \mathrm{Pm}^{3+}=30 \overline{\mathrm{H}}$ with $\log \mathrm{K}^{\circ}$ of -34 (Sillen and Marte11, 1964) and for $\mathrm{Pm}_{2} \mathrm{O}_{3}+6 \mathrm{H}^{+} \stackrel{3}{\leftarrow} 2 \mathrm{Pm}^{3+}+3 \mathrm{H}_{2} \mathrm{O}$ with $\mathrm{log} \mathrm{K}^{\circ}$ of 42.04 (Pourbaix, 1966). It is evident that $\mathrm{Pm}(\mathrm{OH})_{3}$ is more stable than $\mathrm{Pm}_{2} \mathrm{O}_{3}$ (Figure 21). The $\mathrm{Pm}^{3+}$ activity in equilibrium with $\mathrm{Pm}(\mathrm{OH})_{3}$ decreases a thousand-fold with a one unit increase in $\mathrm{pH}$.

Promethium is a lanthanide and like most lanthanides exists in a trivalent state $\left(\mathrm{Pm}^{3+}\right)$. No data were found on solution species of promethium except for $\mathrm{PmNO}_{3}^{2+}\left(\mathrm{Pm}^{3+}+\mathrm{NO}_{3}^{-} \rightleftarrows \mathrm{PmNO}_{3}^{2+} \log \mathrm{K}^{\circ}\right.$ at $\mathrm{I}=1$ is 2.48) (Lavrukhina and Pozdnyakov, 1970). The solution species is probably predominantly $\mathrm{Pm}^{3+}$, much like europium. If it is assumed that promethium does not form any other complexes, then the concentration of promethium in solution will be governed mainly by $\mathrm{Pm}^{3+}$. Under these conditions, ion exchange can be an important promethium removal mechanism in acidic environments and at trace promethium concentrations. 


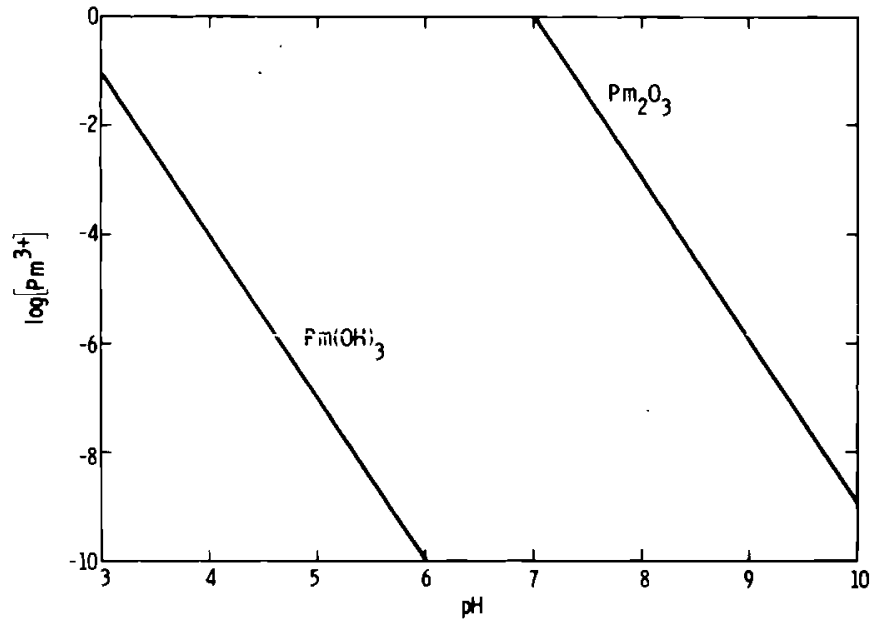

FIGURE 21. The Relative Stability of Various Promethium Solids 
PREDICTED VS. OBSERVED BEHAVIOR OF PROMETHIUM

Low concentrations of promethium are expected in equilibrium with $\mathrm{Pm}(\mathrm{OH})_{3}$ in slightly acidic to slightly alkaline conditions (Figure 21) so that $\mathrm{Pm}(\mathrm{OH})_{3}$ precipitation may control promethium concentrations in soil and sediment solutions. Promethium, like europium, would be expected to be ion exchangeable below the concentration required for $\mathrm{Pm}(\mathrm{OH})_{3}$ precipitation. Only limited data are available on promethium adsorption on soils and sediments, but these data tend to support the above predictions.

The removal of promethium is nearly complete on soils and rocks above pH 6 (Bensen, 1960). The effect of competing cations on promethium adsorpticn above $\mathrm{pH} 7$ is minimal. Below pH 3, the adsorption of all rare earths including promethium are similarly depressed by competing salts. Charged polymers can form under the proper conditions during $\mathrm{Pm}(\mathrm{OH})_{3}$ precipitation (Starik et a1., 1959; Bensen, 1960). Citrate, acetate and carbonate ions inhibited rare earth adsorption on soils, probably due to the formation of complex ion species. Over $90 \%$ of the promethium discharged to a lagoon system remained in the lagoon (Magno et al., 1970) as strongly adsorbed on clily particles or present as an insoluble hydroxide (Schulz, 1965). Promethium can be removed from solution during replacement reactions (Ames, 1960). 


\section{RADIUM}

The thermodynamic data for radium compounds are available only for radium nitrate, chloride, iodate and sulfate (Parker et a1., 1971). However, all of the compounds except sulfate are very soluble. Therefore, solid phase diagrams are not presented for radium compounds. The solubility product for $\mathrm{RaSO}_{4}$ is $10^{-10.37}$ compared to $10^{-9.96}$ for $\mathrm{BaSO}_{4}$.

No thermodynamic data were located for radium hydrolysis or complex ion species. It is expected the radium will behave in the soil solution much like strontium does. The species $\mathrm{Ra}^{2+}$ is expected to be the most important over the normal soil $\mathrm{pH}$ range from 4 to 8 . 


\section{PREDICTED VS. OBSERVED BEHAVIOR OF RADIUM}

Radium is present as $\mathrm{Ra}^{2+}$ over the normal soil $\mathrm{pH}$ range (4 to 8 ) and shows little tendency to form complex species (Schubert et al., 1950). Radium would be expected to substitute for other divalent cations during replacement or precipitation reactions (Granger et al., 1961; Granger, 1963). A direct correlation of cation exchange capacity with adsorption (Arnold and Crouse, 1965) and leaching studies with different types of competing cations (Starik and Polevaya, 1958; Starik and Lazerev, 1960; Shearer, 1962; Shearer and Lee, 1964; Havlik et al., 1968b) suggests that an important reaction mechanism for radium adsorption is cation exchange. Radium could be expected to migrate in much the same manner as strontium. 


\section{RUTHENIUM}

Ruthenium is generally present in association with platinum group metals. It forms discrete solid compounds such as $\mathrm{RuO}_{2}, \mathrm{RuO}_{4}, \mathrm{Ru}(\mathrm{OH})_{3}, \mathrm{Ru}(\mathrm{OH})_{4}$, $\mathrm{RuCl}_{3}$, and $\mathrm{RuS}_{2}$. The relative stability of the discrete solids in oxidizing conditions $\left(\mathrm{pO}_{2(\mathrm{~g})}=0.68 \mathrm{~atm}\right)$ is given in Figure 22 . The selected thermodynamic data are reported in Table 12. The solids in increasing order of stability for the conditions outlined in Figure 22 are: $\mathrm{Ru}(\mathrm{OH})_{3}, \mathrm{RuO}_{4}$, $\mathrm{Ru}(\mathrm{OH})_{4}$, and $\mathrm{RuO}_{2}$ (amorphous, hydrated). $\mathrm{RuCl}_{3}$ and $\mathrm{RuS}_{2}$ do not appear in Figure 22 because they are too soluble and fall beyond the boundaries of the figure. From Figure 22 it can be ascertained that $\mathrm{RuO}_{2}$ (amorphous, hydrated) would be most stable over the $\mathrm{pH}$ range and up to reducing environments equivalent to $\mathrm{pO}_{2}$ of 50 . In extremely reducing conditions $\left(\mathrm{pO}_{2}=80\right)$ where $\mathrm{H}_{2} \mathrm{~S}(\mathrm{aq})$ would be the most stable sulfur species, $\mathrm{RuS}_{2}$ would maintain lower activities than $\mathrm{RuO}_{2}$ and hence would be the most stable.

The activity of various solution complexes of ruthenium in equilibrium with $\mathrm{RuO}_{2}$ (amorphous, hydrated) in oxidizing $\left(\mathrm{pO}_{2}, 0.68\right)$ and other conditions spelled out in the graph are given in Figure 23. The thermodynamic data used to construct Figure 23 were selected from several sources and are reported in Table 12. Baes and Mesmer (1976) indicate that the thermodynamic data on ruthenium complexes are either not available or are not very accurate. However, it was decided to construct Figure 23 using the existing data to estimate the nature of the species that may be present in solution.

Figure 23 indicates that in an oxidizing environment, significant activity of uncomplexed $\mathrm{Ru}^{4+}$ will be present only in very acidic conditions $(\mathrm{pH}<2)$. Some of the ruthenium species which may be present in solution are $\mathrm{RuO}_{4}{ }^{-}, \mathrm{RuO}_{4}{ }^{2-}, \mathrm{RuO}_{4}, \mathrm{Ru}(\mathrm{OH})_{2}{ }^{2+}, \mathrm{RuO}_{4}(\mathrm{OH})^{-}, \mathrm{RuCl}_{5}(\mathrm{OH})^{2-}, \mathrm{Ru}^{4+}$, and $\mathrm{Ru}^{3+}$. Among these species, $\mathrm{Ru}^{4+}$ would be predominant in $\mathrm{pH}<2, \mathrm{Ru}(\mathrm{OH})_{2}{ }^{2+}$ in $\mathrm{pH} 2$ to 5.2 , $\mathrm{RuO}_{4}{ }^{-}$in $\mathrm{pH} 5.2$ to 10.5 , and $\mathrm{RuO}_{4}{ }^{2-}$ in $\mathrm{pH}>10.5$. With an increase in reducing conditions, the activity of $\mathrm{Ru}^{3+}$ would increase, the activity of $\mathrm{RuO}_{4}{ }^{\circ}, \mathrm{RuO}_{4}{ }^{2-}$ and $\mathrm{RuO}_{4} \mathrm{OH}^{-}$would decrease and the rest of the species would remain unchanged in activity. The nature of the predominant solution species is highly dependent upon the oxidation-reduction conditions, as is 
the most stable solid compound. The predominant ruthenium species are cationic below pH 5 and anionic above pH 5. Hence, ion exchange on soils and rocks, mainly cation exchange, would be of importance only below pH 5 under these conditions. 


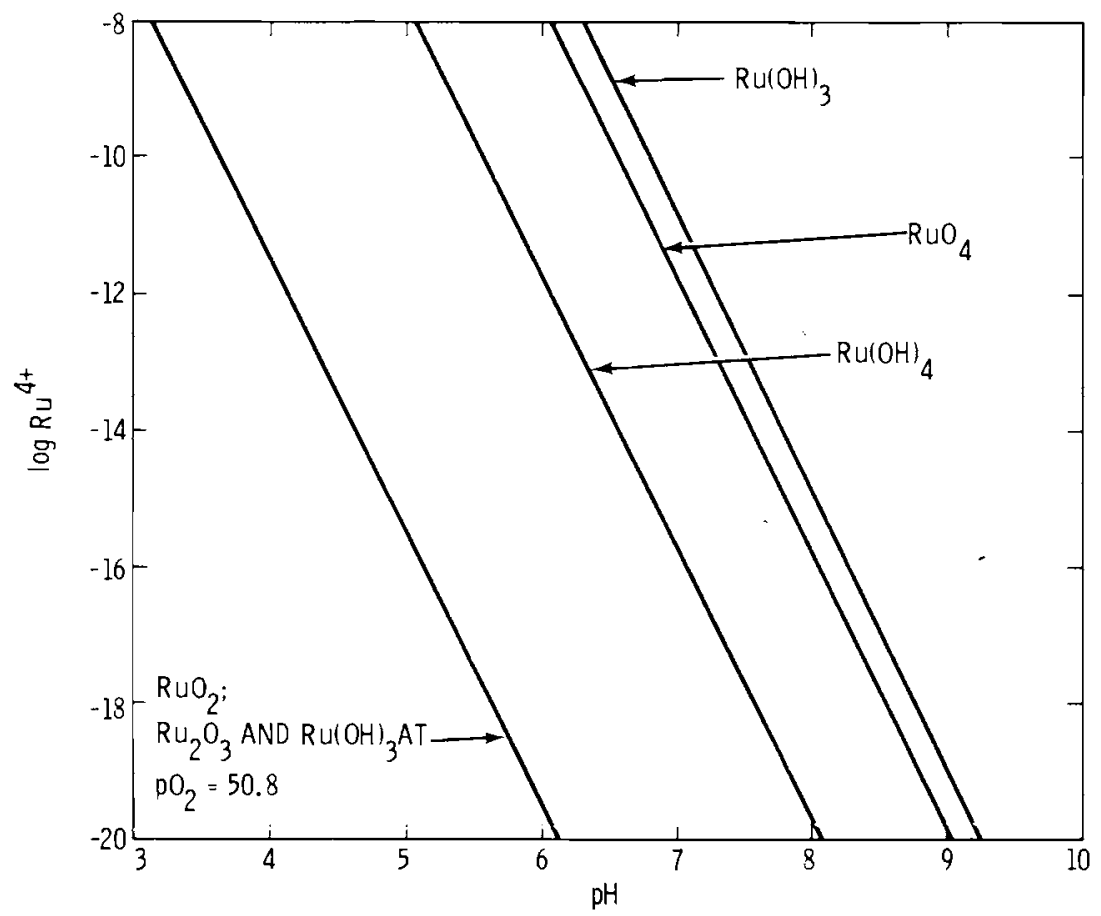

FIGURE 22. The Relative Stability of Various Ruthenium Solids in an Oxidizing Soil Environment $\left[\mathrm{pO}_{2}(\mathrm{~g})=\right.$ $0.68 \mathrm{~atm}], \mathrm{pC}^{-}=\mathrm{pSO}_{4}{ }^{2-}=2.5$ 
TABLE 12. Selected Equilibrium Constants (K) at $25^{\circ} \mathrm{C}$ and One Atmosphere Pressure for Reactions Involving Ruthenium

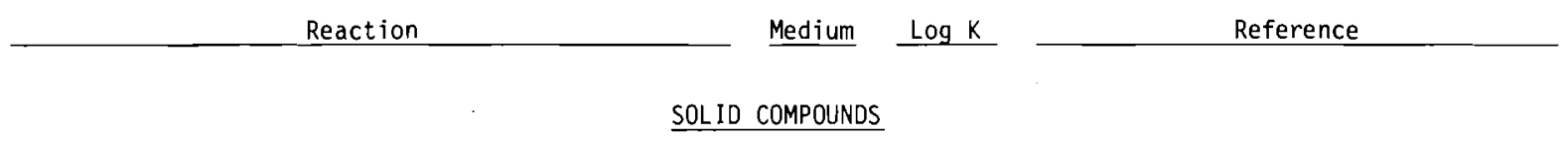

$$
\begin{aligned}
& \mathrm{RuO}_{2} \text { (amorphous hydrated) }+4 \mathrm{H}^{+} \rightleftarrows \mathrm{Ru}^{4+}+2 \mathrm{H}_{2} \mathrm{O} \\
& \mathrm{RuO}_{4}+4 \mathrm{H}^{+} \\
& \rightleftarrows \mathrm{Ru}^{4+}+2 \mathrm{H}_{2} \mathrm{O}+\mathrm{O}_{2} \quad 0 \quad 15.43 \\
& \mathrm{Ru}(\mathrm{OH})_{3}+3 \mathrm{H}^{+} \\
& \mathrm{Ru}(\mathrm{OH})_{4}+4 \mathrm{H}^{+} \\
& \rightleftarrows \mathrm{Ru}^{3}+3 \mathrm{H}_{2} \mathrm{O} \\
& 7.8 \text { Sillen and Martell (1964) } \\
& \rightleftarrows \mathrm{Ru}^{4+}+4 \mathrm{H}_{2} \mathrm{O} \quad 0 \quad 12.30 \\
& \mathrm{RuCl}_{3} \\
& \mathrm{RuS}_{2}+40_{2} \\
& \rightarrow \mathrm{Ru}^{3+}+3 \mathrm{Cl}^{-} \\
& \text {4.96 Trotman-Dickinson (1973) } \\
& \rightleftarrows \mathrm{Ru}^{4+}+2 \mathrm{SO}_{4}^{2-} \\
& \text { a. } \quad 187.62
\end{aligned}
$$

\begin{tabular}{|c|c|c|}
\hline$\stackrel{\mathrm{RuO}_{4}^{2-}}{2-}$ & 0 & 10.19 \\
\hline$\mp \mathrm{RuO}_{4}^{-}$ & 0 & 17.23 \\
\hline$\neq \mathrm{Ru}^{3+}$ & 0 & 11.35 \\
\hline$\rightleftarrows \mathrm{Ru}^{4+}+2 \mathrm{O}_{2}+5 \mathrm{e}^{-}$ & 0 & -84.04 \\
\hline
\end{tabular}

\section{OXIDATION-REDUCTION REACTIONS}

$$
\begin{aligned}
& \mathrm{RuO}_{4}^{-}+e^{-} \\
& \mathrm{RuO}_{4}^{\circ}+e^{-} \\
& \mathrm{Ru}^{4+}+e^{-} \\
& \mathrm{RuO}_{4}^{-}
\end{aligned}
$$

\section{OTHER REACTIONS}

$$
\begin{aligned}
& \mathrm{RuO}_{4}{ }^{\circ}+\mathrm{H}_{2} \mathrm{O} \\
& \mathrm{Ru}^{4+}+2 \mathrm{H}_{2} \mathrm{O} \\
& \mathrm{Ru}^{4+}+5 \mathrm{Cl}^{-}+\mathrm{H}_{2} \mathrm{O}
\end{aligned}
$$

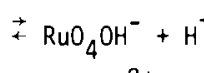

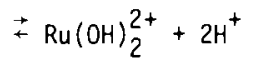$$
0
$$$$
0
$$$$
-11
$$

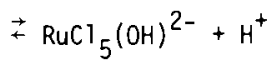

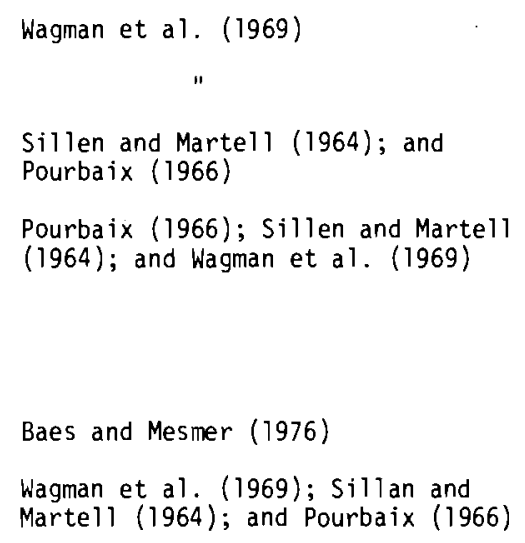

Baes and Mesmer (1976)

Wagman et al. (1969); Sillan and Martell (1964); and Pourbaix (1966)

8.13 


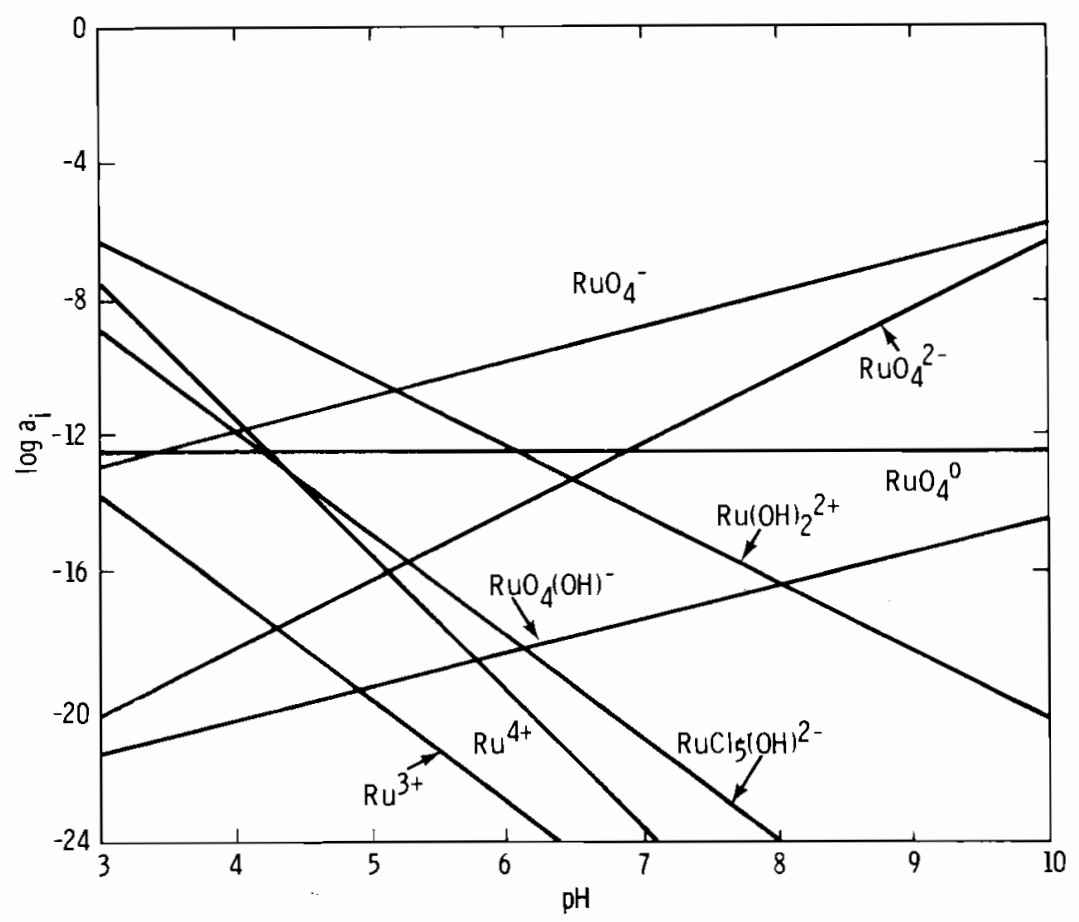

FIGURE 23. The Activity of Various Ruthenium Species in Equilibrium with $\mathrm{RuO}_{2}$ (Amorphous Hydrate) in an Oxidizing Soil Environment $\left[\mathrm{pO}_{2}(\mathrm{~g})=\right.$ $0.68 \mathrm{~atm}], \mathrm{pCl}^{-}=2.5$ 


\section{PREDICTED VS. OBSERVED BEHAVIOR OF RUTHENIUM}

Most of the thermodynamic data for the ruthenium complexes with common solution ions of sulfate, nitrate, carbonate, chloride, and organic ligands do not exist. Thus an estimation of their relative importance in waste disposal operations or spills is difficult, requiring experimental studies for evaluation in each case. Based upon data of other species (Figure 23), it can be stated that the adsorption of anionic species that predominate above a $\mathrm{pH}$ of approximately 5 would be minimal.

Adsorption of $\mathrm{Ru}^{3+}$ peaks at $\mathrm{pH} 6.6$ and 14, with a definite correlation between $\mathrm{pH}$ and ruthenium Kd for all ruthenium species (Rhodes, 1957; Eichholz et al., 1967; Amy, 1971). Adsorption of all ruthenium species is low at low $\mathrm{pH}$, and little if any adsorption of anionic species occurs at any $\mathrm{pH}$ (Spitsyn et a1., 1958; Haney et a1., 1962; Brown and Haney, 1964; Raymond, 1964, 1965; Brown, 1967; Magno et a1., 1970; Schu1z, 1965). Some instances of migration on suspended solids have been noted (Champlin and Eichholz, 1976; Eichholz et a1., 1967). Hydrated ferric oxide is a good adsorbent for ruthenium (Kepak, 1966). Low ruthenium Kd values have been reported in high salt solutions (Anonymous, 1973), probably as a result of nitrate complexing. Migration of most ruthenium complexes through the soil column is relatively rapid (Pickering et al., 1966; Izrael and Rovinskii, 1970; Amy, 1971). 


\section{STRONTIUM}

Strontium is an alkaline earth and forms several salts. Thermodynamic data for various strontium compounds $\left[\mathrm{SrO}, \mathrm{Sr}(\mathrm{OH})_{2}, \mathrm{SrF}_{2}, \mathrm{SrCl}_{2}, \mathrm{SrCl}_{2} \cdot 2 \mathrm{H}_{2} \mathrm{O}\right.$, $\cdot \mathrm{SrCl}_{2} \cdot 3 \mathrm{H}_{2} \mathrm{O}, \mathrm{SrCl}_{2} \cdot \mathrm{H}_{2} \mathrm{O}, \mathrm{SrHPO}_{4}, \mathrm{Sr}_{3}\left(\mathrm{PO}_{4}\right)_{2}, \mathrm{SrSO}_{4}, \mathrm{Sr}\left(\mathrm{NO}_{3}\right)_{2}, \mathrm{SrCO}_{3}, \mathrm{SrSiO}_{3}$, $\mathrm{SrSiO}_{4}$ ] were considered in order to determine their stability (Table 13). Except for $\mathrm{SrSiO}_{3}, \mathrm{SrHPO}_{4}, \mathrm{Sr}_{3}\left(\mathrm{PO}_{4}\right)_{2}, \mathrm{SrCO}_{3}$, and $\mathrm{SrSO}_{4}$, the strontium solid phases are too soluble to show in Figure 24 . In an acidic environment, most of the strontium solids will be highly soluble, and if the activity of $\mathrm{Sr}^{2+}$ in solution exceeds $10^{-4}$ moles/lititer, $\mathrm{SrSO}_{4}$ can precipitate and would be a stable phase. However, in alkaline conditions, $\mathrm{SrCO}_{3}$ would be the stable phase and the compound that may maintain strontium activity in soil solutions.

The activity of various solution species in equilibrium with $\mathrm{SrCO}_{3}$ and at anionic activities of $\mathrm{pCl}^{-}=\mathrm{pSO}_{4}{ }^{2-}=2.5, \mathrm{pNO}_{3}{ }^{-}=3.0, \mathrm{pF}^{-}=4.5, \mathrm{pH}_{2} \mathrm{PO}_{4}^{-}$ $=5$ and $\mathrm{pCO}_{2(\mathrm{~g})}=1.52 \mathrm{~atm}$ are plotted in Figure 25. Although strontium forms complexes with the various anions listed above (Table 13), the solution complexes do not contribute significantly to the total strontium activity in solution. $\mathrm{Sr}^{2+}$ would be the dominant solution species over the environmental $\mathrm{pH}$ range of interest and would be expected to be adsorbed via an ion exchange reaction. 
TABLE 13. Selected Equilibrium Constants (K) at $25^{\circ} \mathrm{C}$ and One Atmosphere Pressure for Reactions Involving Strontium

\begin{tabular}{|c|c|c|c|c|}
\hline \multicolumn{2}{|c|}{ Reaction } & Medium $(a)$ & \multirow[t]{2}{*}{$\underline{\log K}$} & Reference \\
\hline \multicolumn{4}{|c|}{ Solid Compounds } & \\
\hline $\mathrm{SrCO}_{3}$ & $\rightleftarrows \mathrm{Sr}^{2+}+\mathrm{CO}_{3}^{2-}$ & 0 & -9.25 & $\begin{array}{l}\text { Parker et al. (1971); } \\
\text { Wagman et a } 1 .(1968)\end{array}$ \\
\hline $3 \mathrm{rHF}_{4}$ & $\vec{s} \mathrm{sr}^{2+}+\mathrm{r}^{r}+\mathrm{PO}_{4}^{3-}$ & u & -19.35 & $"$ \\
\hline $\mathrm{Sr}_{3}\left(\mathrm{PO}_{4}\right)_{2}$ & $\overrightarrow{+} 3 \mathrm{Sr}^{2+}+2 \mathrm{PO}_{4}^{3-}$ & 0 & -27.8 & Sillen and Martell (1964) \\
\hline $\mathrm{SrO}+2 \mathrm{H}^{+}$ & $\stackrel{+}{+} \mathrm{Sr}^{2}+\mathrm{H}_{2} \mathrm{O}$ & 0 & 41.13 & Parker et al. (1971) \\
\hline $\mathrm{SrSO}_{4}$ & $\rightarrow \mathrm{Sr}^{2+}+\mathrm{SO}_{4}^{2-}$ & 0 & -6.47 & $\begin{array}{l}\text { Parker et al. (1971); } \\
\text { Wagman et al. (1968) }\end{array}$ \\
\hline $\mathrm{SrSiO}_{3}+\mathrm{H}_{2} \mathrm{O}+2 \mathrm{H}^{+}$ & $\overrightarrow{+} \mathrm{Sr}^{2+}+\mathrm{H}_{4} \mathrm{SiO}_{4}$ & 0 & 14.07 & $\begin{array}{l}\text { Parker et al. (1971); } \\
\text { Helgeson (1969) }\end{array}$ \\
\hline $\mathrm{SrSiO}_{4}+4 \mathrm{H}^{+}+2 \overline{\mathrm{e}}$ & $\because \mathrm{Sr}^{2+}+\mathrm{H}_{4} \mathrm{SiO}_{4}$ & 0 & -56.76 & $\begin{array}{l}\text { Parker et al. (1971); } \\
\text { Wagman et al. (1968); }\end{array}$ \\
\hline
\end{tabular}

Hydrolysis and Oiher Reactions

\begin{tabular}{|c|c|c|c|c|}
\hline $\mathrm{Sr}^{2+}+\mathrm{OH}^{-}$ & $\vec{\leftarrow} \mathrm{SrOH}^{+}$ & 0 & 0.81 & Parker et a1. (1971) \\
\hline $\mathrm{Sr}^{2+}+2 \mathrm{H}_{2} \mathrm{O}$ & $\stackrel{\mathrm{Sr}}{\mathrm{OOH})_{2}}{ }^{\circ}+2 \mathrm{H}^{+}$ & 0 & -28.51 & $\begin{array}{l}\text { Wagman et al. (1968); } \\
\text { Parker et al. }(1971)\end{array}$ \\
\hline $\mathrm{Sr}^{2+}+2 \mathrm{Cl}^{-}$ & $\vec{\leftarrow} \mathrm{SrCl}_{2}{ }^{\circ}$ & 0 & 0.00 & Parker et al. (1971) \\
\hline $\mathrm{Sr}^{2+}+2 \mathrm{~F}^{-}$ & $\stackrel{\mathrm{SrF}_{2}}{\circ}$ & 0 & 2.02 & Chase et al. (1975) \\
\hline $\mathrm{Sr}^{2+}+\mathrm{NO}_{3}^{-}$ & $\stackrel{\mathrm{SrNO}_{3}}{+}$ & 0 & 0.82 & Sillen and Martell (1964) \\
\hline $\mathrm{Sr}^{2+}+2 \mathrm{NO}_{3}^{-}$ & $\rightleftarrows \mathrm{Sr}\left(\mathrm{NO}_{3}\right)_{2}^{\circ}$ & 0 & 0.00 & Parker et al. (1971) \\
\hline $\mathrm{Sr}^{2+}+\mathrm{SO}_{4}^{2-}$ & $\stackrel{\mathrm{SrSO}_{4}}{\circ}$ & 0 & 0.00 & $"$ \\
\hline $\mathrm{Sr}^{2+}+\mathrm{PO}_{4}^{3-}$ & $\overrightarrow{\mathrm{SrPO}_{4}^{-}}$ & $0.15(\mathrm{NaCl})$ & 4.18 & Sillen and Martell (1964) \\
\hline
\end{tabular}

(a) The nature of the medium to which the equilibrium constants refer, for example, 0 - zero ionic strength, var - ionic medium varied, $2\left(\mathrm{HClO}_{4}\right)$ - ionic strength held constant at the value stated (2 moles/lliter) by the addition of the chemical shown in parentheses, 1.0 $\mathrm{HClO}_{4}$ - constant concentration of the substance stated $\left(1.0\right.$ moles/lliter $\left.\mathrm{HClO}_{4}\right)$. 


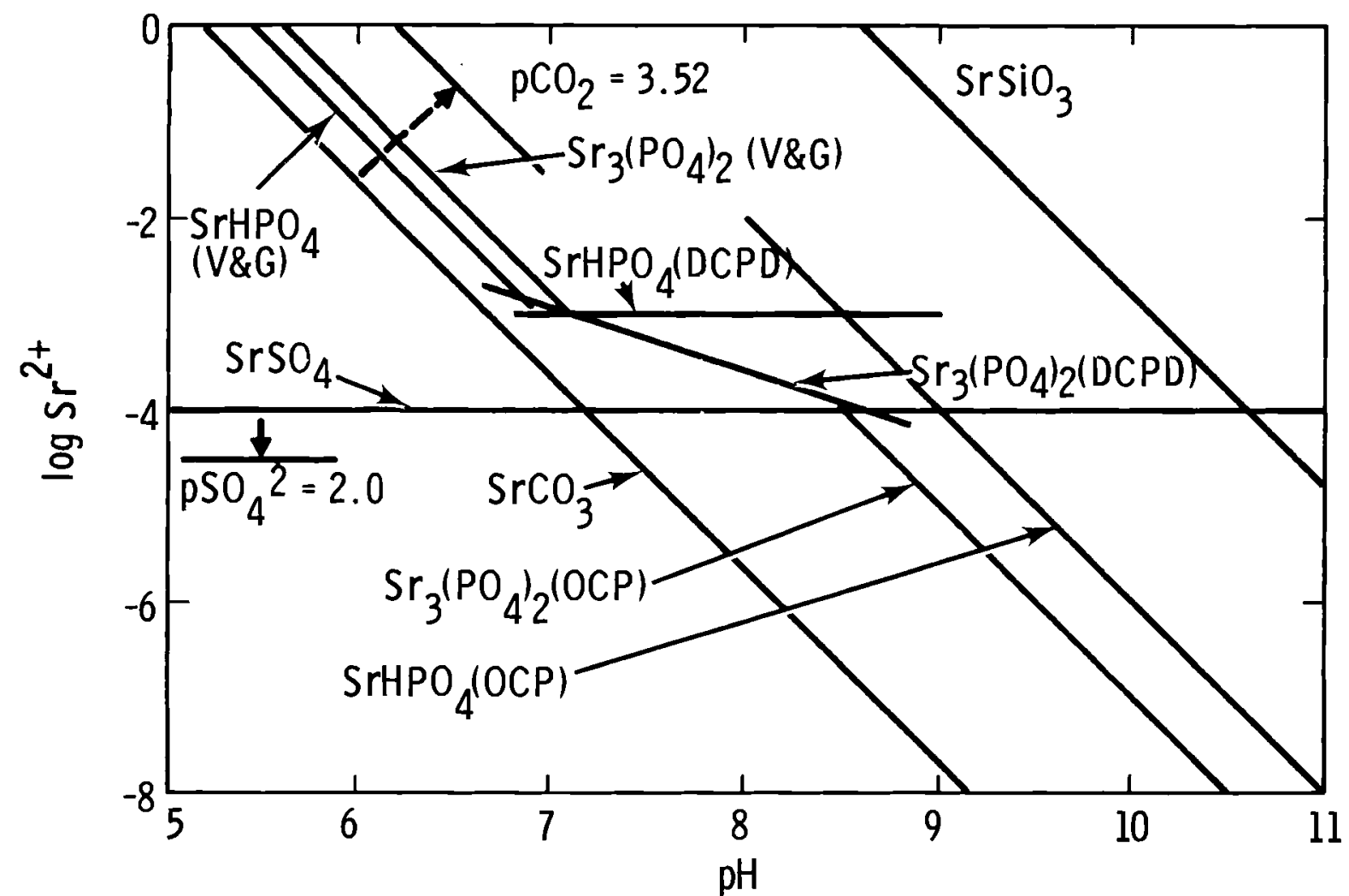

FIGURE 24. The Relative Stability of Strontium Solids at $\mathrm{pCa}^{2+}=\mathrm{pSO}_{4}^{2-}=2.5$, $\mathrm{pH}_{4} \mathrm{SiO}_{4}=3.1, \mathrm{pCO}_{2}=1.52$ and Phosphate Levels in Equilibrium with Variscite and Gibbsite ( $V$ and $G$ ), Dicalcium Phosphate Dihydrate (DCPD), and Octacalcium Phosphate (OCP) 


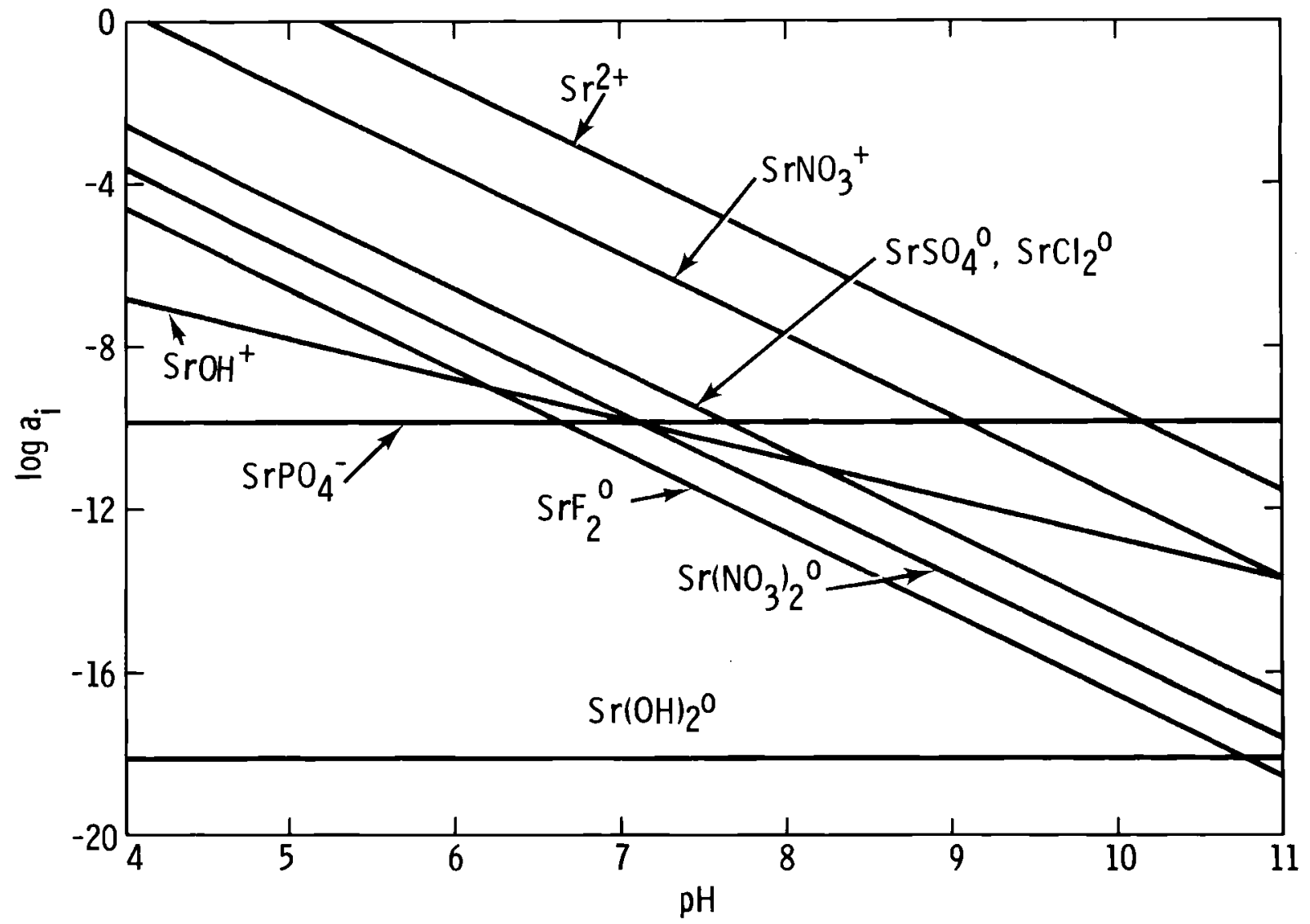

FIGURE 25. The Activities of Various Strontium Species in Equilibrium with $\operatorname{SrCO}_{3}(\mathrm{~s})$ in the Soil at $\mathrm{pCl}^{-}=\mathrm{pSO}_{4}^{-}=2.5, \mathrm{pNO}_{3}^{-}=3.0, \mathrm{pF}^{-}=4.5$, $\mathrm{pCO}_{2}=1.52$ and $\mathrm{pH}_{2} \mathrm{PO}_{4}^{-}=5.0$ 
PREDICTED VS. OBSERVED BEHAVIOR OF STRONTIUM

Most of the strontium chemical compounds for which data are available are very soluble (Figure 24). Only in highly alkaline soils could $\mathrm{SrCO}_{3}$ control strontium activity in solutions. Strontium in solution is expected to be predominantly present as $\mathrm{Sr}^{2+}$ (Figure 25) and to be exchangeable on soils. Laboratory studies show that ion exchange is the principal mechanism of strontium adsorption by soils and rocks (McHenry, 1955, 1958; Rhodes and Nelson, 1957; Klechovsky et a1., 1958; Prout, 1958, 1959; Baker and Beetem, 1961). Strontium Kd values are usually directly correlated with cation exchange capacity of the soil or rock, but not invariably (McHenry, 1958). A direct correlation between solution $\mathrm{pH}$ and strontium $\mathrm{Kd}$ has also been reported (Rhodes, 1957; Prout, 1958, 1959; Baetsle et a1., 1964; Juo and Barber, 1970), which suggests hydrogen ion competition with $\mathrm{Sr}^{2+}$ for exchange sites. Strontium Kd values fall rapidly from 100 to $200 \mathrm{ml} / \mathrm{g}$ or more in low ionic strength salt solutions to less than $5 \mathrm{ml} / \mathrm{g}$ in high ionic strength salt solutions (Rhodes, 1957). Strontium and calcium most readily replace trace strontium (Kokotov et a1., 1961, 1962; Schulz, 1965) and cause strontium radioisotopes to migrate rapidly when present in groundwater with the strontium (Spitsyn et a1., 1960). Low pH also results in a relatively high strontium migration velocity in groundwater (Parsons, 1963; Baetsle et a1., 1964) with the strontium and groundwater velocity identical at pH 3. Calcium competition is the probable cause of the $90 \%$ soluble strontium migration from the lagoons of the Nuclear Fuel Services plant (Magno et a1., 1970), although strontium also migrates on soil particulates (Carlile and Hajek, 1967). The many strontium Kd values determined by Berak (1963) demonstrated that secondary minerals such as clays and zeolites are much better strontium adsorbers and are more selective for strontium from solutions containing strontium and calcium than are the primary minerals such are quartz, feldspars and pyroxenes. Another mechanism for strontium removal from solution is its coprecipitation with calcite (Jenne and Wahlberg, 1968; Varga and Jacobs, 1970) or adsorption during phosphate or oxalate replacement of carbonate in calcite (McHenry, 1958; Ames, 1958). Strontium organic complexes are known that result in a strontium fixation (Mortensen and Marcusiu, 1963) or enhanced migration rates (Himes and Shufeldt, 1970). 


\section{TECHNET IUM}

Baes and Mesmer (1976) reported that technetium (VII) forms strong peracids $\left(\mathrm{HMO}_{4}\right)$, and that its oxides are very soluble. No information is available concerning the soluble complexes of technetium or the solubility of its salts (Pourbaix, 1966). Pertechnetate ion, $\mathrm{TCO}_{4}^{-}$, is the most stable species of the element in aqueous solutions (Boyd, 1959). 
PREDICTED VS. OBSERVED BEHAVIOR OF TECHNETIUM

Pertechnetate ion, $\mathrm{TcO}_{4}^{-}$, is the most stable species of technetium in aqueous solutions (Boyd, 1959). A major portion of the ion exchange capacity of soils and sediments exhibit cation exchange capacity at the usual near-neutral pH conditions. Therefore a negatively charged $\mathrm{TCO}_{4}^{-}$would hardly be exchanged, and hence show little adsorption by soils and rocks (Routson et a1., 1976, 1977). Gast (1975) reported high Kd values (800 to 900) for soils with high organic matter. He also reported the presence of $\mathrm{H}_{2} \mathrm{~S}$ in his equilibrating samples, and suggested that the high Kd values were due to precipitation of technetium as $\mathrm{Tc}_{2} \mathrm{~S}_{7}$ in the presence of $\mathrm{H}_{2} \mathrm{~S}$ (Kotegov, 1968). In conditions where the soil contains appreciable organic matter, the Tc(VII) may be reduced to Tc(IV) and adsorbed (Wildung et al., 1975). Tc(IV) can coprecipitate with ferric hydroxide (Anders, 1960). With the exception of some sedimentary rocks, most rocks contain very little organic matter. Hence, technetium Kd values of close to zero would normally be encountered in oxidizing conditions and in rocks and soils that are relatively low in organic matter. More study is required to determine the nature of the organic matter-pertechnetate ion reaction, and the influence of redox conditions on adsorption of technetium by soils and rocks. 


\section{THORIUM}

Figure 26 relates the activity of $\mathrm{Th}^{4+}$ to $\mathrm{pH}$ under an assumed weathering environment in equilibrium with various thorium solid phases. The thermodynamic data for various compounds are reported in Table 14 . Under the assumptions outlined in Figure 26, all thorium compounds except $\mathrm{ThF}_{4}$ can be arranged in an increasing order of stability throughout the $\mathrm{pH}$ range as follows: $\mathrm{Th}\left(\mathrm{HPO}_{4}\right)_{2}, \mathrm{Th}_{3}\left(\mathrm{PO}_{4}\right)_{4}, \mathrm{Th}(\mathrm{OH})_{4}$, and $\mathrm{ThO}_{2} . \mathrm{ThF}_{4}$ would be least stable in a $\mathrm{pH}$ of approximately $>7$ and most stable approximately in $\mathrm{pH}<4$.

The relative activity of solution species of thorium in equilibrium with $\mathrm{ThO}_{2}$ (s) at assumed activities of various ions is plotted in Figure 27. The thermodynamic data for various solution species is reported in Table 14. In general, the total concentration of thorium in solution decreases with an increase of $\mathrm{pH}$ from zero to 5 . Above 5, pH does not affect thorium concentration in solution due to the formation of $\mathrm{Th}(\mathrm{OH})_{4}^{\circ}$. The activity of all positively charges species decreases with an increase in $\mathrm{pH}$, while the activity of the negatively charges species increases with the increase in $\mathrm{pH}$. Under the conditions assumed for Figure 27, the total activity of thorium in solution would be expected to be approximately $10^{-9.6}$ moles/liter above $\mathrm{pH} 5$.

In addition to $\mathrm{OH}^{-}$, thorium forms various complexes with $\mathrm{SO}_{4}{ }^{2-}, \mathrm{PO}_{4}^{3-}$, $\mathrm{Cl}^{-}$, $\mathrm{NO}_{3}{ }^{-}$, and $\mathrm{F}^{-}$. Various anions in increasing order of their importance to forming complexes are: $\mathrm{NO}_{3}{ }^{-}, \mathrm{Cl}^{-}, \mathrm{H}_{2} \mathrm{PO}_{4}{ }^{-}, \mathrm{SO}_{4}{ }^{2-}$, and $\mathrm{F}^{-}$. Figure 27 shows that thorium exists as $\mathrm{Th}^{4+}$ only in very acidic solutions $(\mathrm{pH}<3)$. Above $\mathrm{pH} 3, \mathrm{Th}^{4+}$ hydrolyzes very rapidly and it does not contribute significantly to the total thorium concentration. Under the conditions assumed for Figure $27, \mathrm{ThF}^{3+}$ would be a dominant solution species at $\mathrm{pH}<5$, and $\mathrm{Th}(\mathrm{OH})_{4}$ would be a dominant solution species at $\mathrm{pH}>5$. If fluoride ion is absent from the solution, or its concentration is extremely $1 \mathrm{OW}, \mathrm{Th}(\mathrm{OH})_{2}{ }^{2+}$ would mainly control the thorium concentration in solution at $\mathrm{pH}<5$. 


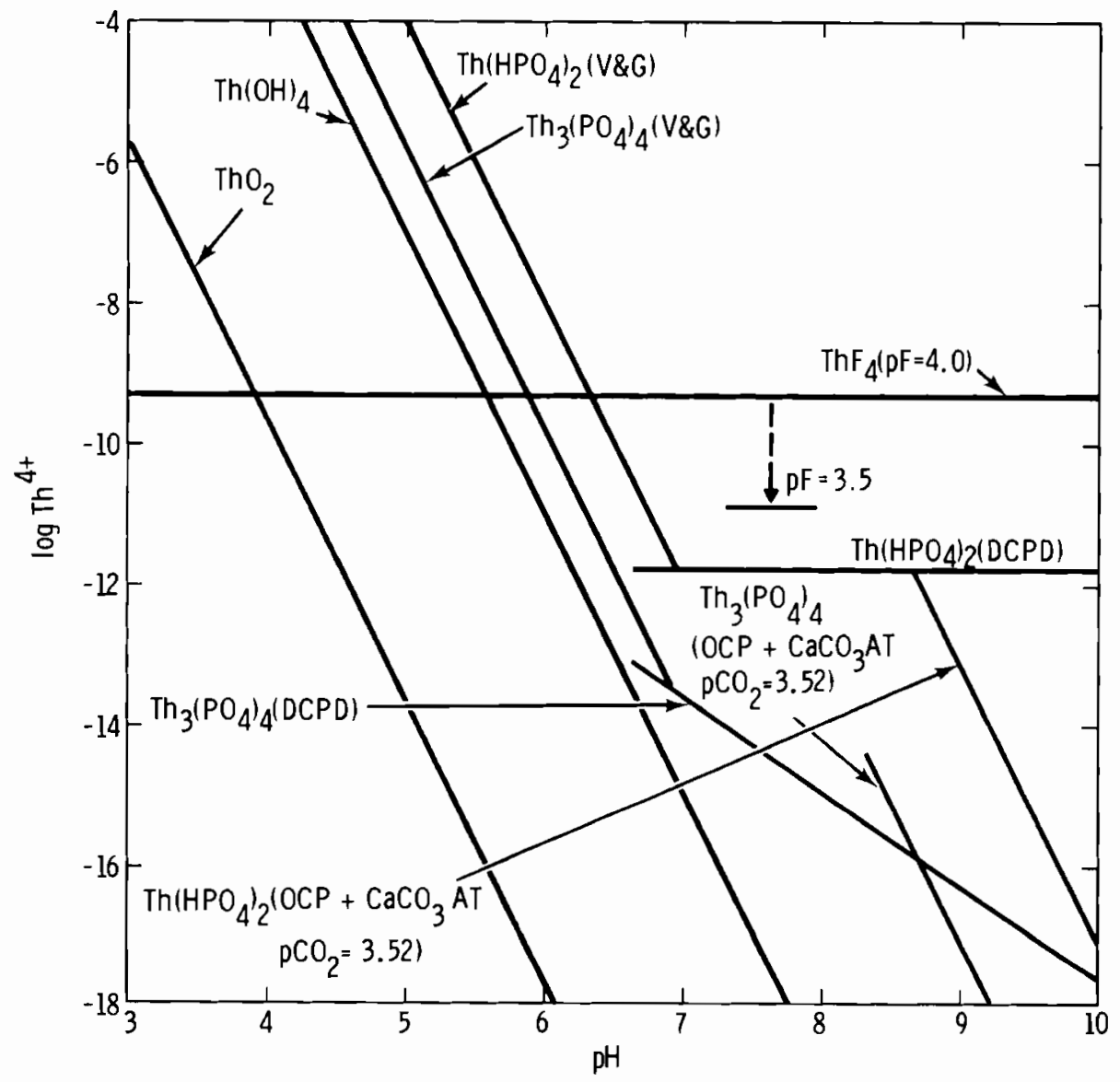

FIGURE 26. The Relative Stability of Various Thorium Solids in Equilibrium with Variscite and Gibbsite ( $V$ and $G$ ), Dicalcium Phosphate Dihydrate (DCPD) 


\section{TABLE 14. Selected Equilibrium Constants (K) at $25^{\circ} \mathrm{C}$ and One Atmo- sphere Pressure for Various Reactions Involving Thorium}

\begin{tabular}{|c|c|c|c|c|}
\hline \multicolumn{2}{|c|}{ Reaction } & \multirow{2}{*}{$\begin{array}{l}\text { Medium }^{(a)} \\
\text { Solid Compoun } \\
\text { Sold }\end{array}$} & \multirow[t]{2}{*}{$\log K$} & \multirow[t]{2}{*}{ Reference } \\
\hline & & & & \\
\hline $\mathrm{ThF}_{4}$ & $\stackrel{+}{\mathrm{Th}^{4+}}+4 \mathrm{OH}^{-}$ & Var & -25.3 & Sillen and Martell (1964) \\
\hline $\mathrm{Th}(\mathrm{OH})_{4}$ & 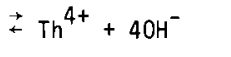 & 0 & -43.17 & $"$ \\
\hline $\mathrm{ThO}_{2}+4 \mathrm{H}^{+}$ & $\overrightarrow{\mathrm{Th}^{4+}}+2 \mathrm{H}_{2} \mathrm{O}$ & 0 & 6.3 & Baes and Mesmer (1976) \\
\hline $\mathrm{Th}\left(\mathrm{HPO}_{4}\right)_{2}$ & 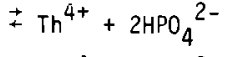 & $\operatorname{Var}$ at $20^{\circ} \mathrm{C}$ & -19.92 & Sillen and Martell (1964) \\
\hline $\mathrm{Th}_{3}\left(\mathrm{PO}_{4}\right)_{4}$ & $\pm 3 \mathrm{Th}^{4+}+4 \mathrm{PO}_{4}^{3-}$ & Var at $20^{\circ} \mathrm{C}$ & -78.59 & $"$ \\
\hline \multicolumn{5}{|c|}{ Oxidation-Reduction Reactions } \\
\hline $\mathrm{Th}^{4+}-\mathrm{e}^{-}$ & $\pm \mathrm{Th}^{3+}$ & 0 & -59.17 & Keller (1971) \\
\hline $\mathrm{Th}^{4+}+4 \mathrm{e}^{-}$ & $\rightleftarrows \mathrm{Th}(\mathrm{s})$ & 0 & -128.40 & Sillen and Martell (1964) \\
\hline
\end{tabular}

Hydrolysis Reactions

$\begin{array}{lllrl}\mathrm{Th}^{4+}+\mathrm{H}_{2} \mathrm{O} & \rightleftarrows \mathrm{ThOH}^{3+}+\mathrm{H}^{+} & 0 & -3.20 & \text { Baes and Mesmer (1976) } \\ \mathrm{Th}^{4+}+2 \mathrm{H}_{2} \mathrm{O} & \rightleftarrows \mathrm{Th}(\mathrm{OH})_{2}^{2+}+2 \mathrm{H}^{+} & 0 & -6.93 & " \\ \mathrm{Th}^{4+}+3 \mathrm{H}_{2} \mathrm{O} & \rightleftarrows \mathrm{Th}(\mathrm{OH})_{3}^{+}+3 \mathrm{H}^{+} & 0 & <-11.7 & " \\ \mathrm{Th}^{4+}+4 \mathrm{H}_{2} \mathrm{O} & +\mathrm{Th}(\mathrm{OH})_{4}^{0}+4 \mathrm{H}^{+} & 0 & -15.9 & " \\ \mathrm{Th}(\mathrm{OH})_{4}+2 \mathrm{H}^{-} & \rightleftarrows \mathrm{Th}(\mathrm{OH})_{6}^{2-} & 0 & -5.80 & \text { Sillen and Martell (1964) } \\ 2 \mathrm{Th}^{4+}+2 \mathrm{H}_{2} \mathrm{O} & \pm \mathrm{Th}_{2}(\mathrm{OH})_{2}^{6+}+2 \mathrm{H}^{+} & 0 & -6.14 \text { Baes and Mesmer (1976) }\end{array}$

0ther Reactions

\begin{tabular}{|c|c|c|c|c|}
\hline $\mathrm{Th}^{4+}+\mathrm{Cl}^{-}$ & $\pm \mathrm{ThCl}^{3+}$ & 0 & 1.38 & Sillen and Marte1l (1964) \\
\hline $\mathrm{Th}^{4+}+\mathrm{F}^{-}$ & $\pm \mathrm{ThF}^{3+}$ & 0 & 8.65 & $"$ \\
\hline $\mathrm{Th}^{4+}+\mathrm{NO}_{3}^{-}$ & $\vec{\leftarrow} \mathrm{ThNO}_{3}{ }^{3+}$ & $2.0\left(\mathrm{HClO}_{4}\right)$ at $20^{\circ} \mathrm{C}$ & 0.78 & " \\
\hline $\mathrm{ThNO}_{3}{ }^{3+}+\mathrm{NO}_{3}^{-}$ & $\rightleftarrows \mathrm{Th}\left(\mathrm{NO}_{3}\right)_{2}^{2+}$ & $2.0\left(\mathrm{HClO}_{4}\right)$ at $20^{\circ} \mathrm{C}$ & 0.33 & $"$ \\
\hline $\mathrm{Th}^{4+}+\mathrm{H}_{3} \mathrm{PO}_{4}$ & 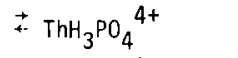 & $2.0\left(\mathrm{NaClO}_{4}\right)$ & 1.89 & $"$ \\
\hline $\mathrm{Th}^{4+}+\mathrm{H}_{3} \mathrm{PO}_{4}$ & $\pm \mathrm{ThH}_{2} \mathrm{PO}_{4}{ }^{3+}+\mathrm{H}^{+}$ & $2.0\left(\mathrm{NaClO}_{4}\right)$ & 2.18 & $"$ \\
\hline $\mathrm{Th}^{4+}+\mathrm{HSO}_{4}^{-}$ & $\pm \mathrm{ThHSO}_{4}{ }^{3+}$ & $1.7\left(\mathrm{NaClO}_{4}\right)$ & 2.3 & $"$ \\
\hline $\mathrm{ThHSO}_{4}{ }^{3+}+\mathrm{HSO}_{4}^{-}$ & $+\mathrm{Th}\left(\mathrm{HSO}_{4}\right)_{2}^{2+}$ & $1.7\left(\mathrm{NaClO}_{4}\right)$ & 1.1 & $"$ \\
\hline $\mathrm{Th}^{4+}+\mathrm{SO}_{4}{ }^{2-}$ & $\stackrel{+}{*} \mathrm{ThSO}_{4}{ }^{2+}$ & $2.0\left(\mathrm{NaClO}_{4}\right)$ & 3.32 & $"$ \\
\hline $\mathrm{ThSO}_{4}{ }^{2+}+\mathrm{SO}_{4}{ }^{2-}$ & $\overrightarrow{\mathrm{Th}}\left(\mathrm{SO}_{4}\right)_{2}{ }^{\circ}$ & $2.0\left(\mathrm{NaClO}_{4}\right)$ & 2.38 & $"$ \\
\hline $\mathrm{Th}\left(\mathrm{SO}_{4}\right)_{2}^{0}+\mathrm{SO}_{4}^{2-}$ & $\rightleftarrows \mathrm{Th}\left(\mathrm{SO}_{4}\right)_{3}^{2-}$ & 0 & 0.76 & $"$ \\
\hline $\operatorname{Th}\left(\mathrm{SO}_{4}\right)_{3}{ }^{2-}+\mathrm{SO}_{4}{ }^{2-}$ & $\pm \mathrm{Th}\left(\mathrm{SO}_{4}\right)_{4}^{4-}$ & 0 & -2.02 & $"$ \\
\hline
\end{tabular}

(a) The nature of the medium to which the equilibrium constants refer, for example, 0 - zero ionic strength, var - ionic medium varied, $2\left(\mathrm{HClO}_{4}\right)$ - ionic strength held constant at the value stated (2 moles/lliter) by the addition of the chemical shown in parentheses, 1.0

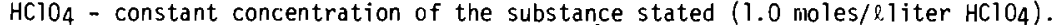




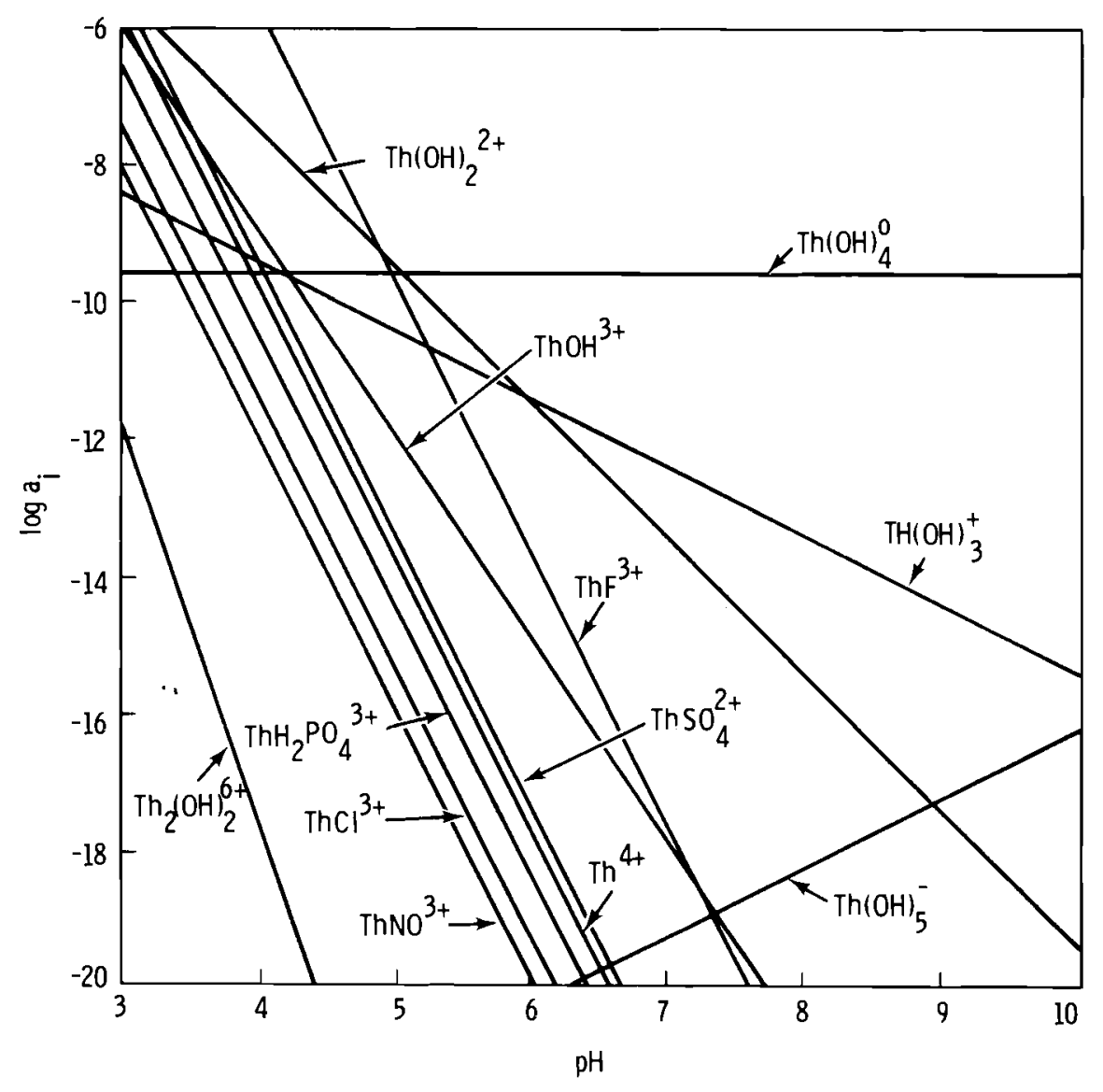

FIGURE 27. Activity of Various Thorium Species in Equilibrium with $\mathrm{ThO}_{2}(\mathrm{~s}), \mathrm{pCl}^{-}=\mathrm{pNO}_{3}^{-}=\mathrm{pSO}_{4}^{2-}=3.0, \mathrm{pF}^{-}=4.5$ and $\mathrm{pH}_{2} \mathrm{PO}_{4}=5.0$ 
PREDICTED VS. OBSERVED BEHAVIOR OF THORIUM

Under alkaline conditions, $\mathrm{Th}(\mathrm{OH})_{4}$ and $\mathrm{ThO}_{2}$ maintain low activities in soil solutions (Figures 26 and 27) and these compounds could form and govern thorium concentration. Thorium hydrolyzes readily even in moderately acidic environments (Figure 27) so that the $\mathrm{Th}^{4+}$ would be present only in very acidic solutions. Laboratory studies also show that thorium tends to precipitate as thorium hydroxide and hydrated thorium oxide in soils (Schu1z, 1965; Rancon, 1973).

An increase in thorium content with increase in $\mathrm{CaCO}_{3}$, phosphate and humus content of soils and sediments has been reported (Kuznetsov et al., 1968; Pashneva et a1., 1965; Menze1, 1968; Yakobenchuck, 1968; Hansen and Huntington, 1969; Pokidin et a1., 1972). However, Tyuryukanova and Kalugina (1971) reported low thorium concentrations in high humus soils (peats and forest podzols) compared with alluvial soils. Thorium adsorption increases with increase in $\mathrm{pH}$ (Rancon, 1973) and decrease in soil particle size (Hansen and Huntington, 1969; Hansen, 1970; Nishiwaki et a1., 1972; Rubtsov, 1966, 1972; Bondietti, 1974). Strong humic and fulvic acid complexes with thorium occur in the neutral to acidic range (Rancon, 1973; Bondietti, 1974) which are noncationic (Desai and Ganguly, 1970) and mobile. It has been reported also that thorium migrates primarily in the colloidal form (polymeric) in the natural environment (Baranov et a1., 1956; Lazarev et a1., 1961; Kimura et a1., 1968). 


\section{TRITIUM}

Tritium $\left(H^{3}\right)$ is a radioactive isotope of hydrogen. Thus, tritium behavior in soils would be expected to be similar to hydrogen and thus could exist as an ion, gas and liquid (tritiated water). Except for the slight differences in vapor pressure, tritiated water behaves the same as ordinary water (Jacobs, 1968). Although no discrete solid phases of tritium are expected in soils, it could associate itself with soil organic compounds containing hydrogen or with some soil minerals as mobile water, water of hydration, or as part of structural hydroxyl groups (Jacobs, 1968; Stewart, 1967).

Tritium rapidly travels at about the same velocity as the soil water or groundwater in the form of HTO. Some replacement of nontritiated water on clays and other hydrated soil constituents occurs, but the reaction is of marginal value as far as tritium retention is concerned. Tritium can move in a vapor phase through the soil under certain conditions as well. 
PREDICTED VS. OBSERVED BEHAVIOR OF TRITIUM

Tritium substitutes readily for the hydrogen in water and thus becomes a part of the hydrological cycle (Jacobs, 1968). Migration of tritium through the groundwater takes place at the same velocity as the groundwater through sandy soils (Haney, 1963, 1964; Haney et a1., 1962; Brown and Haney, 1964; Brown, 1967). Some investigators have reported the selective fixation of tritiated water on clays and other hydrated minerals (Rosenqvist, 1963; Koranda, 1965; Clayton et a1., 1966; Savin, 1967; Stewart, 1967; Rabinowitz, 1969; Rabinowitz et a1., 1973) while other investigators have considered tritium fixation to be minimal (Higgins, 1959; Halevy, 1964; Corey and Horton, 1968; Teller et a1., 1968). However, all of the field studies have indicated that tritium movement is synonomous with water movement (Brown, 1967). 


\section{URANIUM}

The thermodynamic data for different uranium compounds are reported in Table 15. The relative stability of several uranium solid phases, in terms of the uranyl ion activity produced by each, is shown in Figure 28 . Since a11 the compounds shown in Figure 28 are of U(VI), and are plotted as a function of $\mathrm{UO}_{2}{ }^{2+}$, their curves would not move with changes in oxidationreduction conditions. U(IV) compounds, such as $\mathrm{UO}_{2}$, are very soluble in an oxidizing environment and fall outside the boundary of Figure 28 . With an increase in reducing conditions, U(IV) compounds would become more stable. At a $\mathrm{pO}_{2}$ of $>71$, the $\mathrm{UO}_{2}$ curve would fall just below the $\mathrm{UO}_{2} \mathrm{NH}_{4} \mathrm{PO}_{4}$ curve. $U(V I)$ compounds are stable in an oxidizing environment and U(IV) compounds are stable in a reducing environment. Consistent with the thermodynamic data is the observation that carnotite, a U(VI) mineral is found in the oxidized zones of uranium ore deposits and uraninite, a U(IV) mineral is a primary mineral in reducing ore zones.

The thermodynamic data for solution species of uranium are reported in Table 15. All the species except $\mathrm{UO}_{2}{ }^{+}$shown in Figure 29 are of $\mathrm{U}(\mathrm{VI})$. Since equilibrium is assumed with $\mathrm{Na}_{2} \mathrm{UO}_{4}$, a $U(V I)$ compound, a change in oxidationreduction conditions will affect the position of the curves. In an oxidizing environment $\left(\mathrm{pO}_{2}=0.68 \mathrm{~atm}\right)$, the $U(\mathrm{IV})$ species are very low in concentration $\left(\log a_{j}<38\right)$ and fall outside of the boundaries of Figure 29.

Figure 29 shows that $U(V I)$ species will control the solution concentration in an oxidizing environment. $\mathrm{UO}_{2}{ }^{2+}$ is the predominant solution species up to a $\mathrm{pH}$ of approximately 6 . The predominant solution species over $\mathrm{pH}$ ranges of from 6 to 8 and $>8$ are $\mathrm{UO}_{2}(\mathrm{OH})_{2}^{\circ}$ and $\mathrm{UO}_{2}\left(\mathrm{CO}_{3}\right)_{3}{ }^{4-}$, respectively. 


\section{TABLE 15. Selected Equilibrium Constants (K) at $25^{\circ} \mathrm{C}$ and One Atmosphere Pressure for Reactions Involving Uranium}

\begin{tabular}{|c|c|c|c|c|}
\hline \multicolumn{2}{|c|}{ Reaction } & Medium & \multirow{2}{*}{$\underline{\log K}$} & \multirow[t]{2}{*}{ Reference } \\
\hline \multicolumn{3}{|c|}{ Uranium (III \& IV) Compounds } & & \\
\hline $\mathrm{U}(\mathrm{OH})_{3}$ & $+\mathrm{U}^{3+}+3 \mathrm{OH}^{-}$ & 0 & -19.29 & Latimer (1952) \\
\hline $\mathrm{U}(\mathrm{OH})_{4}$ & $\pm \mathrm{U}^{4+}+4 \mathrm{OH}^{-}$ & 0 & -46.23 & $"$ \\
\hline $\mathrm{UF}_{4} 2 \cdot 5 \mathrm{H}_{2} \mathrm{O}$ & $\stackrel{+}{+} \mathrm{U}^{4+}+4 \mathrm{~F}^{-}+2 \cdot 5 \mathrm{H}_{2} \mathrm{O}$ & Var & -21.24 & $\begin{array}{l}\text { Sillen and } \\
\text { Martell (1964) }\end{array}$ \\
\hline $\mathrm{UO}_{2}+4 \mathrm{H}^{+}$ & $\rightleftarrows \mathrm{U}^{4+}+2 \mathrm{H}_{2} 0$ & 0 & 3.63 & $\begin{array}{l}\text { Garrels and } \\
\text { Christ }(1965)\end{array}$ \\
\hline $\mathrm{U}\left(\mathrm{HPO}_{4}\right)_{2}$ & $\pm U^{4+}+2 \mathrm{HPO}_{4}^{2-}$ & 0 & -17.51 & Palei (1962) \\
\hline $\mathrm{U}(\mathrm{OH})_{2} \mathrm{SO}_{4}$ & $\overrightarrow{+} \mathrm{U}^{4+}+2 \mathrm{OH}^{-}+\mathrm{SO}_{4}{ }^{2-}$ & 0 & -31.17 & $\begin{array}{l}\text { Sillen and } \\
\text { Marte1l (1964) }\end{array}$ \\
\hline
\end{tabular}

Uranium (VI) Compounds

\begin{tabular}{|c|c|c|c|c|}
\hline $\mathrm{UO}_{2} \mathrm{KAsO}_{4}$ & $\rightleftarrows \mathrm{UO}_{2}^{2+}+\mathrm{K}^{+}+\mathrm{AsO}_{4}^{3-}$ & 0 & -22.60 & Palei (1962) \\
\hline $\mathrm{UO}_{2} \mathrm{NaAsO}_{4}$ & $\overrightarrow{+} \mathrm{UO}_{2}^{2+}+\mathrm{Na}^{+}+\mathrm{AsO}_{4}^{3-}$ & 0 & -21.87 & $"$ \\
\hline $\mathrm{UO}_{2} \mathrm{NH}_{4} \mathrm{AsO}_{4}$ & $\vec{f} \mathrm{UO}_{2}^{2+}+\mathrm{NH}_{4}^{+}+\mathrm{AsO}_{4}^{3-}$ & 0 & -23.77 & $"$ \\
\hline $\mathrm{UO}_{3}+2 \mathrm{H}^{+}$ & $+\mathrm{UO}_{2}^{2+}+\mathrm{H}_{2} \mathrm{O}$ & 0 & 14.77 & $\begin{array}{l}\text { Garrels and } \\
\text { Christ (1965) }\end{array}$ \\
\hline $\mathrm{UO}_{3} \mathrm{H}_{2} \mathrm{O}+2 \mathrm{H}^{+}$ & $\overrightarrow{+} \mathrm{UO}_{2}^{2+}+2 \mathrm{H}_{2} \mathrm{O}$ & 0 & 5.01 & Latimer (1952) \\
\hline $\mathrm{UO}_{2}(\mathrm{OH})_{2}+2 \mathrm{H}^{+}$ & $\overrightarrow{+} \mathrm{UO}_{2}^{2+}+2 \mathrm{H}_{2} \mathrm{O}$ & 0 & 4.97 & $\begin{array}{l}\text { Sillen and } \\
\text { Martell (1964) }\end{array}$ \\
\hline $\mathrm{UO}_{2}(\mathrm{OH})_{2} \mathrm{H}_{2} \mathrm{O}+2 \mathrm{H}^{+}$ & $\overrightarrow{+} \mathrm{UO}_{2}^{2+} 3 \mathrm{H}_{2} \mathrm{O}$ & 0 & 5.6 & " \\
\hline $\mathrm{Na}_{2} \mathrm{UO}_{4}+4 \mathrm{H}^{+}$ & 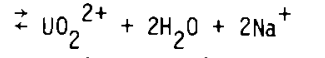 & 0 & -0.07 & Latimer (1952) \\
\hline $\mathrm{UO}_{2} \mathrm{CO}_{3}$ & $\pm \mathrm{UO}_{2}^{2+}+2 \mathrm{CO}_{3}^{2-}$ & 0 & -10.54 & $\begin{array}{l}\text { Garrels and } \\
\text { Christ (1965) }\end{array}$ \\
\hline $\mathrm{Na}_{4} \mathrm{UO}_{2}\left(\mathrm{CO}_{3}\right)_{3}$ & $+\mathrm{UO}_{2}{ }^{2+}+4 \mathrm{Na}{ }^{+}+3 \mathrm{CO}_{3}{ }^{2-}$ & 0 & -21.1 & $\begin{array}{l}\text { Silien and } \\
\text { Martell (1964) }\end{array}$ \\
\hline$\left(\mathrm{UO}_{2}\right)_{3}\left(\mathrm{PO}_{4}\right)_{2}$ & $\pm 3 \mathrm{UO}_{2}^{2+}+2 \mathrm{PO}_{4}^{3-}$ & 0 & -46.33 & Palei (1962) \\
\hline $\mathrm{UO}_{2} \mathrm{HPO}_{4}$ & $\pm \mathrm{UO}_{2}^{2+}+\mathrm{HPO}_{4}^{2-}$ & 0 & -10.67 & $"$ \\
\hline $\mathrm{UO}_{2} \mathrm{KPO}_{4}$ & $\stackrel{\mathrm{UO}_{2}}{2+}+\mathrm{K}^{+}+\mathrm{PO}_{4}^{3-}$ & 0 & -23.11 & " \\
\hline $\mathrm{UO}_{2} \mathrm{NH}_{4} \mathrm{PO}_{4}$ & $\overrightarrow{+} \mathrm{UO}_{2}^{2+}+\mathrm{NH}_{4}^{+}+\mathrm{PO}_{4}^{3-}$ & 0 & -26.36 & $"$ \\
\hline $\mathrm{UO}_{2}\left(\mathrm{SO}_{4}\right) 3 \mathrm{H}_{2} \mathrm{O}$ & $+\mathrm{UO}_{2}^{2+}+\mathrm{SO}_{4}^{2-}+3 \mathrm{H}_{2} \mathrm{O}$ & 0 & -1.57 & Latimer (1952) \\
\hline \multicolumn{5}{|c|}{ Oxidation-Reduction Reactions } \\
\hline$u^{3+}+3 e^{-}$ & $\vec{f} U(s)$ & 0 & -91.0 & $\begin{array}{l}\text { Sillen and } \\
\text { Martell (1964) }\end{array}$ \\
\hline $\mathrm{u}^{4+}+\mathrm{e}^{-}$ & $\vec{f} u^{3+}$ & 0 & -10.3 & $"$ \\
\hline $\mathrm{UO}_{2}^{+}+4 \mathrm{H}^{+}+\mathrm{e}^{-}$ & $\vec{*} U^{4+}+2 \mathrm{H}_{2} \mathrm{O}$ & 0 & 10.19 & $"$ \\
\hline $\mathrm{UO}_{2}^{2+}+\mathrm{e}^{-}$ & $\rightleftarrows \mathrm{UO}_{2}^{+}$ & 0 & 0.88 & $"$ \\
\hline $\mathrm{NO}_{2}^{2+}+4 \mathrm{H}^{+}+2 \mathrm{e}^{-}$ & $\rightleftarrows \mathrm{U}^{4+}+2 \mathrm{H}_{2} \mathrm{O}$ & 0 & 11.07 & $"$ \\
\hline
\end{tabular}


TABLE 15. (Continued)

\section{$\operatorname{Medium}(a) \quad \underline{\log K}$}

Reference

\section{Hydrolysis Reactions}

\begin{tabular}{|c|c|c|c|c|}
\hline $\mathrm{U}^{4+}+\mathrm{H}_{2} \mathrm{O}$ & $\vec{\leftarrow} \mathrm{UOH}^{3+}+\mathrm{H}^{+}$ & 0 & -1.00 & $\begin{array}{l}\text { Garrels and } \\
\text { Christ (1965) }\end{array}$ \\
\hline $\mathrm{U}^{4+}+2 \mathrm{H}_{2} \mathrm{O}$ & $\rightarrow \mathrm{U}(\mathrm{OH})_{2}^{2+}+2 \mathrm{H}^{+}$ & Var & -2.30 & $\begin{array}{l}\text { Sillen and } \\
\text { Martel1 (1964) }\end{array}$ \\
\hline $\mathrm{UO}_{2}^{2+}+\mathrm{H}_{2} \mathrm{O}$ & 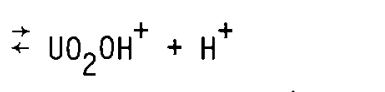 & 0 & -4.14 & $"$ \\
\hline $\mathrm{UO}_{2}{ }^{2+}+2 \mathrm{H}_{2} \mathrm{O}$ & $\vec{\leftarrow} \mathrm{UO}_{2}(\mathrm{OH})_{2}^{\circ}+2 \mathrm{H}^{+}$ & 0 & -12.02 & $"$ \\
\hline $\mathrm{UO}_{2}{ }^{2+}+3 \mathrm{H}_{2} \mathrm{O}$ & $\stackrel{+}{\leftarrow} \mathrm{OO}_{2}(\mathrm{OH})_{3}^{-}+3 \mathrm{H}^{+}$ & 0 & -23.64 & $"$ \\
\hline $\mathrm{UO}_{2}^{2+}+4 \mathrm{H}_{2} \mathrm{O}$ & 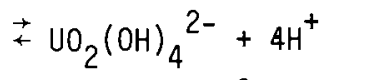 & 0 & -37.81 & $"$ \\
\hline $2 \mathrm{UO}_{2}{ }^{2+}+2 \mathrm{H}_{2} \mathrm{O}$ & $\rightleftarrows\left(\mathrm{UO}_{2}\right)_{2}(\mathrm{OH})_{2}^{2+}+2 \mathrm{H}^{+}$ & 0 & -5.06 & $"$ \\
\hline \multicolumn{5}{|c|}{ Other Reactions } \\
\hline $\mathrm{UO}_{2}{ }^{2+}+2 \mathrm{CO}_{3}^{2-}$ & $\stackrel{\mathrm{UO}_{2}}{ }\left(\mathrm{CO}_{3}\right)_{2}^{2-}$ & 0 & 14.6 & $\begin{array}{l}\text { Sillen and } \\
\text { Martel1 (1964) }\end{array}$ \\
\hline $\mathrm{UO}_{2}{ }^{2+}+3 \mathrm{CO}_{3}{ }^{2-}$ & $\stackrel{\mathrm{UO}_{2}}{2}\left(\mathrm{CO}_{3}\right)_{3}^{4-}$ & 0 & 18.3 & $"$ \\
\hline $\mathrm{U}^{4+}+\mathrm{Cl}^{-}$ & $\rightleftarrows \mathrm{UCl}^{3+}$ & 0 & 0.8 & $"$ \\
\hline $\mathrm{UO}_{2}^{2+}+\mathrm{Cl}^{-}$ & $\stackrel{\leftrightarrow}{\leftarrow} \mathrm{UO}_{2} \mathrm{Cl}^{+}$ & 0 & 0.21 & $"$ \\
\hline $\mathrm{U}^{4+}+\mathrm{F}^{-}$ & $\vec{t} \mathrm{UF}^{3+}$ & $0.12\left(\mathrm{HClO}_{4}\right)$ & 7.15 & $"$ \\
\hline$U^{4}+2 F^{-}$ & $+\mathrm{UF}_{2}^{2+}$ & $0.12\left(\mathrm{HClO}_{4}\right)$ & 12.40 & $"$ \\
\hline $\mathrm{U}^{4}+3 \mathrm{~F}^{-}$ & $\stackrel{+}{*} \mathrm{UF}_{3}^{+}$ & $0.12\left(\mathrm{HClO}_{4}\right)$ & 17.30 & $"$ \\
\hline $\mathrm{UO}_{2}^{2+}+\mathrm{F}^{-}$ & $\vec{\leftarrow} \mathrm{UO}_{2} \mathrm{~F}^{+}$ & 1.0 at $20^{\circ} \mathrm{C}$ & 4.54 & Palei (1962) \\
\hline $\mathrm{UO}_{2}{ }^{2+}+\mathrm{H}_{3} \mathrm{PO}_{4}$ & $\stackrel{+}{\leftarrow} \mathrm{UO}_{2} \mathrm{H}_{2} \mathrm{PO}_{4}^{+}+\mathrm{H}^{+}$ & 1.06 & 1.19 & $"$ \\
\hline $\mathrm{U}^{4+}+\mathrm{HSO}_{4}^{-}$ & $\stackrel{\mathrm{USO}_{4}}{2+}+\mathrm{H}^{+}$ & 0 & 2.41 & $\begin{array}{l}\text { Sillen and } \\
\text { Martell (1964) }\end{array}$ \\
\hline $\mathrm{U}^{4+}+2 \mathrm{HSO}_{4}^{-}$ & $\vec{\leftarrow} U\left(\mathrm{SO}_{4}\right)_{2}^{\circ}+2 \mathrm{H}^{+}$ & 0 & 3.73 & $"$ \\
\hline $\mathrm{UO}_{2}^{2+}+\mathrm{SO}_{4}^{2-}$ & 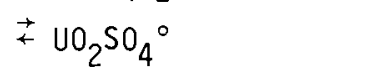 & 0 & 2.76 & $"$ \\
\hline
\end{tabular}

(a) The nature of the medium to which the equilibrium constants refer, for example, 0 - zero ionic strength, var - ionic medium varied, $2\left(\mathrm{HClO}_{4}\right)$ - ionic strength held constant at the value stated ( 2 moles/liter) by the addition of the chemical shown in parentheses, 1.0 $\mathrm{HClO}_{4}$ - constant concentration of the substance stated $\left(1.0\right.$ moles/liter $\left.\mathrm{HClO}_{4}\right)$. 


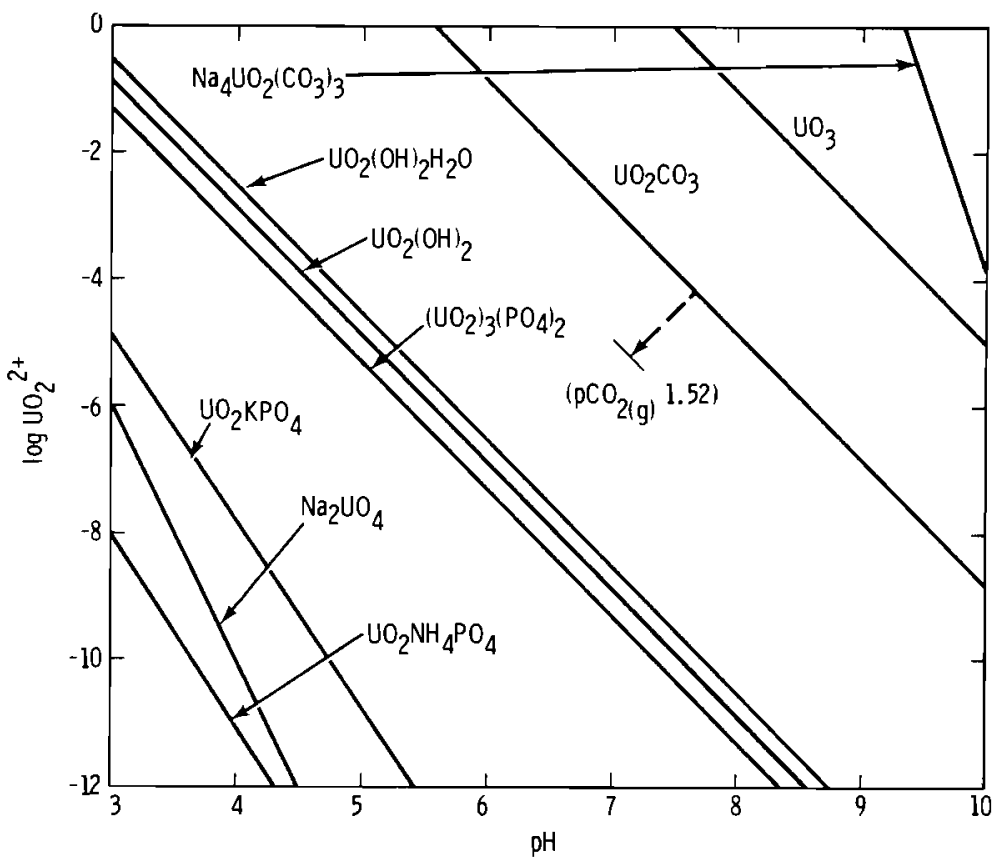

FIGURE 28. The Relative Stability of Various Solids in an Oxjdizing Environment $\left[\mathrm{pO}_{2}=0.68\right], \mathrm{pCO}_{2}=3.52$, $\mathrm{pK}^{+}=\mathrm{pNa}^{+}=3.0$ and Phosphate Levels in Equilibrium with Variscite and Gibbsite 


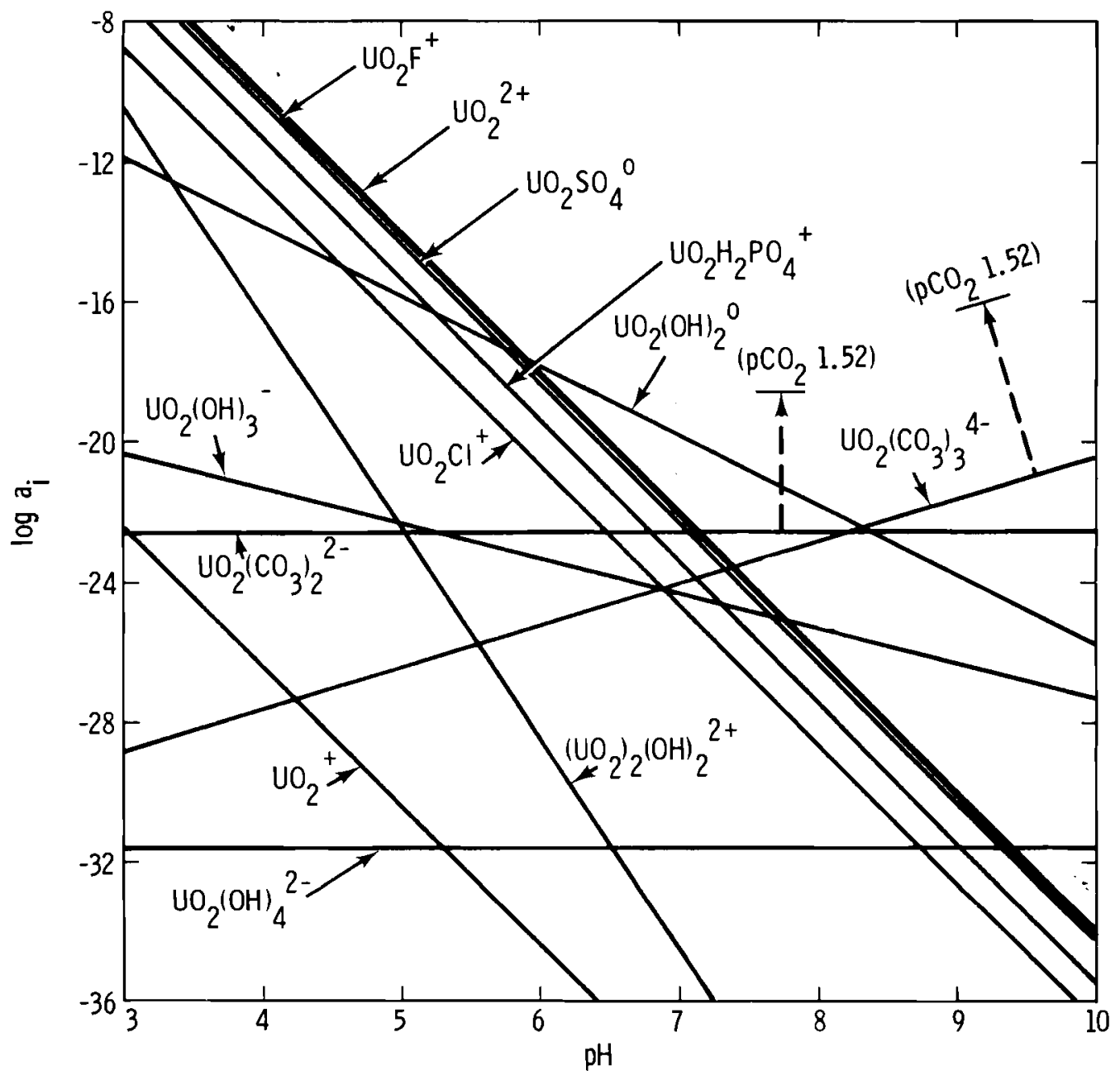

FIGURE 29. Activity of Various Uranium Species in Equilibrium with $\mathrm{Na}_{2} \mathrm{UO}_{4}$ in Oxidizing Soil Environment $\left(\mathrm{pO}_{2}=0.68\right)$, $\mathrm{pCO}_{2}=3.52, \mathrm{pCl}^{-}=\mathrm{pSO}_{4}^{-}=3.0, \mathrm{pF}^{-}=4.5$ and $\mathrm{pH}_{2} \mathrm{PO}_{4}=5.0$ 
PREDICTED VS. OBSERVED BEHAVIOR OF URANIUM

The common oxidation states of uranium are U(III), U(IV), U(V), and $U(V I)$ (Udaltsova, 1963). However, in the geologic environment U(IV) and $U(V I)$ are the most important oxidation states. In oxidizing environments $\mathrm{U}\left(\mathrm{VI}\right.$ ) compounds such as $\mathrm{KUO}_{2} \mathrm{VO}_{4}$ (Garrels and Christ, 1965), $\mathrm{UO}_{2} \mathrm{NH}_{4} \mathrm{PO}_{4}$, $\mathrm{Na}_{2} \mathrm{UO}_{4}$ and $\mathrm{UO}_{2} \mathrm{KPO}_{4}$ (Figure 28) are stable and can precipitate. U(IV) would precipitate as $\mathrm{UO}_{2}$ in a reducing environment. $U(V I)$ solution species govern uranium concentrations and movement in oxidizing environments (Figure 29). Uranium retention by soils and rocks in alkaline conditions is poor because the predominant uranium species at $\mathrm{pH}>6$ in oxidizing environments (Figure 29) are either neutral or negatively charged. An increase in $\mathrm{CO}_{2}$ pressure in soil solutions reduces uranium adsorption and can increase uranium concentration. The cation exchange properties of soils could contribute to the adsorption of uranium in the neutral to acidic $\mathrm{pH}$ range due to the presence of $\mathrm{UO}_{2}^{2+}$. Oxidation-reduction conditions and $\mathrm{pH}$ would be important parameters of uranium mobilization and immobilization.

The above theoretically based predictions are substantiated by experimental results. Uranium has been reported to be solubilized and highly mobile in carbonate-containing waters (Brown and Keller, 1952; Naumov, 1961; Ermolaev et a1., 1965; Legin et a1., 1966; Haglund, 1968; Haglund et a1., 1969). Soluble uranium $[U(V I)]$ can:

1. precipitate in the presence of phosphorus as evidenced by a direct correlation of uranium and phosphate content in soils and rocks (Be11, 1960; Sakanoue, 1960; Habashi, 1962; Kuznetsov et a1., 1968)

2. be adsorbed by the soil organic component and/or reduced to U(IV) followed by precipitation (Breger et a1., 1955; Kolodny, 1969; Kolodny and Kaplan, 1970; Baturin, 1971; Da11'Aglio, 1971; Dorta and Rona, 1971; Gabelman, 1971; Baturin and Kochenov, 1973; Mo et a1., 1973)

An increase in uranium content with a decrease in soil or sediment particle size was reported by several workers (Kovalevskii, 1967; Mizuno and Mochizuki, 1970; Ritchie et a1., 1972). 
ZIRCONIUM

The selected thermodynamic data for zirconium minerals are reported in Table 16. The solubility of different zirconium minerals with the changes in $\mathrm{pH}$ is shown in Figure 30 . The zirconium minerals in increasing order of stability are: $\mathrm{Zr}(\mathrm{OH})_{4}, \mathrm{ZrO}_{2}$, and $\mathrm{ZrSiO}_{4}$, as shown in Figure 30 . The most stable mineral throughout the $\mathrm{pH}$ range is zircon $\left(\mathrm{ZrSiO}_{4}\right)$. This is consistent with the empirical observations of many geologists and soil scientists who find that zircon $\left(\mathrm{ZrSiO}_{4}\right)$ is ubiquitous in soils and is very stable even compared to other common soil minerals.

The activity of various solution species with the change in $\mathrm{pH}$ and in

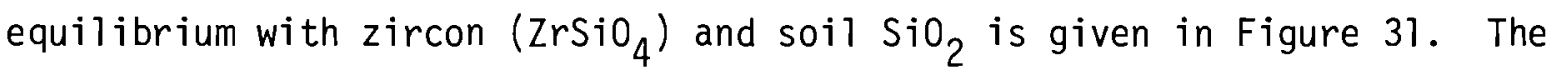
thermodynamic data for solution species are reported in Table 16. Zirconium forms complexes with the common soil anions $\left(\mathrm{F}^{-}, \mathrm{Cl}^{-}, \mathrm{SO}_{4}{ }^{2-}, \mathrm{NO}_{3}{ }^{-}\right)$. The significance of complexation of zirconium with these anions decreases in the following order: $\mathrm{F}^{-}, \mathrm{SO}_{4}{ }^{2-}, \mathrm{Cl}^{-}, \mathrm{NO}_{3}{ }^{-}$. Although zirconium forms complexes with common soil anions, $\mathrm{ZrF}^{3+}$ complex would be the only one which could contribute significantly in acidic environments $(\mathrm{pH} 3.5)$ to the total zirconium in solution. It can be seen from the diagram that the uncomplexed zirconium $\left(\mathrm{Zr}^{4+}\right)$ would exist in significant amounts only in very acidic solutions $(\mathrm{pH}<1)$. The zirconium ions are hydrolyzed in solutions with $\mathrm{pH}$ values of greater than 1.0. The most dominant zirconium solution species with the conditions assumed in Figure 31 are $\mathrm{ZrF}^{3+}, \mathrm{Zr}(\mathrm{OH})_{4}^{\circ}$, and $\mathrm{Zr}(\mathrm{OH})_{5}{ }^{-}$ in $\mathrm{pH}$ ranges of $<3.5,3.5-6.25$, and $>6.25$, respectively.

If a waste solution containing zirconium is assumed to be in equilibrium with zircon and the conditions assumed in Figure 31 , then the total activity of zirconium in solution would be lower than $10^{-14}$ over a $\mathrm{pH}$ range of 3.5 to 8 .

The $\mathrm{Zr}^{4+}$ ion becomes increasingly hydrolyzed above $\mathrm{pH} 1$ (Figure 31). The $\mathrm{Zr}^{4+}$ content of the soil solution falls rapidly, as does the content of fluoride complex $\mathrm{ZrF}^{3+}$, in favor of hydrolyzed species at higher $\mathrm{pH}$ values. Only at relatively low pH values of less than 4 do positively charged species 
of zirconium predominate. Because most soils and rocks buffer waters contacting them to $\mathrm{pH} 5$ of higher, ion exchange probably plays a relatively minor role in zirconium retention by soils and rocks. Because of the formation of negatively charged complexes in solutions of $\mathrm{pH}>6.5$ (Figure 31 ), zirconium adsorption would be expected to decrease with an increase in $\mathrm{pH}$ above 6.5 . 
TABLE 16. Selected Equilibrium Constants (K) at $25^{\circ} \mathrm{C}$ and One Atmosphere Pressure for Reactions Involving Zirconium

\author{
Reaction
}

Medium (a) $\underline{\log K}$

Reference

Solid Compounds

$\begin{array}{lcccc}\mathrm{Zr}(\mathrm{OH})_{4} & \stackrel{\mathrm{Zr}^{4+}+4 \mathrm{H}^{-}}{ } & \text {Variable } & -52.0 & \text { Sillen and Martell (1964) } \\ \mathrm{ZrO}_{2}+4 \mathrm{H}^{+} & \rightleftarrows \mathrm{Zr}^{4+}+2 \mathrm{H}_{2} \mathrm{O} & 0 & -1.9 & \text { Baes and Mesmer (1976) } \\ \mathrm{ZrSiO}_{4}+4 \mathrm{H}^{+} & \rightleftarrows \mathrm{Zr}^{4+}+\mathrm{H}_{4} \mathrm{SiO}_{4} & 0 & -3.59 & \begin{array}{l}\text { Wagman et a } 1 .(1971) ; \text { and } \\ \text { Helgeson (1969) }\end{array}\end{array}$

Hydrolysis and Other Reactions

\begin{tabular}{|c|c|c|c|c|}
\hline $\mathrm{Zr}^{4+}+\mathrm{F}^{-}$ & $\rightarrow \mathrm{ZrF}^{3+}$ & 0 & 9.80 & Sillen and Martell (1964) \\
\hline $\mathrm{Zr}^{4+}+\mathrm{Cl}^{-}$ & $\stackrel{\mathrm{ZrCl}}{3+}$ & $\left(2: \mathrm{HClO}_{4}\right)$ & 0.30 & " \\
\hline $\mathrm{Zr}^{4+}+\mathrm{SO}_{4}^{2-}$ & $\rightarrow \mathrm{ZrSO}_{4}^{2+}$ & $\left(2 \mathrm{HClO}_{4}\right)$ & 3.79 & 11 \\
\hline $\mathrm{Zr}^{4+}+\mathrm{NO}_{3}^{-}$ & $\stackrel{\mathrm{ZrNO}_{3}^{3+}}{3+}$ & $\left(2 \mathrm{HClO}_{4}\right)$ & 0.3 & " \\
\hline $\mathrm{Zr}^{4+}+\mathrm{H}_{2} \mathrm{O}$ & $\because \mathrm{ZrOH}^{3+}+\mathrm{H}^{+}$ & 0 & 0.3 & Baes and Mesmer (1976) \\
\hline $\mathrm{Zr}^{4+}+2 \mathrm{H}_{2} \mathrm{O}$ & 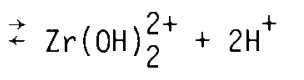 & 0 & -1.7 & $"$ \\
\hline $\mathrm{Zr}^{4+}+3 \mathrm{H}_{2} \mathrm{O}$ & $\vec{Z} \mathrm{Zr}(\mathrm{OH})_{3}^{+}+3 \mathrm{H}^{+}$ & 0 & -5.1 & $"$ \\
\hline $\mathrm{Zr}^{4+}+4 \mathrm{H}_{2} \mathrm{O}$ & 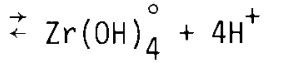 & 0 & -9.7 & $"$ \\
\hline $\mathrm{Zr}^{4+}+5 \mathrm{H}_{2} \mathrm{O}$ & $\overrightarrow{\mathrm{Zr}}(\mathrm{OH})_{5}^{-}+5 \mathrm{H}^{+}$ & 0 & -16.0 & $"$ \\
\hline $3 Z r^{4+}+4 \mathrm{H}_{2} \mathrm{O}$ & $\stackrel{\rightarrow}{ } \mathrm{Zr}_{3}(\mathrm{OH})_{4}^{8+}+4 \mathrm{H}^{+}$ & 0 & -0.6 & $"$ \\
\hline $3 \mathrm{Zr}^{4+}+5 \mathrm{H}_{2} \mathrm{O}$ & $\stackrel{\rightarrow}{\mathrm{Zr}_{3}}(\mathrm{OH})_{5}^{7+}+5 \mathrm{H}^{+}$ & 0 & 3.7 & $"$ \\
\hline
\end{tabular}

(a) The nature of the medium to which the equilibrium constants refer, for example, 0 - zero ionic strength, var - ionic medium varied, $2\left(\mathrm{HC}_{10} \mathrm{O}_{4}\right.$ - ionic strength held constant at the value stated ( 2 moles/liter) by the addition of the chemical shown in parentheses, 1.0 $\mathrm{HClO}_{4}$ - constant concentration of the substance stated ( 1.0 moles/liter $\left.\mathrm{HClO}_{4}\right)$. 


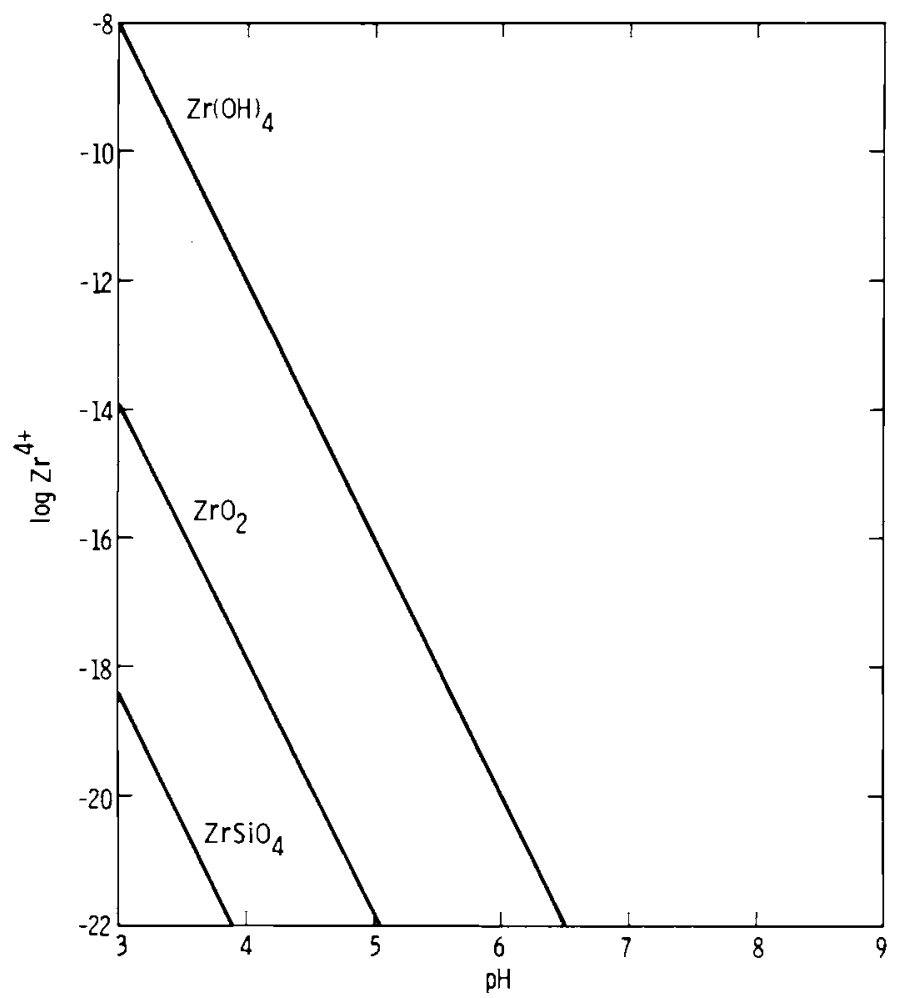

FIGURE 30. The Stability of Zirconium Solids in Equilibrium with Soil Silica $\left(\mathrm{pH}_{4} \mathrm{SiO}_{4}=3.1\right)$ 


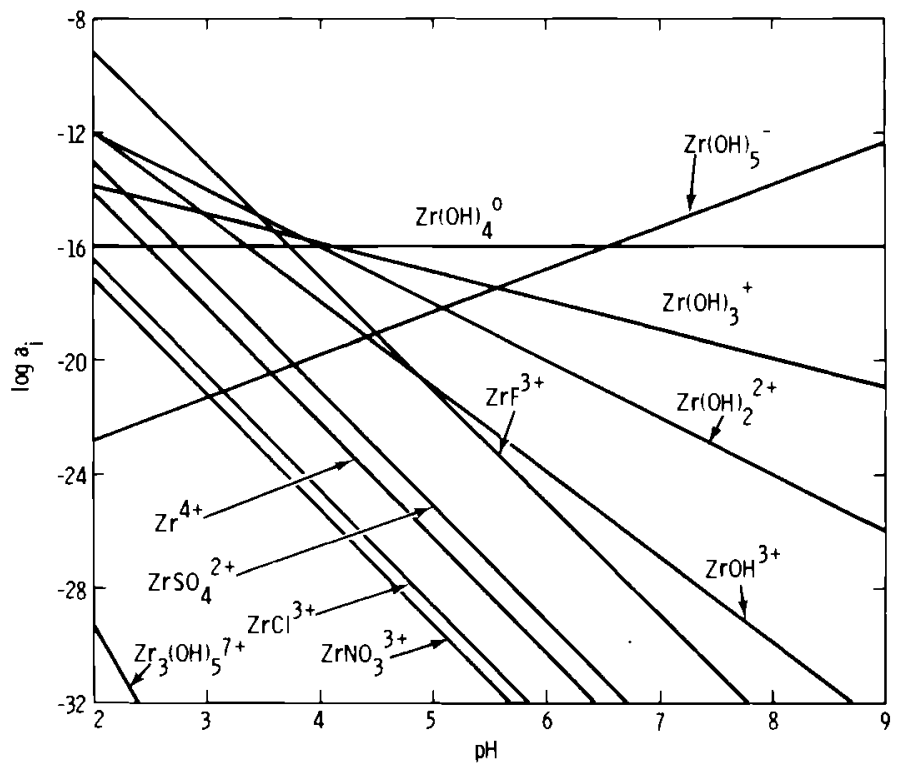

FIGURE 31. The Activity of Various Zirconium Species in Equilibrium with Soil Silica $_{2} \mathrm{pH}_{4} \mathrm{SiO}_{4}$ $=3.1)$ and at $\mathrm{pCl}^{-}=\mathrm{pSO}_{4}^{2-}=2.5, \mathrm{pNO}_{3}^{-}=$
$3.0, \mathrm{pF}^{-}=4.5$ 


\section{PREDICTED VS. OBSERVED BEHAVIOR OF ZIRCONIUM}

Trace concentrations of zirconium are strongly adsorbed on soils at $\mathrm{pH} 1$ or higher with a dip in Kd values between $\mathrm{pH} 8$ to 12 (Rhodes, 1957), probably due to the prevalence of uncharged or anionic zirconium species over this $\mathrm{pH}$ range (Figure 31 ). There is some evidence for affects caused by competing cations at near-neutral $\mathrm{pH}$, suggesting at least partial removal by an ion exchange mechanism of polymerized or colloidal species (Eichholz et a1., 1967; Harrison, 1969). Zirconium is well-adsorbed by the soil over the normal $\mathrm{pH}$ range of 4 to 8 (Spitsyn et al., 1958; Schu1z, 1965; Magno et al., 1970). Carbonate, oxalate and citrate complexes of zirconium have been reported to migrate rapidly through soil columns (Bensen, 1960). 


\section{SUMMARY AND CONCLUSIONS}

Among the factors that determine the fate of a given element in the environment, the solid phases, the total concentration and the type of solution species are the most important. Laboratory information on possible solid phases and solution species of elements of interest (Am, Sb, Ce, Cs, $\mathrm{Co}, \mathrm{Cm}, \mathrm{Eu}, \mathrm{I}, \mathrm{Np}, \mathrm{Pm}, \mathrm{Ra}, \mathrm{Ru}, \mathrm{Sr}, \mathrm{Tc}, \mathrm{Th},{ }_{H}, \mathrm{Zr}$ ) in radioactive waste is almost nonexistent (Ames and Rai, 1978). Therefore, thermodynamic data for these elements were used to predict the stable species and the degree of adsorption of these species by the solid matrix. The limitations of these predictions are discussed. These predictions are also compared with observations reported in literature.

The solid compounds of different elements that are considered in this report are those for which thermodynamic data are available. Among the compounds for which thermodynamic data are available, there are many that are very soluble. These compounds are unlikely to occur under environmental conditions. Some of the most stable compounds of different elements that 1) may occur in geologic environments, or 2) those that would be helpful in selecting radionuclide concentrations for adsorption experiments, include $\mathrm{Sb}_{2} \mathrm{O}_{5}, \mathrm{Sb}_{2} \mathrm{~S}_{3}, \mathrm{CePO}_{4}, \mathrm{CoOOH}, \mathrm{CoCO}_{3}, \mathrm{Cm}(\mathrm{OH})_{3}, \mathrm{Eu}(\mathrm{OH})_{3}, \mathrm{NpO}_{2}, \mathrm{PuO}_{2}, \mathrm{Pu}(\mathrm{OH})_{4}$, $\mathrm{Pm}(\mathrm{OH})_{3}, \mathrm{RuO}_{2}, \mathrm{SrCO}_{3}, \mathrm{ThO}_{2}, \mathrm{Th}_{(\mathrm{OH})_{4}}, \mathrm{UO}_{2} \mathrm{NH}_{4} \mathrm{PO}_{4}, \mathrm{KUO}_{2} \mathrm{VO}_{4}, \mathrm{UO}_{2}, \mathrm{ZrSiO}_{4}, \mathrm{ZrO}_{2}$, $\mathrm{Zr}(\mathrm{OH})_{4}$.

The predicted nature of the predominant solution species of various elements are reported in Table 17. The environmental conditions assumed for Table 17 data include a $\mathrm{pH}$ range of 4 to $9, \mathrm{pO}_{2}$ range of 0.68 to 80 atmospheres, $\mathrm{pCO}_{2}$ of 1.52 to 3.52 atmospheres, $\mathrm{pCl}^{-}=\mathrm{pNO}_{3}{ }^{-}=\mathrm{pSO}_{4}^{2-}=3.0, \mathrm{pF}^{-} 4.5$, and $\mathrm{PH}_{2} \mathrm{PO}_{4}^{-}$5.0. It should be pointed out that a change in these environmental conditions, in addition to the ligands not considered in the above assumptions, may change the nature of the solution species. Depending upon the given chemical environment, several species of an element can exist in solution. Cesium, cobalt, promethium, radium, strontium, and tritium would be expected to exist predominantly as uncomplexed solution species: $\mathrm{Cs}^{+}, \mathrm{Co}^{2+}, \mathrm{Pm}^{3+}$, $\mathrm{Ra}^{2+}, \mathrm{Sr}^{2+}$ and ${ }^{3} \mathrm{H}^{+}$(or $\mathrm{T}$ ). Certain elements such as plutonium, neptunium 
and uranium can exist in acidic solutions in an oxidizing environment as uncomplexed solution ions $\left(\mathrm{PuO}_{2}^{+}, \mathrm{PuO}_{2}^{2+}, \mathrm{NpO}_{2}^{+}, \mathrm{UO}_{2}^{2+}\right)$. Some of the elements such as curium, thorium and zirconium hydrolyze very readily even in acidic environments, so they mainly exist as hydrolyzed species $\left[\mathrm{CmOH}_{0}^{2+}, \mathrm{Cm}(\mathrm{OH})_{2}^{+}\right.$, $\left.\mathrm{Th}(\mathrm{OH})_{3}^{+}, \mathrm{Zr}(\mathrm{OH})_{4}^{\circ}, \mathrm{Zr}(\mathrm{OH})_{5}^{-}\right]$. Some of the common soil ligands $\left(\mathrm{CO}_{3}^{2-}, \mathrm{SO}_{4}^{2-}\right)$ form strong complexes with americium, curium, europium, neptunium, plutonium and uranium so that these ligands would influence the concentration of these elements in solutions. Oxidation-reduction conditions would predominantly influence the nature of the solution species of antimony, neptunium, plutonium, technetium, and uranium.

Based upon the nature of the predominant solution species, qualitative predictions regarding the adsorption and movement of various elements can be made. Soils and sediments mainly show cation exchange capacities (since these materials carry a large net negative charge) and to a limited extent, anion exchange capacities. Thus, most cations migrate through the soil or rock column at speeds slower than the groundwater. Relative to each other, the trivalent cations generally move the slowest, the divalent cations at intermediate velocities and the monovalent cations most rapidly. Tritium is unique in that it readily substitutes for hydrogen in water and migrates, therefore, at the same velocity as water. Complicating factors include a higher selectivity of a soil or rock component for a given cation or a more successful hydrogen ion competition with one cation relative to another. The relative mobilities of strontium and cesium at low $\mathrm{pH}$ is a good example of the latter effect. Strontium is much more mobile at low $\mathrm{pH}$ than is cesium.

The simple anions tend to migrate through soils and rocks with little reaction because usually a $\mathrm{pH}$ of less than 4 is required to activate a significant soil anion exchange capacity. However, both TC (in oxidizing environment) and I which exist predominantly as anions ( $\mathrm{I}^{-}, \mathrm{TCO}_{4}^{-}$) undergo other reactions with organic ligands that can greatly slow their migration.

The migration and retention of inorganic complex species (mononuclear and polynuclear) would also be dependent upon the charge and size of the species. Positively charged species would move slower than the negatively 
charged species. The highly charged metal ions tend to polymerize or form colloidal size, charged precipitates. The trivalent metal ions ( $\mathrm{Am}, \mathrm{Cm}, \mathrm{Sb}$, $\mathrm{Ru}$ ) and quadrivalent or higher charged metal ions ( $\mathrm{Pu}, \mathrm{Th}, \mathrm{U}, \mathrm{Zr}$ ) are known to form polymers. Initially, at lower $\mathrm{pH}$, the polymers are positively charged and at $\mathrm{pH} 8$ become increasingly negatively charged. The result is good adsorption and very slow movement at acidic to neutral $\mathrm{pH}$, and greatly lessened adsorption and rapid migration from pH 8 upward.

The behavior of organic complexed species of elements is difficult to predict because of the lack of knowledge regarding the exact nature of the organic ligands, a wide variation in amounts and types of organic ligands, and the size and solubility of these organics. These organic materials can either retain the element or complex it in a form that migrates readily. The source of these organic ligands can be the radioactive waste solutions containing the synthetic organic ligands such as TBP and/or the organic ligands produced by soil flora. 
TABLE 17. Predominant Solution Species of Elements in a pH 4 to $9, \mathrm{pO}_{2} 0.68$ to $80, \mathrm{pCO}_{2} 1.52$ to $3.52, \mathrm{pCl}^{-}=\mathrm{pNO}_{3-}=\mathrm{pSO}_{4}{ }^{2-}=3.0, \mathrm{pF}^{-} 4.5$ and $\mathrm{pH}_{2} \mathrm{PO}_{4}-5.0$ Environment Without Organic Ligands

Predominant Solution Species of Elements

\begin{tabular}{|c|c|c|c|}
\hline Elements & $\begin{array}{l}\text { Little Affected by } \\
\text { Oxidation-Reduction }\end{array}$ & $\begin{array}{c}\text { In An } \\
\text { Oxidizing Environment } \\
\end{array}$ & $\begin{array}{c}\text { In A } \\
\text { Reducing Environment } \\
\end{array}$ \\
\hline Am & $\mathrm{Am}^{3+}, \mathrm{AmSO}_{4}^{+}, \mathrm{AM}(\mathrm{OH})^{2+}$ & & \\
\hline Sb & & $\begin{array}{l}\mathrm{HSbO}_{2}{ }^{\circ}, \mathrm{Sb}(\mathrm{OH})_{3}{ }^{\circ}, \mathrm{SbOF}^{\circ}, \\
\mathrm{Sb}(\mathrm{OH})_{4}^{-}\end{array}$ & $\mathrm{SbO}^{+}$ \\
\hline $\mathrm{Ce}$ & $\mathrm{Ce}^{3+}, \mathrm{CeSO}_{4}^{+}$ & & \\
\hline Cs & $\mathrm{Cs}^{+}$ & & \\
\hline Co & $\mathrm{Co}^{2+}, \mathrm{Co}(\mathrm{OH})_{2}^{+}$ & & \\
\hline $\mathrm{Cm}$ & $\mathrm{Cm}^{3+}, \mathrm{CmOH}^{2+}, \mathrm{Cm}(\mathrm{OH})_{2}^{+}$ & & \\
\hline Eu & $\mathrm{Eu}^{3+}, \mathrm{EuSO}_{4}^{+}, \mathrm{Eu}_{2} \mathrm{P}_{2} \mathrm{O}_{7}{ }^{2+}$ & & \\
\hline I & $\overline{\mathrm{i}}^{-}, \mathrm{IO}_{3}^{-}$ & & \\
\hline $\mathrm{Np}$ & & $\begin{array}{l}\mathrm{NpO}_{2}^{+}, \mathrm{NpO}_{2} \mathrm{HPO}_{4}^{-}, \\
\mathrm{NpO}_{2}^{-} \mathrm{HCO}_{3}\end{array}$ & $\mathrm{NpOH}^{3+}, \mathrm{Np}^{4+}$ \\
\hline $\mathrm{Pu}$ & & $\begin{array}{l}\mathrm{PuO}_{2}^{2+}, \mathrm{PuO}_{2}\left(\mathrm{CO}_{3}\right)(\mathrm{OH})_{2}^{2-} \\
\mathrm{PuO}_{2}^{+}\end{array}$ & $\mathrm{PuOH}^{2+}, \mathrm{Pu}^{3+}$ \\
\hline $\mathrm{Pm}$ & $\mathrm{Pm}^{3+}$ & & \\
\hline $\mathrm{Ra}$ & $\mathrm{Ra}^{2+}$ & & \\
\hline Ru & & $\mathrm{Ru}(\mathrm{OH})_{2}^{2+}, \mathrm{RuO}_{4}{ }^{-}, \mathrm{RuO}_{4}{ }^{2-}$ & $\mathrm{RuO}_{4}^{-}$ \\
\hline $\mathrm{Sr}$ & $\mathrm{Sr}^{2+}$ & & \\
\hline Tc & & $\mathrm{TcO}_{4}^{-}$ & $\mathrm{Tc}^{2+}$ \\
\hline Th & $\mathrm{ThF}^{3+}, \mathrm{Th}(\mathrm{OH})_{3}^{+}$ & & \\
\hline $3^{H}$ & $\mathrm{H}^{+},{ }^{3} \mathrm{H}-0-\mathrm{H}$ & & \\
\hline U & & $\begin{array}{l}\mathrm{UO}_{2}^{2+}, \mathrm{UO}_{2} \mathrm{~F}^{+}, \mathrm{UO}_{2}\left(\mathrm{OH}_{2}\right)^{\circ}, \\
\mathrm{UO}_{2}\left(\mathrm{CO}_{3}\right)_{3}^{4-}\end{array}$ & $\begin{array}{l}\mathrm{UO}_{2}^{2+}, \mathrm{UOH}^{3+}, \mathrm{UO}_{2}^{+}, \\
\mathrm{UO}_{2}\left(\mathrm{CO}_{3}\right)_{3}^{4-}\end{array}$ \\
\hline $\mathrm{Zr}$ & $\begin{array}{l}\mathrm{Zr}(\mathrm{OH})_{4}{ }^{\circ}, \mathrm{Zr}(\mathrm{OH})_{5}^{-} \\
\mathrm{ZrF}^{3+}\end{array}$ & & \\
\hline
\end{tabular}




\section{REFERENCES}

INTRODUCTION AND METHODS AND MATERIALS

Ames, L. L. 1978. Radionuclide Interactions with Soil and Rock Media, Volume 2: Annotated bibliography (in two parts). Draft report to Office of Radiation Programs, U.S. Environmental Protection Agency.

Ames, L. L., and Dhanpat Rai. 1978. Radionuclide Interactions with Soil and Rock Media, Volume 1: Processes Influencing Radionuclide Mobility and Retention, Cement Chemistry and Geochemistry, Conclusions and Evaluation. Draft report to office of Radiation Programs, U.S. Environmental Protection Agency.

Baes, C. F., Jr. and R. F. Mesmer. 1976. The Hydrolys is of Cations. John Wiley and Sons, New York.

Burney, G. A. and R. M. Harbour. 1974. Radiochemistry of Neptunium. NAS-NRC Nuclear Sci. Ser. NAS-NS-3060.

Cleveland, J. M. 1970. The Chemistry of Plutonium, Gordon and Breach Science Publishers, New York.

Dutt, G. R., M. J. Shaffer and W. J. Moore. 1972. Computer Simulation Model of Biophysic - Cinemical Processes in Soils. University of Arizona, Tucson, Arizona. Agric. Exp. Stn. Tech. Bu11. 196.

Elgawhary, S. M., and W. L. Lindsay. 1972. Solubility of Silica in Soils. Soil Sci. Soc. Am. Proc. 36:439-442.

Fuger, J. and F. L. Detting. 1976. The Chemical Thermodynamics of Actinide Elements and Compounds, Part 2: The Actinide Aqueous Ions. International Atomic Energy Agency, Vienna.

Garrels, R. M. and C. L. Christ. 1965. Solutions, Minerals and Equilibria. Harper and Row. New York, pp. 213-216.

Helegeson, H. C. 1969. Thermodynamics of hydrothermal Systems at Elevated Temperatures and Pressures. Am. J. Sci. 267:729-804.

Holley, C. E., Jr., R. N. R. Mulford, E. J. Huber, Jr., E. L. Head, F. H. Ellinger, and C. W. Bjorklund. 1958. In: Proceedings of the second United Nations International Conference on the Peaceful Uses of Atomic Energy, Geneva, 6:215-220, (Quoted by Cleveland, 1970).

Jurinak, J. J. and J. Santillan - Medrano. 1974. The Chemistry and Transport of Lead and Cadmium in Soils. Utah State University, Logan Agric. Exp. Stn. Res. Rep. 18. 
Keller, C. 1971. The Chemistry of the Transuranium Elements. Vol. 3. Kernchemie in Einzeldarstellungen. Verlag Chemie/GmbH.

Latimer, W. M. 1952. Oxidation Potentials. Second Edition. PrenticsHa11, Englewood Cliffs, NJ.

Lindsay, W. L. 1972. Inorganic Phase Equilibria of Micronutrients in Soils. In: Micronutrients in Agriculture, pp. 41-57. Soil Sci. Soc. Amer. Inc., Madison, WI.

Lindsay, W. L., M. Peech, and J. J. Clark. 1959. Determination of Aluminum Ion Activity in Soil Extracts. Soil Sci. Soc. Am. Proc. 23:266-269.

Parker, V. B., D. D. Wagman, and W. H. Evans. 1971. Selected Values of Chemical Thermodynamic Properties. Tables for the Alkaline Earth Elements (Elements 92 through 97) in the Standard Order of Arrangement. NBS Technical Note 270-6.

Rai, Dhanpat and W. T. Franklin. 1973. Program for Computing Equilibrium Composition of $\mathrm{CaCO}_{3}$ and $\mathrm{CaSO}_{4}$ Systems from Irrigation Water Compositions. Council of U.S. Univ. for Soil and Water Develop. in Arid and Sub-Humid Areas. Water Manage. Tech. Rep. 29. Colo. State University, Fort Collins.

Rai, Dhanpat and W. L. Lindsay. 1975. A Thermodynamic Model for Predicting the Formation, Stability and Weathering of Common Soil Minerals. Soi1 Sci. Soc. Amer. Proc. 39:991-996.

Rai, Dhanpat and R. J. Serne. 1977. Plutonium Activities in Soil Solutions and the Stability and Formation of Selected Plutonium Minerals. J. Environ. Qua1., $\underline{6}: 89-95$.

Rai, Dhanpat, R. J. Serne, and D. A. Moore. 1977. Identification of Plutonium Compounds and Their Solubility in Soils, draft, PNL Report.

Rossini, F. D., D. D. Wagman, W. H. Evans, S. Levine and I. Jaffe. 1952. Selected Values of Chemical Thermodynamic Properties. NBS Circular 500, Washington, DC.

Schumm, R. H., D. D. Wagman, S. M. Bailey, W. H. Evans, and V. B. Parker. 1973. Selected Values of Chemical Thermodynamic Properties. Tables for the Lanthanide (Rare Earth) Elements (Elements 62 through 76) in the Standard Order of Arrangement. NBS Technical Note 270-7.

Sillen, L. G. and A. E. Marte11. 1964. Stability Constants of Metal-Ion Complexes. Special Publication No. 17. The Chemical Society, London. 
Tanji, K. K. and L. D. Doneen. 1966. A Computer Technique for Prediction of $\mathrm{CaCO}_{3}$ Precipitation in $\mathrm{HCO}_{3}^{-} \mathrm{Salt}$ Solution. Soil Sci. Soc. Amer. Proc. 30:53-55.

Wagman, D. D., W. H. Evans, V. B. Parker, I. Halow, S. M. Bailey, and R. H. Schumm. 1968. Selected Values of Chemical Thermodynamic Properties. Tables for the first 34 Elements in the Standard Order of Arrangement. NBS Technical Note 270-3.

Wagman, D. D., W. H. Evans, V. B. Parker, I. Halow, S. M. Bailey, and R. H. Schumm. 1969. Selected Values of Thermodynamic Properties. Tables for Elements 35 through 53 in the Standard Order of Arrangement. NBS Technical Note 270-4.

Wagman, D. D., W. H. Evans, V. B. Parker, I. Halow, S. M. Bailey, R. H. Schumm, and K. L. Churney. 1971. Selected Values of Chemical Thermodynamic Properties. Tables for Elements 54 through 61 in the Standard Order of Arrangement. NBS Technical Note 270-5.

\section{AMERICIUM}

Fried, S. 1977. The Retention of Plutonium and Americium by Rock.

Fried, S., A. M. Friedman, and L. A. Quarterman. 1974. Annual Report on Project AN0115A, Fiscal Year 1974. ANL-8115

Fried, S., A. M. Friedman, and R. Weeber. 1974. Studies of the Behavior of Plutonium and Americium in the Lithosphere. ANL-8096. pp. 10-11.

Glover, P. A., F. J. Miner, and W. L. Polzer. 1977. Plutonium and Americium Behavior in the Soil/Water Environment. I. Sorption of Plutonium and Americium by Soils. BNWL-2117.

Keller, C. 1971. The Chemistry of the Transuranium Elements. Vo1. 3, Kernchemie in Einzeldarstellungen. Verlag Chemie/GmbH.

Latimer, W. M. 1952. Oxidation Potentials. Second Edition. PrenticeHal1, Englewood Cliffs, NJ.

Routson, R. C., G. Jansen, and A. V. Robinson. 1975. Sorption of ${ }^{99} \mathrm{TC}, 237 \mathrm{~Np}$ and $241 \mathrm{Am}$ on Two Subsoils from Differing weathering Intensity Areas. BNWL-1889.

Sheppard, J. C., J. A. Kittrick, and T. L. Hart. 1976. Determination of Distribution Ratios and Diffusion Coefficients of Neptunium, Americium and Curium, in Soil-Aquatic Environments. RL0-2221-T-12-2.

Sillen, L. G. and A. E. Marte11. 1964. Stability Constants of MetalI on Complexes. Special Publication No. 17. The Chemical Society, London. 


\section{ANTIMONY}

Anonymous. 1973. 241-T-106 Tank Leak Investigation. ARH-2874.

Baes, C. F. and R. E. Mesmer. 1976. The Hydrolysis of Cations. John Wiley and Sons, New York.

Charlot, G. 1958. Selected Constants-0xidation Reduction Potentials of Inorganic Substances in Aqueous Solutions. Pergamon Press, New York.

Garrels, R. M. and C. L. Christ. 1965. Solutions, Minerals, and Equilibria. Harper and Row Publishers, New York.

Haney, W. A. and C. E. Linderoth. 1959. Exploratory Field Study of a Ground Waste Disposal Facility. HW-60115.

Haney, W. A. 1967. Final Report on the Effects of Ben Franklin Dam. BNWL-412.

Jackson, D. D. 1976. Radiochemical Studies for the Nuclear Chemical Mining of Copper. UCRL-52025.

Magno, P., T. Reavey, and J. Apidianakis. 1970. Liquid Waste Effluents from a Nuclear Fuel Reprocessing Plant. BRH-NERHL-70-2.

Saas, A. and A. Grauby. 1973. Mechanisms for the Transfer to Cultivated Soils of Radionuclides Discharged by Nuclear Power Stations into the System: River-Irrigated Soi1--Ground Water. In: Environmental Behavior of Radionuclides Released in the Nuclear Industry. IAEA-SM-172/57, pp. 255-269.

Sillen, L. G. and A. E. Martell. 1964. Stability Constants of MetalIon Complexes. The Chemical Society.

Wagman, D. D., W. H. Evans, V. B. Parker, I. Halow, S. M. Bailey, and R. H. Schumm. 1968. Selected Volumes of Chemical Thermodynamic Properties. U.S. Department of Commerce. NBS Technical Note 270-3.

\section{CERIUM}

Ahrens, L. H. 1952. The Use of Ionization Potentials. Part I. Ionic Radii of the Elements. Geochim, et Cosmochim. Acta. 2:155.

Anonymous. 1973. 241-T-106 Tank Leak Investigation. ARH-2874.

Baes, C. F., Jr. and R. E. Mesmer, 1976. The Hydrolysis of Cations. John Wiley and Sons, New York.

Bensen, D. W. 1960. Review of Soil Chemistry Research at Hanford. HW-67201. 
Brown, R. E., R. E. Franklin, and R. H. Miller. 1969. Reactions of Cerium-144 in Solution and Suspensions of Soil Humic Acid and

Bentonite. Soil Science Society of America, Proceedings. 33:677-681.

Eichholz, G. G., T. F. Craft, and A. N. Galli. 1967. Trace Element Fractionation by Suspended Matter in Water. Geochim. et Cosmochim.

Acta. $31: 737-745$.

Kampbe11, D. H. 1964. Cerium, Iron, and Manganese Sorption by Soil Colloids and Uptake by Plants. Thesis. Univ. of Missouri.

Kokotov, Yu. A., R. F. Popova, I. Tsing-Chih, and M. Shih-tsi. 1962. Sorption of Long Lived Fission Products by Soils and Argillaceous

Minerals. II. Sorption of Cerium-144 by Soils. Radiokhimya. 4:227-228.

Magno, P., T. Reavey, and J. Apidianakis. 1970. Liquid Waste Effluents from a Nuclear Fuel Reprocessing Plant. BRH-NERHL-70-2.

Nishita, H., B. W. Kowalewsky, A. J. Steen, and K. H. Larson. 1956. Fixation and Extractability of Fission Products Contaminating Various Soils and Clays: I. Strontium-90, Ruthenium-106, Cesium-137, and Cerium-144. Soil Science. 81:317-326.

Rhodes, P. W. 1957. The Effect of pH on the Uptake of Radioactive Isotopes from Solution by a Soil. Soil Science Society of America, Proceedings. $21: 389-392$.

Schumm, R. H., D. D. Wagman, S. M. Bailey, W. H. Evans, and V. B. Parker. 1973. Selected Values of Chemical Thermodynamic Properties. Tables for the Lanthanide (Rare Earth) Elements (Elements 62 through 76) in the Standard Order of Arrangement. NBS Technical Note 270-7.

Sillen, L. G. and A. E. Marte11. 1964. Stability Constants of Meta1ion Complexes. Special Publication No. 17. The Chemical Society, London.

\section{CESIUM}

Baes, C. F. and R. E. Mesmer. 1976. The Hydrolysis of Cations. John Wiley and Sons, New York.

Baetsle, L. H., P. Dejonghe, W. Maes, E. S. Simpson, J. Souffriau, and P. Staner. 1964. Underground Radionuclide Movement. EURAEC-703.

Berak, L. 1963. The Sorption of Microstrontium and Microcesium on the Silicate Minerals and Rocks. UJV-528-63.

Carlile, B. L. and B. F. Hajek. 1967. Soil Radionuclide Adsorption and Particulate Filtration in an N-Area Soi1. BNWL-CC-995. 
Charlot, G. 1958. Selected Constants-0xidation Reduction Potentials of Inorganic Substances in Aqueous Solutions. Pergamon Press, New York.

Coleman, N. T., R. J. Lewis, and D. Craig. 1963. Sorption of Cesium by Soils and its Displacement by Salt Solutions. Soil Science Society America, Proceedings. pp. 290-294.

Davis, J. J. 1961. Cesium and its Relationships to Potassium in Ecology. IN: Radioecology. V. Schultz and A. W. Klement (eds.). pp. $539-55 \overline{6}$.

Eichholz, G. G., T. F. Craft, and A. N. Galli. 1967. Trace Element Fractionation by Suspended Matter in Water. Geochim. et Cosmochim. Acta. $31: 737-745$.

Izrael, U. A., V. N. Petrov, A. A. Pressman, F. A. Rovinsky, E. D. Stukin, A. A. Ter-Saakov. 1969. Radioactive Contamination of the Environment by Underground Nuclear Explosions, and Methods of Forecasting it. Nordyke, M. (Technical Editor), Lawrence Radiation Laboratory, Livermore, CA.

Jacobs, D. G. 1962. Cesium Exchange Properties of Vermiculite. Nuclear Sci. Eng. 12:285-292.

Kno11, K. C. 1969. Reactions of Organic Wastes and Soils. BNWL-860.

Levi, H. W. and N. Miekeley. 1967. Studies on Ion Diffusion in Vermiculite. IN: Disposal of Radioactive Wastes into the Ground. IAEASM-93/12, pp. 161-167.

Lomenick, T. F., D. G. Jacobs and E. G. Struxness. 1967. The Behavior of Strontium-90 and Cesium-137 in Seepage Pits at ORNL. Health Physics. 13:897-905.

Magno, P., T. Reavey, and J. Apidianakis. 1970. Liquid Waste Effluents from a Nuclear Fuel Reprocessing Plant. BRH-NERHL-70-2.

Mawson, C. A. 1956. Waste Disposal into the Ground. Proc. of the Inter. Conf. on the Peaceful Uses of Atomic Energy. 9:676-678.

McHenry, J. R. 1954. Adsorption and Retention of Cesium by Soils of the Hanford Project. HW-31011.

Nishita, H. and E. H. Essington. 1967. Effect of Chelating Agents on the Movement of Fission Products in Soils. Soil Science. 102:168-176.

Prout, W. E. 1958. Adsorption of Radioactive Wastes by Savannah River Plant Soil. Soil Science. 86:13-17. 
Routson, R. C. 1973. A Review of Studies on Soil-Waste Relationships on the Hanford Reservation from 1944 to 1967 . BNWL-1464.

Salo, A. and R. Saxen. 1974. On the Role of Humic Substances in the Transport of Radionuclides. Report SFL-A20, Inst. Rad. Phy., Helsinki, Finland.

Tamura, T. 1963a. Cesium Sorption Reactions as Indicator of Clay Mineral Structures. IN: Proc. Nat1. Conf. Clays, Clay Minerals. 10:389-398.

Tamura, T. 1963b. Selective Ion Exchange Reactions for Cesium and Strontium by Soil Minerals. Colog. Intern. Retention Migration Ions Radioactifs Sols, Saclay, p. 95-104.

Tamura, T. and D. G. Jacobs. 1960. Structural Implications in Cesium Sorption. Health Physics. 2:391-398.

Tamura, T. and D. G. Jacobs. 1961. Improving Cesium Selectivity of Bentonites by Heat Treatment. Health Physics. 5:149-154.

\section{COBALT}

Baes, C. F., Jr. and R. E. Mesmer. 1976. The Hydrolysis of Cations. John Wiley and Sons, New York.

Basu, A. N. and S. K. Mukherjee. 1965. Interaction Between Montmorillonite Clay and Trace Element Cations. II. Exchange Behavior of Cobalt, Nickel and Chromium Ions in Clays. J. Indian Soc. Soil Sci. $13: 251-256$.

Chase, M. W., J. L. Curnutt, H. Prophet, R. A. McDonald and A. N. Syverud. 1975. JANAF Thermochemical Tables, 1975 Supplement. Journ. Phys. and Chem. Ref. Data 1974. (1)4.

Duguid, J. 0. 1976. Annual Progress Report of Burial Ground Studies at Oak Ridge National Laboratory: Period Ending September 30, 1975. ORNL-5141.

Dunigan, E. P. and C. W. Francis. 1972. Adsorption and Desorption of Cobalt 60, Strontium 85, and Cesium 137 on Soil Humic Acid. Soil Science. 114:494-496.

Friend, A. G. 1963. The Aqueous Behavior of $85 \mathrm{sr}, 137 \mathrm{cs}, 65 \mathrm{Zn}$, and 60Co as Determined by Laboratory Type Studies. IN: Transport of Radionuclides in Fresh Water Systems. TID-7664.

Gonzalez, G. F. and A. M. Gomez. 1961. Geochemistry of Cobalt in Soils of Western Andalusia. IV. Cobalt Clays and Correlation Between Cobalt and Iron, Clay and Manganese Contents. An. Edafol. Agroboil. 23:563-572. 
Haney, W. A. 1967. Final Report on the Effects of Ben Franklin Dam on Hanford. BNWL-412, pp. 8-13.

Hawkins, D. B. 1964. Removal of Cobalt and Chromium by Precipitation and Ion Exchange on Soil, Lignite and Clinoptilolite from CitrateContaining Radioactive Liquid Waste. ID0-12036.

James, R. 0. and T. W. Healy. 1972. Adsorption of Hydrolyzable Metal Ions at the 0xide-Water Interface. J. Colloid Interfac. Sci. 40:65-8?.

Means, J. L., D. A. Crerar, and J. 0. Duguid. 1976. Chemical Mechanisms of 60Co Transport in Ground Water from Intermediate - Level Liquid Waste Trench 7: Progress Report for Period Ending June 30, 1975. ORNL/TM-5348.

Rhodes, D. W. and J. L. Nelson. 1957. Disposal of Radioactive Liquid Wastes from the Uranium Recovery Plant. HW-54721.

Robie, R. A. and D. R. Waldbaum. 1968. Thermodynamic Properties of Minerals and Related Substances at $298.15^{\circ} \mathrm{K}\left(25^{\circ} \mathrm{C}\right)$ and One Atmosphere (1.013 bars) Pressure and at Higher Temperatures. Geol. Surv. Bu11. 1259.

Saas, A. and A. Grauby. 1973. Mechanisms for the Transfer to Cultivated Soils of Radionuclides Discharged by Nuclear Power Stations into the System: River-Irrigated Soil-Ground Water. IN: Environmental Behavior of Radionuclides Released in the Nuclear Industry. IAEA-SM-172/57, pp. 255-269.

Sillen, L. G. and A. E. Marte11. 1964. Stability Constants of Meta1Ion Complexes. Special Publication No. 17. The Chemical Society, London.

Sorathesn, A. G. Bruscia, T. Tamura, and E. G. Struxness. 1960. Minera1 and Sediment Affinity for Radionuclides. CF-60-6-93.

Tewari, P. H., A. B. Campbe11, and W. Lee. 1972. Adsorption of Cobalt $(+2)$ by Oxides from Aqueous Solution. Can. J. Chem. 50:1642-1648.

Wagman, D. D., W. H. Evans, V. B. Parker, I. Halow, S. M. Bailey, and R. H. Schumm. 1968. Selected Values of Chemical Thermodynamic Properties. Tables for the First Thirty-Four Elements in the Standard Order of Arrangement. NBS Technical Note 270-3.

Wagman, D. D., W. H. Evans, V. B. Parkers, I. Halow, S. M. Bailey and R. H. Schumm. 1969. Selected Values of Thermodynamic Properties. Tables for Elements 35 through 53 in the Standard Order of Arrangement. NBS Technical Note 270-4.

Wilding, M. W. and D. W. Rhodes. 1963. Removal of Radioisotopes from Solution by Earth Materials from Eastern Idaho. ID0-14624. 
Jacobs, D. G., Y. E. Kim, and 0. M. Sealand. 1966. Application of Mineral Exchange to Reactor Technology. ORNL-4007, pp. 27-33.

Jones, A. D. and G. R. Choppin. 1969. Complexes of Actinide Ions in Aqueous Solutions, Actinide Reviews. 1:311-336.

Keller, C. 1971. The Chemistry of the Transuranium Elements. Vo1. 3. Kernchemie in Einzeldarstellungen. Verlag Chemie GmbH.

Moskin, A. I. 1969. Complex Formation of the Actinides with Anions of Acides in Aqueous Solutions. Soviet Radiochemistry. 11:447.

Nugent, L. J. 1975. Chemical Oxidation States of the Lanthanides and Actinides. IN: Bagnal1, K. W. (ed.). Lanthanides and Actinides, Internationa 1 Review of Science, Inorganic Chemistry Series, Volume 7. University Park Press, Baltimore, Maryland. pp. 195-219.

Shal inets, A. B. and A. V. Stepanov. 1972. Investigation of Complex Formation of the Trivalent Actinide and Lanthanide Elements by the Method of Electromigration. XVII. Hydrolysis. Radiokhimiya. 14:280-282.

Sheppard, J. C., J. A. Kittrick, and T. L. Hart. 1967. Determination of Distribution Ratios and Diffusion Coefficients of Neptunium, Americium and Curium in Soi1-Aquatic Environments. RL0-2221-T-12-2.

Thomas, W. A. and D. G. Jacobs. 1969. Curium Behavior in Plants and Soil. Soil Science. 108:305-307.

Trotman-Dickinson, A. F. (Executive Ed.). 1973. Comprehensive Inorganic Chemistry. Pergamon Press, New York.

Vickery, R. C. 1953. Chemistry of the Lanthanons. Butterworths Sci. Publ., London.

\section{EUROPIUM}

Baes, C. F., Jr. and R. E. Mesmer. 1976. The Hydrolys is of Cations. John Wiley and Sons, New York.

Baetsle, L. and P. Dejonghe. 1962. Investigations on the Movement of Radioactive Substances in the Ground. Part III: Practical Aspects of the Program and Physiocochemical Considerations. IN: Ground Disposal of Radioactive Wastes. TID-7628, pp. 198-210.

Bensen, D. W. 1960. Review of Soil Chemistry Research at Hanford. $\mathrm{HW}-67201$. 
Latimer, W. M. 1952. The Oxidation States of the Elements and Their Potentials in Aqueous Solutions. Prentice-Hall, Inc.

Schumm, R. H., D. D. Wagman, S. M. Bailey, W. H. Evans, and V. B. Parker. 1973. Selected Values of Chemical Thermodynamic Properties. Tables for the Lanthanide (Rare Earth) Elements (Elements 62 through 76) in the Standard Order of Arrangement. NBS Technical Note 270-7. Schwille, F., W. Lippok and D. Weisflog. 1967. Model Experiments on Fluid Flow in the Transition Zone from Unsaturated to Saturated Soi1. IAEA-SM-93/11, pp. 151-159.

Walker, J. B., G. R. Choppin. 1967. Thermodynamic Parameters of Fluoride Complexes of the Lanthanides. Advances in Chemistry Series No. 71. The American Chemical Society, Washington D.C. pp. 127-140.

\section{IODINE}

Irinevich, A. D., I. Z. Rabinovich, and V. A. Fil'Kov. 1970. Iodine in Moldavian Soils. Pochvovedenie. 58.

Pennington, W. and J. P. Lishman. 1971. Iodine in Lake Sediments in Northern England and Scotland. Biol. Rev. 46:279-313.

Pourbaix, M. 1966. Atlas of Electrochemical Equilibria in Aqueous Solutions. Pergamon Press, Oxford, England.

Sinitskaya, G. I. 1969. Iodine Content of the Zeya-Bureya Plain Soils. Uch. Zap. Dal'nevost. Gos. Univ. 27:72.

Walters, L. J. and J. W. Winchester. 1971. Neutron Activation Analysis of Sediments for Halogens Using Szilard-Chalmers Reactions. Anal. Chem. 43:1020.

Wildung, R. E., R. C. Routson, R. J. Serne, and T. R. Garland. 1975. Pertechnetate, Iodide and Methyl Iodide Retention by Surface Soils. BNWL-1950. Pt. 2. pp. 37-40.

\section{NEPTUNIUM}

Burney, G. A. and R. M. Harbour. 1974. Radiochemistry of Neptunium. NAS-NRC Nuclear Sci. Ser. NAS-NA-3060.

Keller, C. 1971. The Chemistry of the Transuranium Elements. Vo1. 3. Kernchemie in Einzeldarstellungen. Verlag Chemie GmbH.

Routson, R. C., G. Jansen, and A. V. Robinson. 1975. Sorption of 99TC, $237 \mathrm{~Np}$, and $241 \mathrm{Am}$ on Two Subsoils from Differing Weathering Intensity Areas. BNWL-1889. 
Routson, R. C., G. Jansen, and A. V. Robinson. 1976. 99Tc, 237Np, and 241Am Sorption on Two Subsoils from Differing Weathering Intensity Areas. BNWL-2000. Pt. 2, pp. 50-52.

Sillen, L. G. and A. E. Marte11. 1964. Stability Constants of Metal-Ion Complexes. Special Publication No. 17. The Chemical Society, London.

Sheppard, J. C., J. A. Kittrick, T. L. Hart. 1976. Determination of Distribution Ratios and Diffusion Coefficients of Neptunium, Americium and Curium in Soi1-Aquatic Environments. RL0-221-T-12-2.

\section{PLUTONIUM}

Andelman, J. B. and T. C. Rozze11. 1970. Plutonium in the Water Environment. I. Characteristics of Aqueous Plutonium. IN: Radionuclides in the Environment. Adv. in Chem. Ser. No. 93. Amer. Chem. Soc., Washington D.C., pp. 118-137.

An, F. H. F. 1964. The Role of Soil Microorganisms in the Movement of Plutonium. IN: Dunaway, P. B. and M. G. White (ed.). The dynamics of plutonium in desert environments. NV0-142, pp. 135-141.

Bensen, D. W. 1960. Review of Soil Chemistry Research at Hanford. $H W-67201$.

Bondietti, E. A. 1974. Adsorption of Pu(IV) and Th(IV) by Soil Colloids. Agronomy Abstracts.

Casso1, A., L. Magon, R. Portanova, and E. Tontde110. 1972. Hydrolysis of Plutonium (IV): Acidity Measurements in Perchloric Solutions.

Radiochim. Acta 17:28-32.

Cleveland, J. M. 1970. The Chemistry of Plutonium. Gordon and Breach Science Publishers.

Desai, M. V. M. and A. K. Ganguly. 1970. Interaction of Trace Elements with Organic Constituents in the Marine Environment. BARC-488.

Emery, R. M., D. C. Klopfer and W. C. Weimer. 1974a. Ecological Behavior of Plutonium and Americium in a Fresh Water Ecosystem. Phase I. Limnological Characterization of Isotopic Distribution. BNWL-1867.

Emery, R. M. and T. R. Garland. 1974b. The Ecological Behavior of Plutonium and Americium in a Fresh Water Ecosystem: Phase II. Implications of Differences in Transuranic Isotopic Ratios. BNWL-1879.

Emery, R. M., D. C. Klopfer, T. R. Garland and W. C. Weimer. 1975. Ecological Behavior of Plutonium and Americium in a Freshwater Pond. BNWL-SA-5346. 
Evans, E. J. 1956. Plutonium Retention in Chalk River Soil. CRHP-660.

Friedman, A. M., S. Fried, J. Hines, and L. Quaterman. 1977. Migration of $\mathrm{Pu}$ and Am. BNWL-2117, pp. 73-102.

Fukai, R. and C. N. Murray. 1974. Adsorption and Desorption of Plutonium and Americium in Freshwater - Sediment and Seawater - Sediment Systems. IN: Activities of the International Laboratory of Marine Radioactivity. IAEA-163, pp. 96-103.

Glover, P. A., F. J. Miner, and W. L. Polzer. 1977. Plutonium and Americium Behavior in the Soil/Water Environment. I. Sorption of Plutonium and Americium by Soils. BNWL-2117.

Grebenshchikova, V. I. and Y. P. Davydov. 1961. A Study of the State of Pu(IV) in Dilute Solutions of Nitric Acid. Radiokhimiya. 3:155-164.

Grebenshchikova, V. I. and Y. P. Davydov. 1965. State of Pu(IV) in the Region of $\mathrm{pH}$ 1.0-12.0 at a Plutonium Concentration of $2.0 \times 10-5 \mathrm{M}$. Radiokhimiya. 7:191-195.

Hajek, B. F. and K. C. Knoll. 1966. Disposal Characteristics of Plutonium and Americium in a High Salt Acid Waste. BNWL-CC-649.

Keller, C. 1971. The Chemistry of the Transuranium Elements. Vol. 3. Kernchemie in Einzeldarstellungen. Verlag Chemie GmbH.

Knoll, K. C. 1965. Reaction of High Salt Aqueous Plus Organic Waste with Soil. BNWL-CC-313.

Kno11, K. C. 1969. Reactions of Organic Wastes in Soils. BNWL-860.

Magno, P., T. Reavey, and J. Apidiunakis. 1970. Liquid Was te Effluents from a Nuclear Fuel Processing Plant. BRH/NERHL-70-2.

Meyer, G. L. 1975. Preliminary data on the occurrence of transuranium nuclides in the environment at the radioactive waste burial sites, Maxey Flats, Ky. IAEA-SM-199/105.

Mo, T. and F. G. Lowman. 1975. Laboratory Experiments on the Transfer Dynamics of Plutonium from Marine Sediments to Seawater and to Marine Organisms. CONF-750503-5.

Montgomery, D. M., H. E. Kolde, and R. L. Blanchard. 1977. Radiological Measurements at the Maxey Flats Radioactive Waste Burial Site. 1974-1975. EPA-520/5-76/020.

Polzer, W. L. 1971. Solubility of Plutonium in Soi1/Water Environments. CONF-710401, pp. 411-430. 
Polzer, W. L. and F. J. Miner. 1977. Plutonium and Americium Behavior in the Soil/Water Environment. II. The Effect of Selected Chemical and Physical Characteristics of Aqueous Plutonium and Americium on Their Sorption by Soils. BNWL-2117.

Price, S. M. and L. L. Ames. 1975. Characterization of Actinide-Bearing Sediments Underlying Liquid Waste Disposal Facilities at Hanford. IAEA-SM$199 / 87$.

Prout, W. E. 1958. Adsorption of Radioactive Wastes by Savannah River Plant Soil. Soil Science. 86:13-17.

Prout, W. E. 1959. Adsorption of Fission Products by Savannah River Plant Soil. DP-394.

Rai, Dhanpat and R. J. Serne. 1977. Plutonium Activities in Soil Solutions and the Stability and Formation of Selected Plutonium Metals. Journal Environmental Quality. 6:89-95.

Rhodes, D. W. 1952. Preliminary Studies of Plutonium Adsorption in Hanford Soil. HW-24548.

Rhodes, D. W. 1957a. The Adsorption of Plutonium by Soil. Soil Science. $84: 465-471$.

Rhodes, D. W. 1957b. The Effect of pH on the Uptake of Radioactive Isotopes from Solution by a Soil. Soil Science Society of America, Proceedings. 21:389-392.

Sheidina, L. D. and E. N. Kovarskaya. 1970. Colloidal State of Pu(IV) in Aqueous Solutions. Sov. Radio. Chem. 12:229-233.

Sillen, L. G., and A. E. Martel1. 1964. Stability Constants of Metal Ion Complexes. 2nd ed. Spec. Publ. No. 17. The Chem. Soc., London.

Tamura, T. 1974. Distribution and Characterization of Plutonium in Soils from Nevada Test Site. p. 24-42. IN: P. B. Dunaway and M. G. White (ed.) The Dynamics of Plutonium in Desert Environments. NVO-142.

Thorburn, R. C. 1950. Absorption on Hanford Soil and Related Soil Properties. HW-15655.

Van Dalen, A., F. Dewitte, and J. Wiskstra. 1975. Distribution Coefficients for Some Radionuclides Between Saline Water and Clays, Sandstones and Other Samples from the Dutch Subsoil. Reactor Centrum Nederland. pp. 75-109.

Wildung, R. E. and T. R. Garland. 1973. Influence of Soil Microbial Activity on the Uptake and Distribution of Plutonium in the Shoots and Roots of Barley. BNWL-1850, Pt. 2, pp. 22-25. 
Wildung, R. E. and T. R. Garland. 1977. The Relationship of Microbial processes to the fate and behavior of transuranic elements in soils and plants. IN: The Transuranium Elements in the Environment.

W. C. Hanson (ed.).

\section{PROMETHIUM}

Ames, L. L., Jr. 1960. Some Cation Substitutions During the Formation of Phosphorite from Calcite, Economic Geology. 55:354-362.

Bensen, D. W. 1960. Review of Soil Chemistry Research at Hanford. HW- 67201 .

Lavrukhina, A. K. and A. A. Pozdnyakov. 1970. Analytical Chemistry of Technetium, Promethium, Astatine and Francium. Translated by R. Kondor. Ann Arbor - Humphrey Science Publishers.

Magno, P., T. Reavey, and J. Apidianakis. 1970. Liquid Waste Effluents from a Nuclear Fuel Reprocessing Plant. BRH-NERHL-70-2.

Pourbaix, M. 1966. Atlas of Electrochemical Equilibria in Aqueous Solutions. Pergamon Press, Oxford, England.

Schultz, R. K. 1965. Soil Chemistry of Radionuclides. Health Physics. $11: 1317-1324$.

Sillen, L. G. and A. E. Marte11. 1964. Stability Constants of Metal-Ion Complexes. Special Publication No. 17. The Chemical Society, London.

Starik, I. E., N. I. Ampelogova, F. L. Ginzburg, M. S. Lambert, I. A. Skulskii, and V. N. Shchebetkovskii. 1959. On the Molecular State of U1tra-Sma11 Quantities of Radioelements in Solutions. Radiokhimiya. 1:370-378 (in Russian).

\section{$\underline{\text { RADIUM }}$}

Arnold, W. D. and D. J. Crouse. 1965. Radium Removal from Uranium Mill Effluents with Inorganic Ion Exchangers. I\&EC Process Design and Development. $4: 335-337$.

Granger, H. C. 1963. Radium Migration and Its Effect on the Apparent Age of Uranium Deposits at Ambrosia Lake, New Mexico. Us. Geol. Survey Prof. Paper 475-B, pp. B-60-B-63.

Granger, H. C., E. S. Santos, B. G. Dean and F. B. Moore. 1961. Sandstone-Type Uranium Deposits at Ambrosia Lake, New Mexico - an Interim Report. Econ. Geol., vol. 56, no. 7, pp 1179-1209. 
Havlik, B., B. Nycova, and J. Grafova. 1968. Radium-226 Liberation from Uranium Ore Processing Mill Waste Solids and Uranium Rocks into Surface Streams - II. Health Physics. 14:423-430.

Parker, V. B., D. D. Wagman, and W. H. Evans. 1971. Selected Values of Chemical Thermodynamic Properties. U.S. Department of Commerce. NBS Technical Note 270-6.

Schubert, A. J., E. R. Russe11, and L. S. Myers. 1950. Dissociation Constants of Radium Inorganic Acid Complexes Measured by Ion Exchange. J. Biol. Chem. 185:387-398.

Shearer, S. D., Jr. 1962. The Leachability of Radium-226 from Uranium Mill Solids and River Sediments. Thesis. Univ. Wisconsin.

Shearer, S. D., Jr. and G. F. Lee. 1964. Leachability of Radium-226 from Uranium Mill Solids and River Sediments. Health Physics. 10:217-227.

Starik, I. E. and K. F. Lazarev. 1960. Effect of Crushing of Minerals on the Extraction of Radioactive Elements. Radiokhimiya. II:749-752.

Starik, I. E. and N. I. Polevaya. 1958. The Leachability of ThX and Rd Th from Minerals. AEC-tr-4208, pp. 108.

\section{RUTHENIUM}

Amy, J. P. 1971. Contribution to the Study of the Migration of Ruthenium-106 in Soils.

Anonymous. 1973. 241-T-106 Tank Leak Investigation. ARH-2874.

Baes, C. F., Jr. and R. F. Mesmer. 1976. The Hydrolysis of Cations. John Wiley and Sons, New York.

Brown, D. J. 1967. Migration Characteristics of Radionuclides Through Sediments Underlying the Hanford Reservation. ISO-SA-32.

Brown, D. J. and W. A. Haney. 1964. Chemical Effluents Technology Waste Disposal Investigations July-December, 1973 - The Movement of Contaminated Ground Water from the 200 Areas to the Columbia River. HW-80909.

Champlin, J. B. F. and G. G. Eichholz. 1968. The Movement of Radioactive Sodium and Ruthenium Through a Simulated Aquifer. Water Resources Research. 4:147-158.

Eichholz, G. G., T. F. Craft, and A. N. Galli. 1967. Trace Element Fractionation by Suspended Matter in Water. Geochim. et Cosmochim. Acta. 31:737-745. 
Haney, W. A., D. J. Brown, and A. E. Reisenauer. 1962. Fission Product Tritium in Separations Wastes and in the Ground-Water. HW-74536.

Izrael, Yu. A. and F. Ya. Rovinskii. 1970. Hydrological Uses of Isotopes Produced in Underground Nuclear Explosions for Peaceful Purposes. UCRLTrans-10458.

Kepak, F. 1966. Sorption of the Radioisotopes ${ }^{35} \mathrm{~S},{ }^{131} \mathrm{I}$ and ${ }^{106} \mathrm{Ru}$ on Hydrated Oxides in Laboratory Columns. Collection Czechoslov. Chem. Commun. $31: 3500-3511$.

Magno, P., T. Reavey, and J. Apidianakis. 1970. Liquid Waste Effluents from a Nuclear Fuel Reprocessing Plant. BRH-NERHL-70-2.

Pickering, R. J., P. H. Carrigan, T. Tamura, H. H. Abee, J. W. Beverage, and R. W. Andrew. 1966. Radioactivity in Bottom Sediments of the Clinch - Tennessee Rivers. IAEA-SM-72/4.

Pourbaix, M. 1966. Atlas of electrochemical equilibria in aqueous solution. Pergamon Press, Oxford, England.

Raymond, J. R. 1964. Investigation of the Disposition and Migration of Gross Gamma Emitters Beneath Liquid Waste Disposal Sites. HW-81746, pp. $4.32-4.36$.

Raymond, J. R. 1965. Cesium and Strontium Distribution Beneath Liquid Waste Disposal Sites. BNWL-235.

Rhodes, D. W. 1957. The Effect of pH on the Uptake of Radioactive Isotopes from Solution by a Soil. Soil Science Society of America, Proceedings. 21:389-392.

Schulz, R. K. 1965. Soil Chemistry of Radionuclides. Health Physics. $11: 1317-1324$.

Sillen, L. G. and A. E. Marte11. 1964. Stability Constants of MetalIon Complexes. Special Publication No. 17. The Chemical Society, London.

Spitsyn, V. I., V. D. Balukova, A. F. Naumova, V. V. Gromov, F. M. Spiridonov, E. M. Vetrov, and G. I. Gravfov. 1958. A Study of the Migration of Radioelements in Soils. IN: Proc. Second Annual U.N. Conf. Peaceful Uses of Atomic Energy. 18:439-448.

Trotman-Dickinson, A. F. (Executive Ed.). 1973. Comprehensive inorganic chemistry. Pergamon Press, New York.

Wagman, D. D., W. H. Evans, V. B. Parker, I. Halow, S. M. Bailey and R. H. Schumm. 1969. Selected Values of Chemical Thermodynamic Properties. Tables for Elements 35 through 53 in the Standard Order of Arrangement Nat. Bur. Stds. Technical Note 270-4. 


\section{STRONTIUM}

Ames, L. L., Jr., J. R. McHenry, and J. F. Honstead. 1958. The Removal of Strontium from Wastes by a Calcite - Phosphate Mechanism. IN: Proc. 2nd UN Int. Conf. PUAE. 18:76.

Baetsle, L. H., P. Dejonghe, W. Maes, E. S. Simpson, J. Souffriau, and P. Staner. 1964. Underground Radionuclide Movement. EURAEC-703.

Baker, J. H. and W. A. Beetem. 1961. Distribution Coefficients for Adsorption of Carrier-Free Cesium, Strontium, and Iodine by Sample from the Vicinity of Cape Thompson, NW Alaska, U.S.G.S. Tech Letter Chariot-1.

Berak, L. 1963. The Sorption of Microstrontium and Microcesium on the Silicate Minerals and Rocks. UJV-528-63.

Carlile, B. L. and B. F. Hajek. 1967. Soil Radionuclide Adsorption and Particulate Filtration in an N-Area Soil. BNWL-CC-995.

Chase, M. W., J. L. Curnutt, H. Prophet, R. A. McDonald, and A. N. Syverud. 1975. JANAF Thermochemical Tables, 1975 Supplement. J. Phys. and Chem. Ref. Data 1974. (1) 4.

Helgeson, H. C. 1969. Thermodynamics of Hydrothermal Systems at Elevated Temperature and Pressures. American Journal of Science. $267: 729-804$.

Himes, F. L. and R. Shufeldt. 1970. Influence of Some Organic Compounds on the Movement of Sr90 in Soils. CO0-414-11.

Jenne, E. A. and J. S. Wahlberg. 1968. Role of Certain Stream - Sediment Components in Radioion Sorption. U.S.G.S. Professional Paper 433-F.

Juo, A. S. R. and S. A. Barber. 1970. The Retention of Strontium by Soils as Influenced by $\mathrm{pH}$, Organic Matter and Saturated Cations. Soil Science. 109:143-148.

Klechkovsky, V. M., L. N. Sokdova, and G. N. Tselishcheva. 1958. Sorption of Microquantities of Strontium and Cesium in Soil. IN: Proc. UN Inter. Conf. Peaceful Uses of Atomic Energy, 2nd, Geneva, September 1-13, 1958. 18:486-493.

Kokotov, Yu. A. and R. F. Popova. 1962. Sorption of Long-Lived Fission Products by Soils and Argillaceous Minerals III: Selectivity of Soils and Clays Toward 90Sr Under Various Conditions. Sov. Radiochem. $4: 292-297$.

Kokotov, Yu. A., R. F. Popova, and A. P. Urbany. 1961. Sorption of Long-Lived Fission Products on Soils and Clay Minerals. Radiokhimya. 3:199-206. 
Magno, P., T. Reavey, and J. Apidianakis. 1970. Liquid Waste Effluents from a Nuclear Fuel Reprocessing Plant. BRH-NERHL-70-2.

McHenry, J. R. 1955. Adsorption and Retention of Strontium by Soils of the Hanford Project. HW-34499.

McHenry, J. R. 1958. Ion Exchange Properties of Strontium in a Calcareous Soi1. Soil Science Society America, Proceedings. 22:514-518.

Mortensen, J. L. and E. C. Marcusiu. 1963. Fission Product-Soil Organic Matter Complexes: I. Strontium-90 (Yttrium-90) in Water Extracts and HCl Hyarolysates of Soil. Soil Sci. Soc. Amer. Proc. 27:653-656.

Parker, V. B., D. D. Wagman, and W. H. Evans. 1971. Selected Values of Chemical Thermodynamic Properties. Tables for the Alkaline Earth Elements (Elements 92 through 97) in the Standard Order of Arrangement. NBS Technical Note 270-6.

Parsons, P. J. 1963. Migration from a Disposal of Radioactive Liquid in Sands. Health Physics. 9:333-342.

Prout, W. E. 1958. Adsorption of Radioactive Wastes by Savannah River Plant Soil. Soil Science. 86:13-17.

Prout, W. E. 1959. Adsorption of Fission Products by Savannah River Plànt Soil. DP-394.

Rhodes, D. W. and J. L. Nelson. 1957. Disposal of Radioactive Liquid Wastes from the Uranium Recovery Plant. HW-54721.

Schulz, R. K. 1965. Soil Chemistry of Radionuclides. Health Physics. $11: 1317-1324$.

Sillen, L. G. and A. E. Marte11. 1964. Stability Constants of Metal-Ion Complexes. Special Publication No. 17. The Chemical Society, London.

Spitsyn, V. I., V. D. Balukova, V. V. Gromov, S. I. Zakharov, B. P. Zhagin and F. M. Spiridonov. 1960. Sorption Regularities in Behavior of Fission-Product Elements During Filtration of Their Solutions Through Ground. IN: Disposal of Radioactive wastes. Il:429-435.

Varga, J. A. and D. G. Jacobs. 1970. Dissolution of Calcium-Strontium Carbonate and Its Subsequent Movement in the Ground. ORNL-TM-3130.

Wagman, D. D., W. H. Evans, V. B. Parker, I. Halow, S. M. Bailey, and R. H. Schumm. 1968. Selected volumes of Chemical Thermodynamic Properties. U.S. Department of Commerce. NBS Technical Note 270-3. 


\section{TECHNETIUM}

Anders, E. 1960. The Radiochemistry of Technetium. Nuclear Sci. Ser. Nat. Acad. Sci. - Nat. Res. Counci1. NAS-NS 3021.

Boyd, G. E. 1959. Technetium and Promethium. J. Chem. Educ. 36:3-14. Gast, R. G. 1975. The Behavior of Technetium-99 in Soils and Plants. Progress Report. COO-2447-1.

Kotegov, K. V., O. N. Pavlov and V. P. Shvedov. 1968. Technetium. IN: Advances in Inorganic Chemistry and Radiochemistry, Vol. 11, pp. 1-90, Academic Press, NY.

Routson, R. C., G. Jansen and A. V. Robinson. 1976. ${ }^{99} \mathrm{Tc},{ }^{237} \mathrm{~Np}$, and 241 Am Sorption on Two Subsoils from Differing Weathering Intensity Areas. BNWL-2000. Pt. 2, pp. 50-52.

Routscn, R. C., G. Jansen, and A. V. Robinson. 1977. ${ }^{241} \mathrm{Am},{ }^{237} \mathrm{~Np}$, and ${ }^{99}$ Tc Sorption on Two United States Subsoils from Differing Weathering Intensity Areas. BNWL-1889.

Wildung, R. E., R. C. Routson, R. J. Serne, and T. R. Garland. 1975. Pertechnetate, Iodide and Methyl Iodide Retention by Surface Soils. BNWL-1950. Pt. 2, pp. 37-40.

\section{$\underline{\text { THORIUM }}$}

Baes, C. F., Jr. and R. F. Mesmer. 1976. The Hydrolysis of Cations. John Wiley and Sons, New York.

Baranov, V. I., A. B. Ronov, and K. G. Kinashova. 1956. On Geochemistry of Dispersed Thorium and Uranium in Clays and Carbonate Rocks of Russian Platform. Geokhimiya No. 3:3-8.

Bondietti, E. A. 1974. Adsorption of Pu(IV) and Th(IV) by Soil Colloids. Agronomy Abstracts.

Desai, M. V. M. and A. K. Ganguly. 1970. Interaction of Trace Elements with Organic Constituents in the Marine Environment. BARC-488, p. 102.

Hansen, R. 0. 1970. Radioactivity of a California Terrace Soi1. Soil Science. 110:31-36.

Hansen, R. 0. and G. L. Huntington. 1969. Thorium Movements in Morainal Soils of the High Sierra, California. Soil Science. 108:257-265.

Keller, C. 1971. The chemistry of Transuranium elements. Vol. 3. Kernchemie in Einzeldarstellungen. Verlag Chemie GmbH. 
Kimura, Y., H. Morishuma, T. Koga, H. Kawai and Y. Honda. 1968. Studies on the Behavior and Distribution of Radioactive Substances in Coastal and Estuarine Waters. Kinki Daigaku Genshiryaku Kenkyusho Nonpo. 7:21-31 (in Japanese).

Kuznetsov, Y. V., Z. N. Simonyak, A. P. Lisitsyn, and M. S. Frenklikh. 1968. Thorium Isotopes (230Th, 232Th) in the Surface Layer of the Indian Ocean Sediments. Geochem, Int. 5:169-77.

Lazarev, K. F., D. S. Nikolaev, and S. M. Grashchenko. 1961. Concentration of Thorium Isotopes in Sea Water. Radiokhimiya. 3:623-35 (in Russian).

Menze1, R. G. 1968. Uranium, Radium, and Thorium Content in Phosphate Rocks and Their Possible Radiation Hazard. J. Agr. Food Chem. 16:231-34.

Nishiwaki, Y., Y. Honda, Y. Kimura, H. Morishima, T. Koga, Y. Miyaguchi, and H. Kawai. 1972. Behavior and Distribution of Radioactive Substances in Coastal and Estuarine Waters. IN: Radioactive Contamination of the Marine Enviroment. IAEA-SM-158/11, pp. 177-193.

Pashneva, G. E., T. P. Slavnina, and V. V. Serebrennikov. 1965. Rare Earth and Thorium Content in Soils of Tomsk Region. Izv. Sibirsk. Otd. Akad. Nauk SSR, No. 4 Ser. Boil.-Med. Nauk. No. 1:48-52 (in Russian).

Pokidin, V. K., Y. V. Kuznetov, E. A. Prozorovich, and F. A. Asadullaeva. 1972. Radioactivity and Rate of Sediment Formation in the Caspian Sea. Geokhimiya. No. 7:834-43 (in Russian).

Rancon, D. 1973. The Behavior in Underground Environments of Uranium and Thorium Discharged by the Nuclear Industry. IN: Environmental Behavior of Radionuclides Released in the Nuclear Industry. IAES-SM172/55, pp. 333-346 (in French).

Rubtsov, D. M. 1972. Thorium and Radium Content in the Silt Fraction of the Podzolic Mountain Soils of Thin Forests. Radioekologicheskie Issledavaniya Prirodnykh Biogeotsenozakh. IN: Verkhovskaya (ed.) Izdatel'stov Nauka, pp. 42-53.

Schulz, R. K. 1965. Soil Chemistry of Radionuclides. Health Physics. $11: 1317-24$.

Sillen, L. G. and A. E. Marte11. 1964. Stability Constants of Metal-Ion Complexes. Special Publication No. 17. The Chemical Society, London.

Tyuryukanova, E. B. and V. A. Kalugina. 1971. The Behavior of Thorium in Soils. Soviet Journal of Ecology. 2:467-469.

Yakobenchuk, V. F. 1968. Radioactivity and Chemical Properties of Sod-Podzolic Soils in the Ukrainian Western Polesie. Visn. Sil's'Kogosped. Nauki. 11:45-50 (in Ukranian). 


\section{$\underline{\text { TRITIUM }}$}

Brown, D. J. 1967. Migration Characteristics of Radionuclides Through Sediments Underlying the Hanford Reservation. ISO-SA-32.

Brown, D. J. and W. A. Haney. 1964. Chemical Effluents Technology Waste Disposal Investigations July-December, 1973 - The Movements of Contaminated Ground Water from the 200 Areas to the Columbia River. HW-80909.

Clayton, R. N., I. Friedman, D. L. Graaf, T. K. Mayeda, W. F. Meents and N. F. Shimp. 1966. The Origin of Saline Formation Waters. I. Isotopic Composition. J. Geophys. Res., 71, 3869-3882.

Corey, J. C. and J. W. Fenimore. 1968. Tracing Groundwater with Chloride Ions and Tritium Through Acid Kaolinitic Soil. Int. J. Appl. Rad. Isotopes. 19:741-746.

Halevy, E. 1964. The Exchangeability of Hydroxyl Groups in Kaolinite. Geochim. et Cosmochim. Acta. 28:1139-1145.

Haney, W. A. 1963. Fission Product Tritium in Fuel Reprocessing Wastes. HW-SA-3303.

Haney, W. A. 1964. Consequences of Activity Release. Nuclear Safety. $5: 399-403$.

Haney, W. A., D. J. Brown, and A. E. Reisenauer. 1962. Fission Product Tritium in Separations Wastes and in the Ground-Water. HW-74536.

Higgins, G. H. 1959. Evaluation of the Ground-Water Contamination Hazard from Underground Nuclear Explosions. J. Geophys. Res. 64:1509-1520.

Koranda, J. J. 1965. Preliminary Studies of the Persistence of Tritium and $14 \mathrm{C}$ in the Pacific Proving Ground. Health Phys., 11, 1445-1457.

Rabinowitz, D. D. 1969. Forced Exchange of Tritiated Water with Natural Clay. MS Thesis, N. Mex. Inst. of Min. and Tech., Socorro, NM.

Rabinowitz, D. D., C. R. Holmes and G. W. Gross. 1973. Forced Exchange of Tritiated Water with Clays. IN: Tritium, Messenger Graphics Pub., Phoenix and Las Vegas, 471-485.

Rosenqvist, I. T. 1963. Studies in Position and Mobility of the H Atoms in Hydrous Micas. IN: Clays and Clay Minerals, Monograph No. 13, p. 11-135, Macmi11an Co., NY.

Savin, A. M. 1967. 0xygen and Hydrogen Isotope Ratios in Sedimentary Rocks and Minerals. PhD Dissertation, Calif. Inst. of Tech. Pasadena, CA. 
Stewart, G. L. 1967. Fractionation of Tritium and Deuterium in Soi1 Water. IN: Isotope Techniques in the Hydrologic Cycle, Geophys. Monograph No. $11, \overline{159}-168$.

Teller, E., W. K. Talley and G. H. Higgins. 1968. The Constructive Uses of Nuclear Explosives. McGraw-Hi11, New York.

URANIUM

Baturin, G. N. 1971. Uranium in Solutions of 0oze Deposits in the Southeastern Atlantic. Dok1. Akad. Nauk. SSSR. 198:1186-1188 (in Russian).

Baturin, G. N. and A. V. Kochenov. 1973. Uranium in Interstitial Waters of Marine and Oceanic Sediments. Geokhimiya. No. 10:1529-1536 (in Russian).

Be11, K. G. 1960. Deposition of Uranium in Salt-Pan Basins. U.S.G.S. Professional Paper No. 354-G:161-169.

Breger, I. A., M. Deu1, and S. Rubinstein. 1955. Geochemistry and Mineralogy of a Uraniferous Lignite. Econ. Geol. 50:206-226.

Brown, J. H. and W. D. Keller. 1952. Uranium in the Clay of a Black Radioactive Shale. Science. 116:632-633.

Da11'Aglio, M. 1971. Study of the Circulation of Uranium in the Supergene Environment in the Italian Alpine Range. Geochim. et Cosmochim. Acta. $35: 47-59$.

Dorta, C. C. and E. Rona. 1971. Geochemistry of Uranium in the Cariaco Trench. Bul1. Mar. Sci. 21:754-765.

Ermolaev, N. P., A. P. Zhidikora, and V. A. Zarinski. 1965. On the Silicate Form of Uranium Transport in Aqueous Solutions. Geokhimiya No. 7:813-826 (in Russian).

Gabelman, J. W. 1971. Sedimentology and Uranium Prospecting. Sediment. Geol. 6:145-186.

Garrels, R. M. and C. L. Christ. 1965. Solutions, Minerals, and Equilibria. Harper and Row, New York.

Habashi, F. 1962. Correlation Between the Uranium Content of Marine Prosphates and 0ther Rock Constituents. Econ. Geol. 57:1081-1084.

Haglund, D. S. 1968. The Distribution of Uranium in Recent Carbonate Sediments and Skeletons of Organisms and the Effect of Diagenes is on Uranium Redistribution. Rensselaer Polytechnic Institute. Thesis. 
Haglund, D. S., G. M. Friedman, and D. S. Miller. 1969. The Effect of Freshwater on the Redistribution of Uranium in Carbonate Sediments. J. Sediment. Petrol. 39:1283-1296.

Kolodny, Y. 1969. Studies in Geochemistry of Uranium and Phosphorites. University of California. Thesis.

Kolodny, Y. and I. R. Kaplan. 1970. Deposition of Uranium in the Sediment and Interstitial Water of an Anoxic Fjord. CONF-700965-1.

Kovalevskii, A. L. 1967. Dependence of the Content of Some Trace Elements on the Clayiness of Soils. Mikroelem. Biosfere Ikh Primen. Scl. Khoz. Med. Sib. Dal'nego Vostoka, Dok1. Sib. Knof., 2nd. 1964. 0. V. Makew. Buryat. Khizhn. 1zd. Ulan-Ude, USSR.

Kuznetsov, Y. V., Z. N. Simonyak, A. P. Lisitsyn, and M. S. Frenklikh. 1968. Thorium Isotopes (230Th, 232Th) in the Surface Layer of the Indian Ocean Sediments. Geochem. Int. 5:169-177.

Latimer, W. M. 1952. The Oxidation States of the Elements and Their Potentials in Aqueous Solutions. Second Edition. Prentice-Hall, Inc., Englewood Cliffs, NJ.

Legin, V. K, Y. V. Kuznetsov and K. F. Lazarev. 1966. Uranium Occurrence in Marine Sediments. Geokhimiya No. 5:606-608 (in Russian).

Mizuno, A. and T. Mochizuki. 1970. Distribution of Uranium in the Sediments from San' in Off-Shore, Southwestern Japan. Chishitsu Chosasho Geppo. 21:287-292 (in Japanese).

Mo, T., A. D. Suttle, and W. M. Sackett. 1973. Uranium Concentrations in Marine Sediments. Geochim. et Cosmochim. Acta. 37:35-51.

Naumov, G. B. 1961. Some Physico-Chemical Peculiarities of Uranium Behavior in Hydrothermal Solutions. Geokhimiya. No. 2:115-132 (in Russian).

Palei, P. N. (comp.). 1962. Analytical Chemistry of Uranium. Trans. by N. Kaner. 1963. Israel Program for Scientific Translations Ltd. $421 \mathrm{p}$.

Ritchie, J. C., P. H. Hawks, and J. R. McHenry. 1972. Thorium, Uranium, and Potassium in Upper Cretaceous, Pateocene, and Eocene Sediments of the Little Tallahatchie River Watershed in Northern Mississippi. Southeast Geol. 14:221-231.

Sakanoue, M. 1960. Geochemical Studies on the Radioactive Sediments. III. Uranium, Phosphorus, and Arsenic in the Sedimentary Bed at Ningyo Pass. Nippon Kagaku Zasshi 81:898-902. 
Sillen, L. G. and A. E. Martell. 1964. Stability Constants of Metal Ion Complexes. Second ed. Spec. Publ. No. 17. The Chemical Society, London.

Udaltsova, N. I. 1963. General Information on Uranium. IN: Analytical Chemistry of Uranium. Israel Program for Scientific TransTations. pp. 3-7.

\section{ZIRCONIUM}

Baes, C. F., Jr. and R. F. Mesmer. 1976. The Hydrolysis of Cations. John Wiley and Sons, New York.

Bensen, D. W. 1960. Review of Soil Chemistry Research at Hanford. HW-67201.

Eichholz, G. G., T. F. Craft, and A. N. Galli. 1967. Trace Element Fractionation by Suspended Matter in Water. Geochim. et Cosmochim. Acta. $31: 737-745$.

Harrison, F. L. 1969. Radioactive Debris from Underground Nuclear Explosions: 1. Physical and Cherical Characteristics, 2. Biological Availability of the Radionuclides to Aquatic Animals. UCRL-50596.

Helgeson, H. C. 1969. Thermodynamics of hydrothermal systems at elevated temperatures and pressures. Am. J. Sci. 267:729-804.

Magno, P., T. Reavy, and J. Apidianakis. 1970. Liquid Waste Effluents from a Nuclear Fuel Reprocessing Plant. BRH-NERHL-70-2.

Rhodes, D. W. 1957. The Effect of $\mathrm{pH}$ on the Uptake of Radioactive Isotopes from Solution by a Soil. Soil. Soil Science Society America, Proceedings. 21:389-392.

Schulz, R. K. 1965. Soil Chemistry of Radionuclides. Health Physics. $11: 1317-1324$.

Sillen, L. G. and A. E. Marte11. 1964. Stability Constants of Meta1Ion Complexes. Special Publication No. 17. The Chemical Society, London.

Spitsyn, V. I., V. D. Balukova, A. F. Naumova, V. V. Gromov, F. M. Spiridonov, E. M. Vetrov, and G. I. Gravfov. 1958. A Study of the Migration of Radioelements in Soils. IN: Proc. Second Annual U.N. Conf. Peaceful Uses of Atomic Energy. 18:439-448.

Wagman, D. D., W. H. Evans, V. B. Parker, I. Halow, S. M. Bailey, R. H. Schumm. 1971. Selected Values of Chemical Thermodynamic Properties. U.S. Department of Commerce, N.B.S Technical Note 270-5. 
.

-

$+$

$-$

$\downarrow$

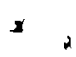




\section{DISTRIBUTION}

No. of

Copies

OFFSITE

A. A. Churm DOE Chicago Patent Group 9800 South Cass Avenue

Argonne, IL 60439

27 Technical Information Center

G. A. Kolstad

U.S.D.O.E.

Division of Basic Energy Research

Washington, DC 20545

W. C. Luth

U.S.D.O.E.

Division of Basic Energy Research

Washington, DC 20545

R. L. Watters

Division of Biomedical and Environmental Research

DOE

Washington, DC 20545

H. C. Claiborne

Office of Waste Isolation

P.0. Box $Y$

Building 9106

Oak Ridge, TN 37830

5 L. R. Dole

Office of Waste Isolation

P.0. Box $Y$

Building 9106

Oak Ridge, TN 37830

R. B. Laughon

Office of Waste Isolation

P.0. Box $Y$

Building 9106

Oak Ridge, TN 37830
No. of

Copies

W. C. McClain

Office of Waste Isolation

P.0. Box $Y$

Building 9106

Oak Ridge, TN 37830

C. D. Zerby

Office of Waste Isolation

P.0. Box $Y$

Building 9106

Oak Ridge, TN 37830

G. H. Jenks

Office of Waste Isolation

P.0. Box $Y$

Building 9106

Oak Ridge, TN 37830

C. W. Francis

Oak Ridge National Laboratory

P.0. Box $X$

Building 2001

Oak Ridge, TN 37830

J. A. Apps

Lawrence Berkeley Laboratory

University of California

Building 90, Room 2130

Berkeley, CA 94720

L. Benson

Lawrence Berkeley Laboratory

University of California

Building 90, Room 2130

Berkeley, CA 94720

L. D. Ramspott

Lawrence Livermore Laboratory

University of California

P.0. Box 808

Livermore, CA 94550 
PNL-2651

UC-70

No. of

Copies

D. G. Coles

Lawrence Livermore Laboratory

University of California

P.0. Box 808, Mail Code L-233

Livermore, CA 94550

G. A. Cowan

Los Alamos Scientific Laboratory

P.0. Box 1663

Los Alamos, NM 87545

D. Hoffman

Group CNC-11

Los Alamos Scientific Laboratory

Mai1 Stop 514

Los Alamos, NM 87545

M. Wheeler

Los Alamos Scientific Laboratory P.0. Box 1663

Los Alamos, NM 87545

M. Molecke

Sandia Laboratories

P.0. Box 5800

Albuquerque, NM 87115

R. B. Dosch

Sandia Laboratories

P. 0. Box 5800

Albuquerque, NM 87115

I. W. Marine

E. I. du Pont de Nemours Company

Savannah River Laboratory

Aiken, SC 29801

J. Cleveland

U.S. Geological Survey

Denver Federal Center

Mai1 Stop 412

P.0. Box 25046

Lakewood, CO 80225

G. D. DeBuchananne

U.S. Geological Survey

Reston, VA 22092
No. of

Copies

D. B. Stewart

U.S. Geological Survey National Center 959

Reston, VA 22092

D. M. Roy

217 Materials Research Laboratory

Pennsylvania State University University Park, PA 16802

G. McCarthy

217 Materials Research Laboratory

Pennsylvania State University

University Park, PA 16802

S. Fried

Argonne National Laboratory

9700 South Cass Avenue

Argonne, IL 60439

A. M. Friedman

Argonne National Laboratory

9700 South Cass Avenue

Argonne, IL 60439

M. G. Seitz

Argonne National Laboratory

9700 South Cass Avenue

Argonne, IL 60439

M. Steindler

Argonne National Laboratory

9700 South Cass Avenue

Argonne, IL 60439

R. B. Lantz

Intera Environmental Consultants

1201 Dairy Ashord, Suite 200

Houston, TX 77079

G. G. Eichholz

Regent's Professor of Nuclear Engineering

School of Nuclear Engineering Georgia Institute of Technology Atlanta, GA 30332 
PNL-2651

UC-70

No. of

Copies

D. Isherwood

Lawrence Livermore Laboratory

MS L-224

P.0. Box 808

Livermore, CA 94550

R. B. Leachman

U.S. Nuclear Regulatory Commission

Division of Fuel Cycle and

Material Safety

Washington, DC 20555

R. F. Kaufman

Evaluation Branch

Office of Radiation Programs

U.S.E.P.A.

P.0. Box 15027

Las Vegas, NM 89114

J. Shade

University of Toledo

Toledo, $\mathrm{OH} 43606$

J. Grant

Nuclear Engineering

9200 Shelbyville Road

Suite 526

Louisville, KY 40207

\section{FOREIGN}

J. Cherry

Department of Earth Sciences

University of Waterloo

Waterloo, Ontario

CANADA

Dr. B. Allard

Chalmers University of Technology

Fack

S-402 20 Goteborg 5

SWEDEN

K. Brodersen

Waste Management Station

Riso

4000 Roskilde

DENMARK
No. of

Copies

G. Collard

Department of Chemistry

S.C.K. C.E.N.

Boeretang 200

2400 MOL

Bel Givim

BELG IUM

Dr. D. Grey

Institute of Geologic

Sciences

Exhibition Road

S. Kensington

London, SW7-2DE

UNITED KINGDOM

R. B. Lyon

Atomic Energy of Canada, Ltd.

3 Lorne Place

Pinawa, Manitoba

CANADA

A. T. Jakubick

Nuclear Research Centre

7500 Karlsruhe

P.0. 3640

F. R. Germany

J. F. Pickens

Inland Waters Directorate

Hydrology Research Division

562 Booth Street

Ottawa, Ontario

CANADA KIA OET

Dr. F. P. Sargent

Atomic Energy of Canada Limited

Whiteshell Nuclear Research

Establishment

Pinawa, Manitoba

CANADA ROE $1 L 0$

\section{ONSITE}

DOE Richland Operations Office

0. J. Elgert 
No. of

Copies

J. A. Fernandez

R. B. Goranson

D. Squires

M. W. Tiernan

Battelle-Northwest

10 L. L. Ames

J. W. Bartlett

D. J. Bradley

3 H. C. Burkholder

D. B. Cearlock

G. W. Dawson

A. M. Platt

20 D. Rai

J. R. Raymond

A. E. Reisenauer

J. F. Relyea

20 R. J. Serne

J. A. Stottlemyre

J. F. Washburn

5 Technical Information Library

1 Technical Publications

Rockwell Hanford Operations

R. C. Arnett

G. S. Barney

R. A. Deju

M. Grutzeck

B. Richards

R. C. Routson

3 Rockwell Document Control

Boeing Computer

R. W. Nelson

$\underline{\text { UNI }}$

A. L. Cucchiara

A. P. Larrick

Westinghouse

R. B. Hall 